\title{
Melting Hanford LAW into Iron-Phosphate Glass in a CCIM
}

Nick Soelberg Sharna Rossberg

September 2011

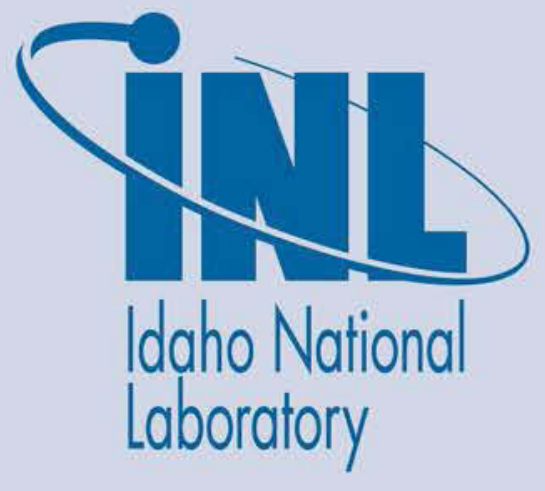

The INL is a U.S. Department of Energy National Laboratory operated by Battelle Energy Alliance 
INL/EXT-11-23251

\title{
Melting Handford LAW into Iron-Phosphate Glass in a CCIM
}

\author{
Nick Soelberg \\ Sharna Rossberg
}

September 2011

\begin{abstract}
Idaho National Laboratory
Idaho Falls, Idaho 83415
\end{abstract}

http://www.inl.gov

Prepared for the

U.S. Department of Energy

Assistant Secretary for Environmental Management

Under DOE Idaho Operations Office

Contract DE-AC07-05ID14517 
This page is intentionally blank 


\section{SUMMARY}

A test has been conducted to demonstrate the vitrification of a Hanford low activity waste (LAW) that contains relatively large amounts of sulfate and sodium, compared to other radioactive Hanford waste streams, in an iron-phosphate waste form, using a cold crucible induction melter (CCIM). The high sulfate content limits the potential loading of this waste stream in conventional borosilicate glass. This test showed that the waste loading could be increased to at least $26 \mathrm{wt} \%$ waste oxides in the glass, which is 4-8 times higher than the waste loading achievable for this waste stream in borosilicate glass.

This test program was performed by a multi-laboratory, international, and multi-disciplinary team under the direction of the US Department of Energy (DOE) Office of Environmental Management-31 (EM-31) Task WP-4.1.3, "Next Generation Induction-heated and Advanced Joule-heated Melter Bench Scale Testing." An advanced joule-heated melter (JHM) test was conducted in parallel, also under DOE EM-31, Task WP-4.1.3 direction, using the same iron phosphate waste formulation (reported by Pacific Northwest National Laboratory in a separate report).

The CCIM test program was performed to generate data necessary for preliminary design of induction-heated melters along with evaluation of the suitability of the melter for this waste type and glass formulation. The test did not include use of radioactive feed materials or radioactive tracers, and does not provide design data for an actual radioactive waste vitrification system.

Two test conditions were performed per the test plan:

1. Nominal $1,030^{\circ} \mathrm{C}$ melt temperature, feedrate of $0.86 \mathrm{~L} / \mathrm{hr}(1.4 \mathrm{~kg} / \mathrm{hr})$, and nearly complete cold cap coverage, with a glass production rate of $0.66 \mathrm{~kg} / \mathrm{hr}$.

2. Nominal $1,100^{\circ} \mathrm{C}$ melt temperature, melter feed slurry feedrate of $2.0 \mathrm{~L} / \mathrm{hr}(3.2 \mathrm{~kg} / \mathrm{hr})$, a more complete cold cap was accomplished because of the higher feed rate, and the glass production rate was $1.5 \mathrm{~kg} / \mathrm{hr}$.

Induction power levels ranged up to about $40 \mathrm{~kW}$. Cold cap coverage ranging between $60-75 \%$. Higher cold cap coverages that occur at higher feedrates tended to cause some bridging inside this relatively small-diameter crucible, especially with the bubbler and thermocouple that penetrated through the cold cap.

Specific feedrates ranging between about $600-1,400 \mathrm{~kg} / \mathrm{m}^{2} /$ day (specific glass production rates ranging between about $300-600 \mathrm{~kg} / \mathrm{m}^{2} /$ day. Higher feedrates are expected to be possible in largerdiameter crucibles that have larger distances between the crucible wall and equipment such as melt thermocouples and bubblers that reduce bridging tendencies.

The melter off-gas composition was diluted somewhat (up to about $1.7 \mathrm{x}$ ) by the air bubbler and air inleakage. The melter off-gas was mostly $(50-70 \%)$ water vapor, $6-9 \% \mathrm{O}_{2}, 2-5 \% \mathrm{CO}_{2}$, under $0.5 \% \mathrm{H}_{2}$, around 1,000 ppm $\mathrm{NO}_{\mathrm{x}}$, low-ppm levels of $\mathrm{CO}, \mathrm{CH}_{4}$, and $\mathrm{SO}_{2}$, and balance nitrogen. Off-gas flammability was not a significant concern.

While the melter feed was continuous during the test, glass draining was semi-continuous, performed for short durations of typically 5-10 minutes when the melt level was high enough. The product glass typically had a nearly-black, obsidian-like look, and broke into typical sharp fragments when fast-cooled. The surfaces were shiny; the surfaces of broken fragments were more shiny than the surfaces of unbroken pancake pieces.

The product glass consisted of major constituents $\left(\sim 39 \% \mathrm{P}_{2} \mathrm{O}_{5}, \sim 20 \% \mathrm{Na}_{2} \mathrm{O}, \sim 13 \% \mathrm{Al}_{2} \mathrm{O}_{3}, \sim 7 \%\right.$ $\mathrm{Fe}_{2} \mathrm{O}_{3}$, and $\sim 6 \% \mathrm{SiO}_{2}$ ) and lesser amounts of other key constituents, including over $3 \% \mathrm{SO}_{3}$. The glass was mostly oxidized, with an average $\mathrm{Fe}^{+2} / \mathrm{Fe}_{\text {total }}$ ratio of 0.08 , due in part to the use of an air bubbler to 
agitate and mix the melt. Sucrose sugar was added to the melter feed that was about $1 / 2$ of the amount needed to reduce the nitrates and nitrites in feed to $\mathrm{N}_{2}$. The glass density averaged $2.80 \mathrm{~g} / \mathrm{cc}$.

The product glass durability was measured using the Product Consistency Test (PCT) and Vapor Hydration Test (VHT) on as-received (fast-cooled) samples and on samples that were re-melted and then slow-cooled according to a controlled centerline cooling (CCC) profile. The normalized PCT release rates for $\mathrm{Na}$ and $\mathrm{Si}$ were within the DOE limit for LAW. The normalized release rate for $\mathrm{B}$ exceeded the DOE limit; but the concentration of B was very low in this product glass because B is present in only trace amounts in the waste simulant, and is not a component of the glass forming chemicals; so the B normalized mass release rate is not a good indicator of durability for this glass. While the VHT corrosion rate for the CCC samples was higher than for the as-received samples, the corrosion rates for both the asreceived and the CCC samples were less than the DOE limit for LAW.

$\mathrm{X}$-ray diffraction (XRD) analyses were performed on as-received product glass samples. Several crystalline phases were found in small amounts. The largest crystalline phase was $\mathrm{CaF}_{2}$. Smaller crystalline phases included $\mathrm{Cr}_{2} \mathrm{O}_{3}$, chromium iron oxide, nosean, sodium phosphate, sodium iron oxide, calcium phosphate, and sodalite.

Mass balances show that generally good mass balance closure was achieved. Most of the elements in the feed had mass balance closure (output mass divided by input mass) of 0.8 to 1.2 , a reasonable range considering experimental error. The mass balance closure of the total glass is even better, at 1.03.

Elements that had mass balance closure outside of the 0.8-1.2 range were $\mathrm{Re}, \mathrm{S}$, and $\mathrm{Zr}$. The concentrations of $\mathrm{Re}$ and $\mathrm{Zr}$ were relatively small, so experimental errors may have been relatively large compared to the same errors for elements present in larger amounts. The sulfur mass balance closure, at about 0.76 , was just outside of the 0.8 to 1.2 range. The low $\mathrm{S}$ mass balance closure may have been due in part to the ability of $\mathrm{S}$ to form various other species that were not detected in the offgas analyses.

Elemental partitioning between the glass product and the off-gas can be calculated at least three different ways when composition and mass data is available for all of the input and output streams. The average partitioning of Cs to the offgas was a relatively low 3.9-4.6\% depending on the method used. Partitioning of S to the off-gas was also moderately low at 10-32\%, depending on the method used. About $36 \%$ of the Re partitioned to the offgas. Very little of the $\mathrm{P}(0.07 \%)$ partitioned to the off-gas. These results are generally consistent with expectations for known volatile and less volatile elements at the relatively moderate vitrification temperatures less than $1,100^{\circ} \mathrm{C}$.

Future iron-phosphate CCIM vitrification studies might include these possible activities:

- Longer-duration testing in a larger-diameter crucible to demonstrate higher potential feedrates by using freeboard heating, or a larger-diameter crucible with less bridging that occurs in a smallerdiameter crucible

- Additional off-gas analyses to assess such features as in-melter $\mathrm{NO}_{\mathrm{x}}$ destruction and $\mathrm{S}$ speciation

- Potential further increases in waste loading

- Additional S partitioning analyses to better narrow the $10-32 \%$ range of S partitioning to the offgas observed this test

- Investigation of melt temperature and control methods including more corrosion-resistant thermocouples and models that relate melt temperature to induction power conditions

- Other challenging waste streams. 


\section{ACKNOWLEDGEMENTS}

The authors thank the many contributors to the success of this CCIM test. This test was one of several components of the US Department of Energy (DOE) Office of Environmental Management-31 (EM-31) Task WP-4.1.3, "Next Generation Induction-heated and Advanced Joule-heated Melter Bench Scale Testing." Project oversight and coordination with other components of the Next Generation Melters program was provided by guided by Gary Smith of Office of Waste Processing, EM-31 Technology Innovation \& Development, Jay Roach of (formerly) Idaho National Laboratory, John Vienna of Pacific Northwest National Laboratory, and David Peeler of Savannah River National Laboratory. Valuable consultation was provided by Catherine Veyer of SGN and Eric Tchemitcheff of AREVA Federal Services (AFS). Other AREVA, CEA, and SGN personnel who helped include Christophe Girold, Eric Chauvin, Joe Buchanon, and Anthony Prod'Homme.

Glass formulation testing was performed at Missouri University of Science and Technology and MOSCI Corporation. This work, performed by Delbert Day, CW Kim, Dick Brow, Chandra Ray, and others there determined the composition and waste loading of the iron-phosphate glass, and properties of the molten glass needed to determine suitable CCIM power and melting conditions.

Pre-test preparations and development of the waste simulant and melter feed were aided by work performed by Erich Hansen and David Peeler at SRNL.

The CCIM test team included Mike Ancho, Kip Archibald, Sabrina Morgan of the INL; John Richardson of VISTA Engineering; and John Yadon, Ervin Brubaker, and Lewis Ware of Y7 Consulting. Many thanks to these persons for the long and sometimes unusual work hours.

Post-test sample analyses were provided by PNNL (coordinated by Gary Sevigny and Mike Schweiger), SRNL (coordinated by Fabienne Johnson), and MS\&T and MO-SCI (coordinated by Delbert Day, Dick Brow, and CW Kim), and TestAmerica (coordinated by Robert Weidenfeld). 
This page is intentionally blank 


\section{CONTENTS}

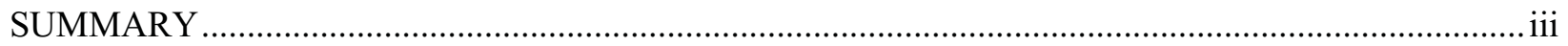

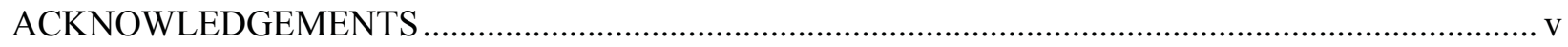

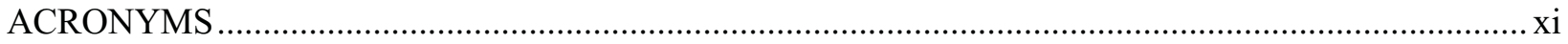

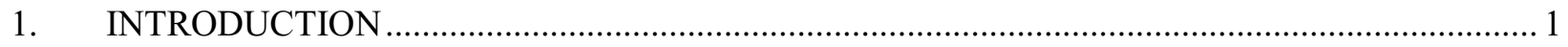

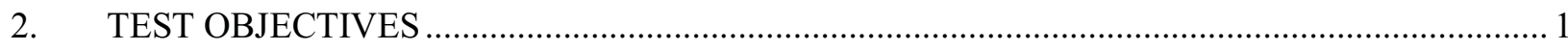

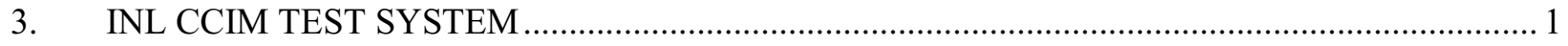

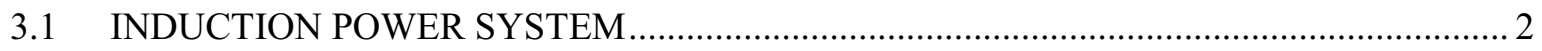

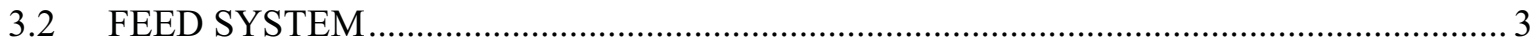

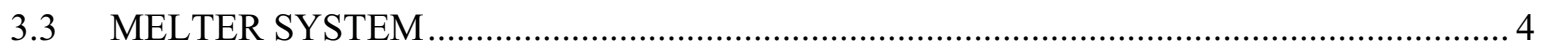

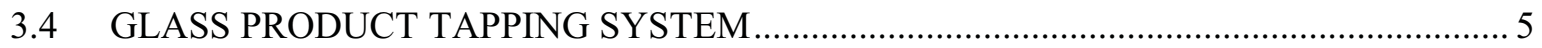

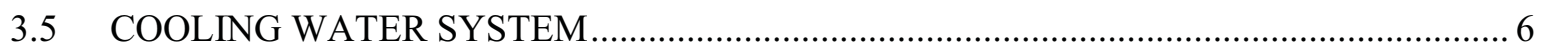

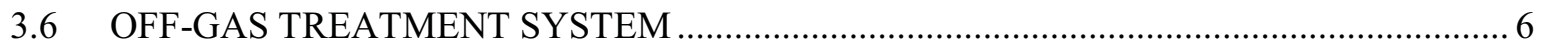

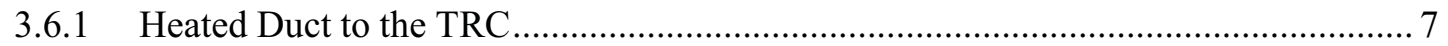

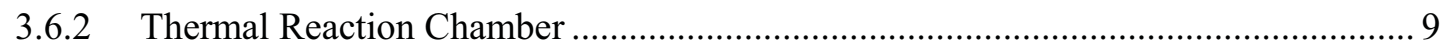

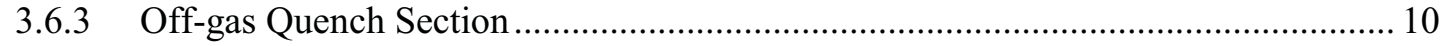

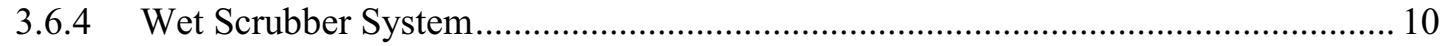

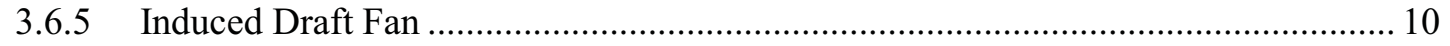

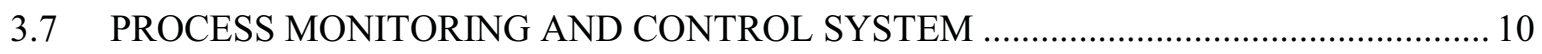

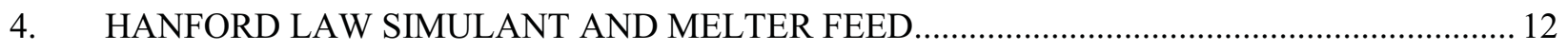

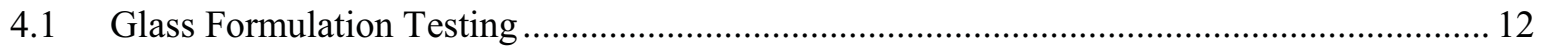

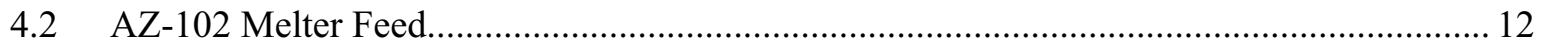

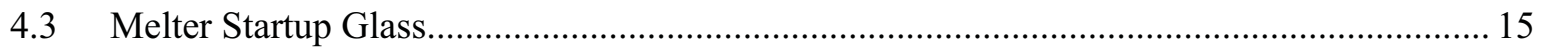

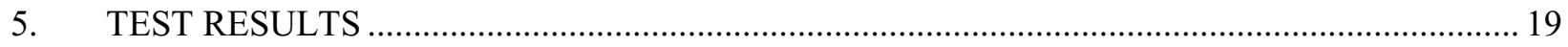

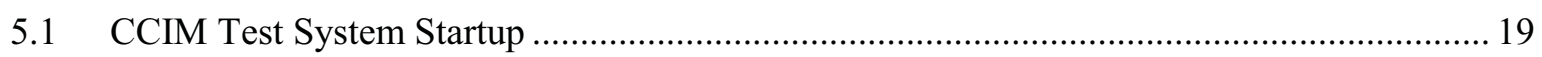

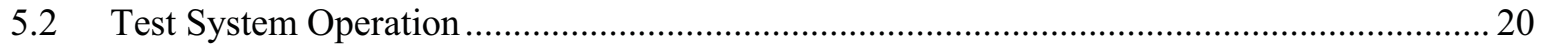

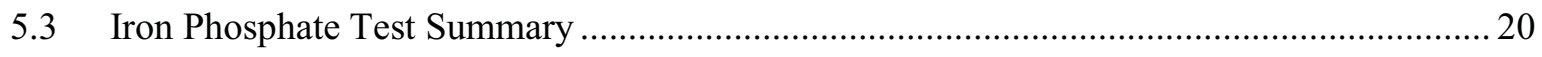

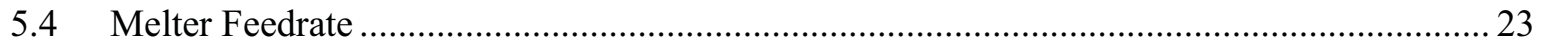

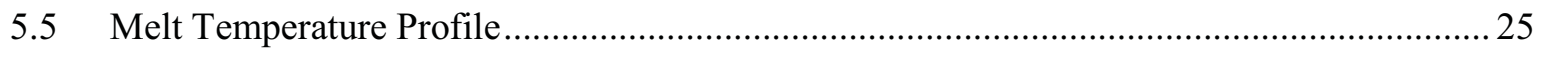

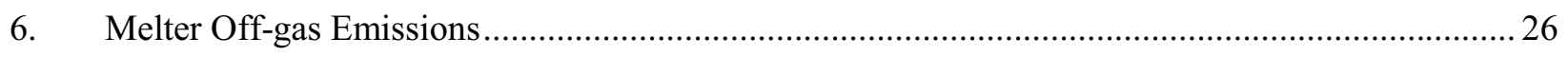

6.1 Melter Off-gas Composition and Flowrate …............................................................. 26

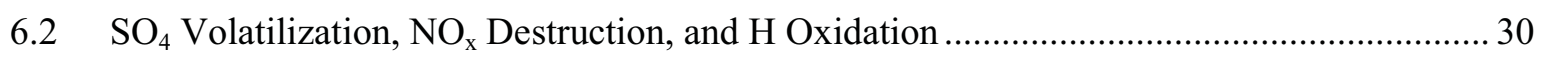

6.3 Melter Off-gas Particulate and Metals Emissions ............................................................... 30

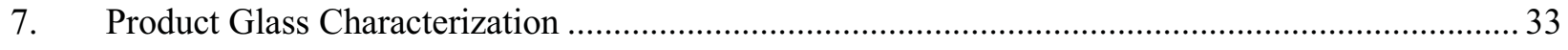

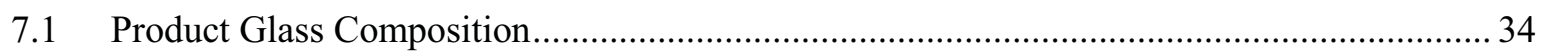




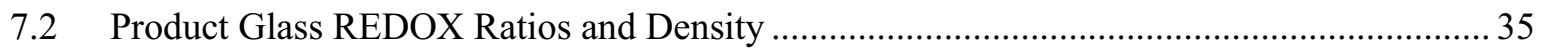

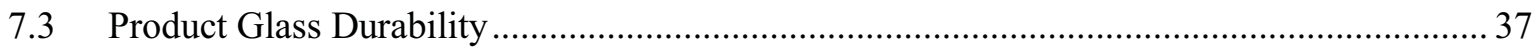

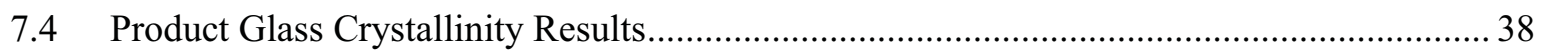

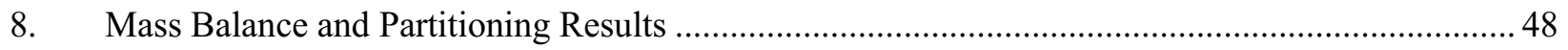

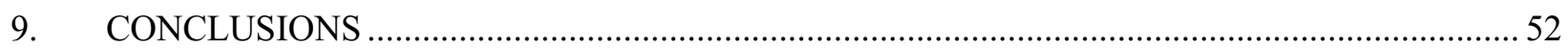

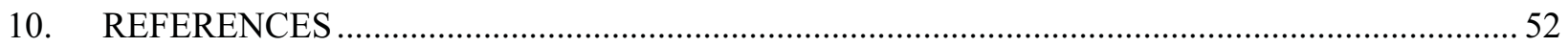

TABLES

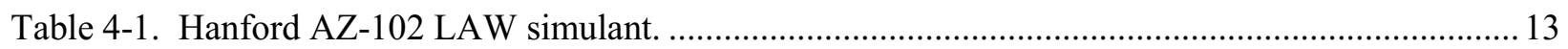

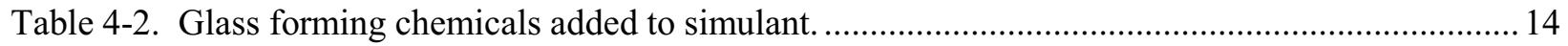

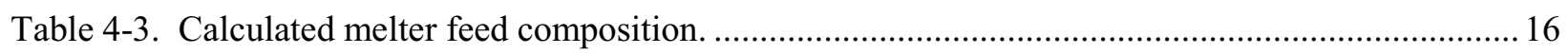

Table 4-4. Final melter feed composition accounting for water dilution and sugar addition................... 17

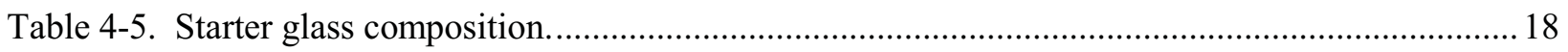

Table 5-1. Average operating conditions for each test condition during the iron phosphate test............. 22

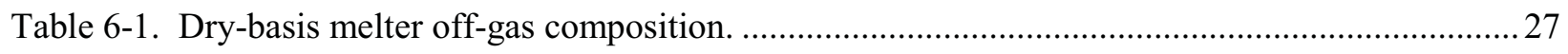

Table 6-2. Wet-basis melter off-gas flowrate and composition...........................................................2 27

Table 6-3. Melter off-gas particulate and metals concentrations and emission rates..............................31

Table 6-4. Analysis of the off-gas scrub solution following the test.................................................... $31 \underline{2}$

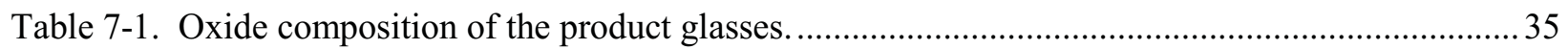

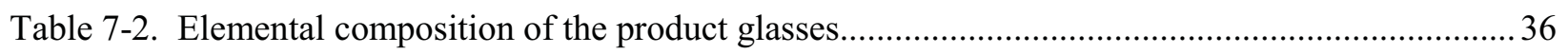

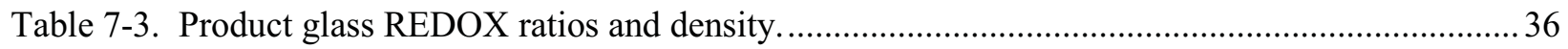

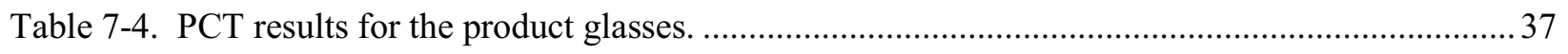

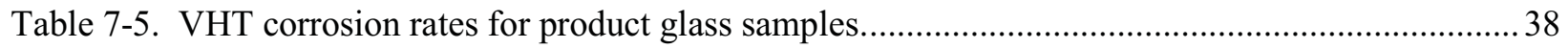

Table 8-1. Input and output total and elemental mass balances compositions for the test (part 1)...........49

\section{FIGURES}

Figure 3-1. Simplified process schematic of the INL CCIM test system. ............................................. 2

Figure 3-1. Simplified process schematic of the INL CCIM test system. .............................................. 2

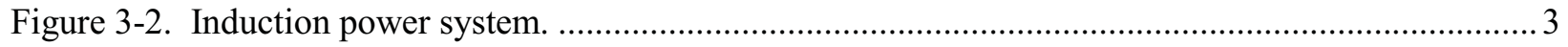

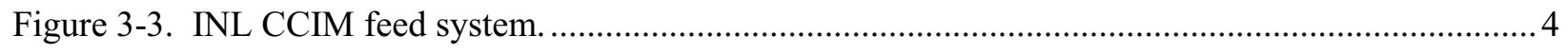

Figure 3-4. INL CCIM generator cooling water system schematic.................................................... 7 
Figure 3-5. INL CCIM crucible cooling water system schematic. ................................................ 8

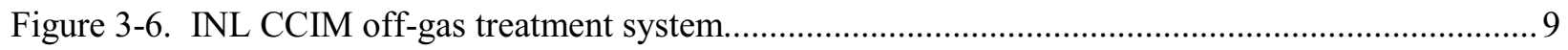

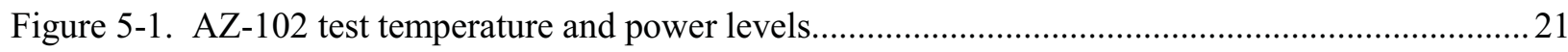

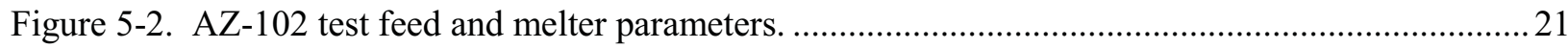

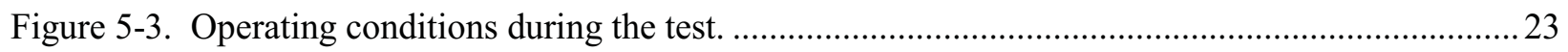

Figure 5-4. View of the partially-covered melt surface through a site port on the melter lid..................23

Figure 5-5. Specific feedrate and melter freeboard temperatures at different cold cap coverages............24

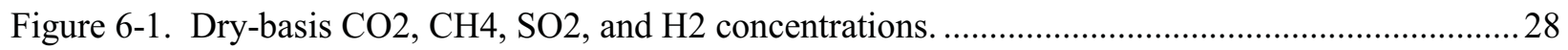

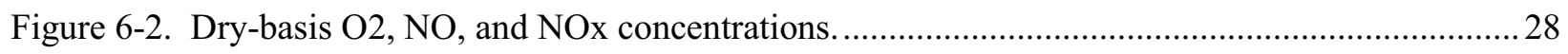

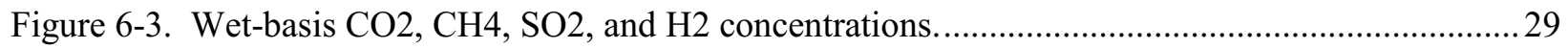

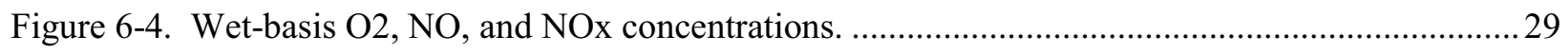

Figure 7-1. Molten glass draining from the melter through the bottom drain. ....................................... 33

Figure 7-2. Examples of glass samples collected for archiving or analysis in a stainless steel pan, a smaller stainless steel sample cup, or fritted into water and then dried................................. 34

Figure 7-3. XRD scan for sample 1057A, drain 3 frit sample (fast-quenched glass).............................39

Figure 7-4. XRD scan for sample 1052A, drain 4 fritted sample (fast-quenched glass). ....................... 40

Figure 7-5. XRD scan for sample 1056A, drain 4 cup sample (fast-cooled but not quenched

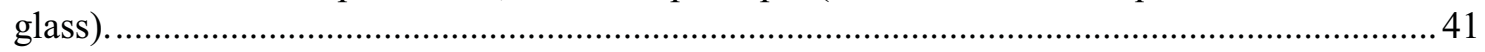

Figure 7-6. XRD scan for sample 1060A, drain 5 fritted sample (fast-quenched glass). ....................... 42

Figure 7-7. XRD scan for sample 1058A, drain 5 cup sample (fast-cooled but not quenched

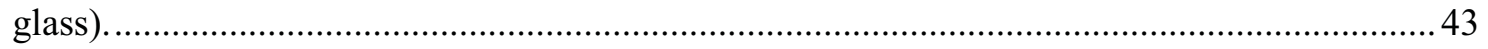

Figure 7-8. XRD scan for sample 1070A, drain 8 fritted sample (fast-quenched glass)....................... 44

Figure 7-9. XRD scan for sample 1069A, drain 8 cup sample (fast-cooled but not quenched

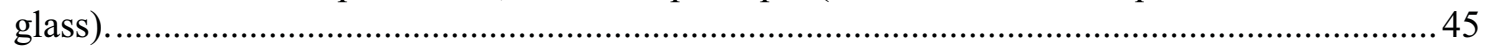

Figure 7-10. XRD scan for sample 1072A, drain 9 fritted sample (fast-quenched glass). ......................46

Figure 7-11. XRD scan for sample 1073A, drain 9 cup sample (fast-cooled but not quenched

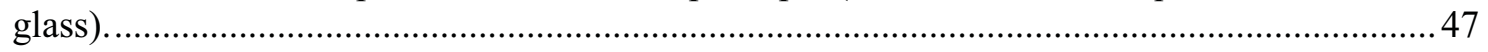

Figure 8-1. Elemental mass balance closure for the test................................................................. 51

Figure 8-2. Elemental partitioning to off-gas particulate matter for the test..........................................51 
This page is intentionally blank 


\section{ACRONYMS}

CCC controlled-centerline-cooling

CCIM cold crucible induction melter

CEA Commissariat à l'Energie Atomique

CEMS continuous emissions monitoring system

DACS data acquisition and control system

DL detection limit

DOE Department of Energy

EM-31 Environmental Management-31

EPA Enviromnental Protection Agency

GFC glass forming chemical

JHM Joule heated melter

ICP-AES Inductively-coupled plasma atomic absorption spectrometry

ICP-MS Inductively-coupled plasma mass spectrometry

ID induced draft

IEDF INL Engineering Demonstration Facility

INL Idaho National Laboratory

LAW low activity waste

MO-SCI MO-SCI Corporation

MS\&T Missouri University of Science and Technology

MTEC Maximum Theoretical Emission Concentration

NAS National Academy of Sciences

P\&ID process and instrumentation diagram

PCT Product Consistency Test

PIC product of incomplete combustion

PM particulate matter

PNNL Pacific Northwest National Laboratory

REDOX iron reduction/oxidation ratio

$\mathrm{RF} \quad$ radio frequency

SRNL Savannah River National Laboratory

TC thermocouple

THC total hydrocarbon

TRC thermal reaction chamber

UDS undissolved solids 


$\begin{array}{ll}\text { VHT } & \text { Vapor Hydration Test } \\ \text { VOC } & \text { volatile organic compound } \\ \text { WESP } & \text { wet electrostatic precipitator } \\ \text { WP } & \text { waste processing } \\ \text { XRD } & \text { x-ray diffraction } \\ \text { XRF } & \text { x-ray fluorescence }\end{array}$




\section{Melting Hanford LAW into Iron-Phosphate Glass in a CCIM}

\section{INTRODUCTION}

A vitrification test has been conducted using the cold crucible induction melter (CCIM) test system at the Idaho National Laboratory (INL). The test was conducted to demonstrate the vitrification of a Hanford low activity waste (LAW) that contains relatively large amounts of sulfate and sodium, compared to other radioactive Hanford waste streams. The high sulfate content limits the potential loading of this waste stream in conventional borosilicate glass, so this test demonstrated how this waste stream could be vitrified in an iron-phosphate glass that can tolerate higher levels of sulfate.

This test was conducted under the US Department of Energy (DOE) Office of Environmental Management-31 (EM-31) Task WP-4.1.3, "Next Generation Induction-heated and Advanced Joule-heated Melter Bench Scale Testing." The Waste Processing (WP) designation is from the National Academy of Sciences (NAS) report “Advice on the Department of Energy's Cleanup Technology Roadmap - Gaps and Bridges" (NAS 2009).

This CCIM test was performed in parallel with advanced JHM testing, which is also funded by EM31. The INL, AREVA Federal Services, and le Commissariat à l'Energie Atomique (CEA) work on this CCIM test program is funded and managed through WP-4.1.3, WP-4.1.4 ("Next Generation Melter Development and Engineering"), and WP-5.1.1 ("Phosphate Glass Development and Demonstration"). Missouri University of Science and Technology (MS\&T) provided a target glass formulation for the tests under WP-4.1.2 "Glass Formulation for Next Generation Melters."

The test objectives are summarized in the following section. Section 3 describes the CCIM test system. Section 4 describes the waste simulant, summarizes the glass formulation testing performed by Missouri University of Science and Technology (MS\&T) and MO-SCI Corporation, and the melter feed that contained the waste simulant, glass forming chemicals, and sugar added for melt rate enhancement. Sections 5-8 contain the test results.

\section{TEST OBJECTIVES}

The CCIM test was performed to meet objectives of Task WP-4.1.3 "Next Generation Inductionheated and Advanced Joule-heated Melter Bench Scale Testing." Testing was performed to generate data necessary for preliminary design of induction-heated melters along with evaluation of the suitability of the melter for this waste type and glass formulation. The type of questions to be answered include the range of component volatility, preliminary glass waste loading and melting rates for sizing calculations, compatibility of off-gas treatment components, corrosion of materials of construction from more aggressive glass chemistries, etc.

The CCIM test did not include use of radioactive feed materials or radioactive tracers, and does not provide design data for an actual radioactive waste vitrification system.

\section{INL CCIM TEST SYSTEM}

The INL CCIM test system (Figure 3-1) is a fully integrated assembly of several different subsystems including solid and liquid/slurry feed systems, the melter system, cooling systems, and a complete off-gas treatment system designed to comply with the most rigorous air emission regulatory requirements. The CCIM test system includes sampling access and monitoring capabilities to measure and characterize off- 
gas emissions. The off-gas system that can destroy $\mathrm{NO}_{\mathrm{x}}$ and flammable gas emissions and scrub acid gases and particulate matter. It provides the capability to generate data to determine how the feed constituents partition throughout the system. The test system includes the following subsystems:

- Induction power system

- Feed system

- Melter system

- Glass product tapping system

- Cooling water system

- Off-gas control system

- Process monitoring and control system

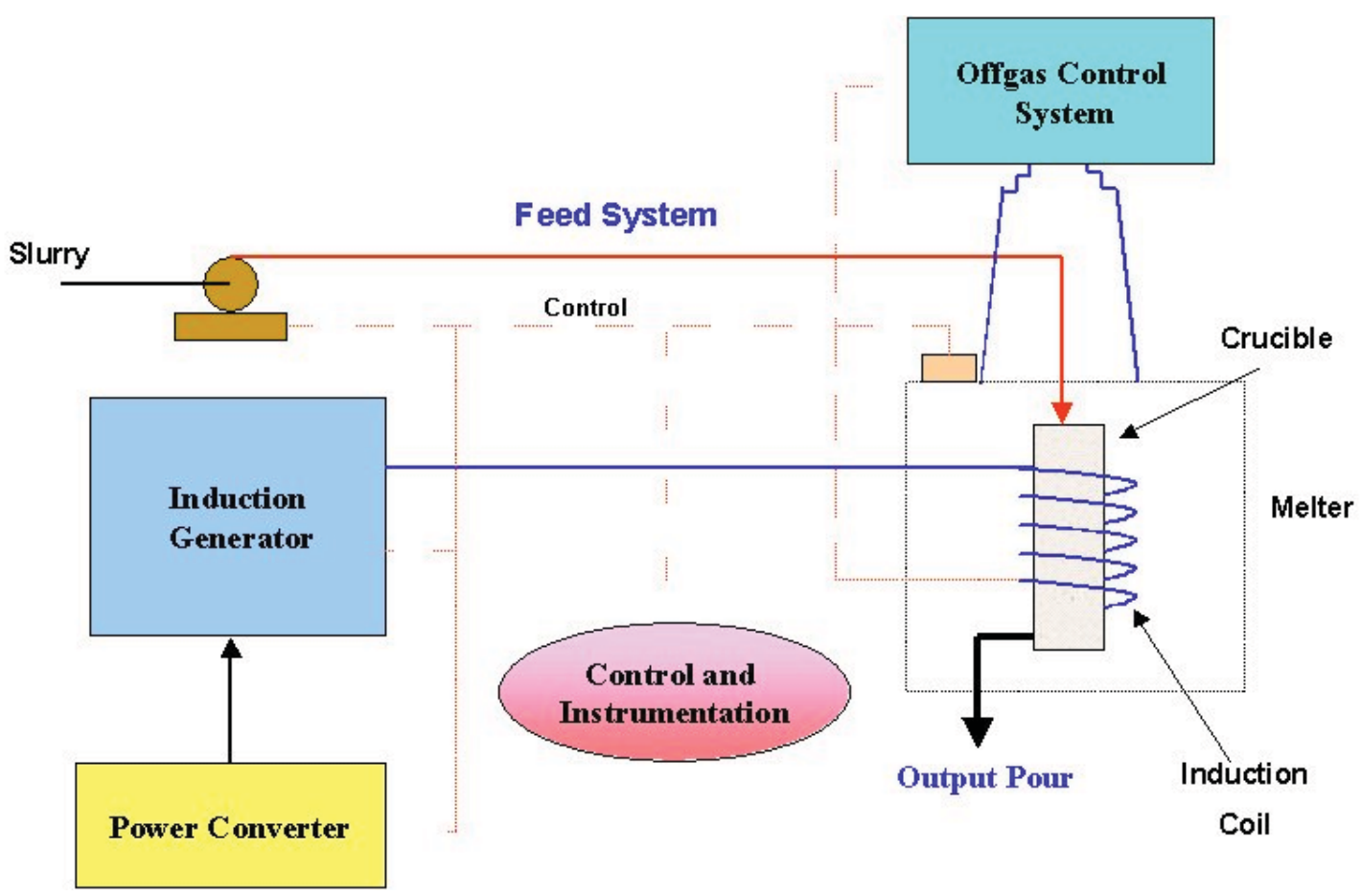

Figure 3-1. Simplified process schematic of the INL CCIM test system.

\subsection{INDUCTION POWER SYSTEM}

Major components of the induction power system (Figure 3-2) include a Taylor-Winfield Thermionic C-6000 radio frequency (RF) generator, a coil transfer relay, and the induction coil. The frequency generator itself consists of three subsystems - an enclosed plate transformer unit, a high frequency generator chassis, and a control workstation. The enclosed transformer receives $480 \mathrm{~V}$ input power from the INL Engineering Demonstration Facility (IEDF) and supplies nominal 15-kV, 3-phase power to the generator chassis. The $15 \mathrm{kV}$ transformer output, which is rectified with a 3-phase, full-wave bridge in the chassis, is subsequently filtered to provide low-ripple direct current to the triode oscillator. Varying the angle of the firing system allows programming the plate voltage to the triodes, thus controlling output power. 
The induction power system provides induction power of up to $60 \mathrm{~kW}$. The power level is adjustable via the control panel over the range of $15-40 \mathrm{~kW}$. The generator can also be configured to provide full power at a single frequency over a frequency range of $200-400 \mathrm{kHz}$ and $1.5-4 \mathrm{MHz}$. The maximum design power output is $75 \mathrm{~kW}$, but overpower interlocks limit the maximum power to $60 \mathrm{kWe}$ without readjustment.

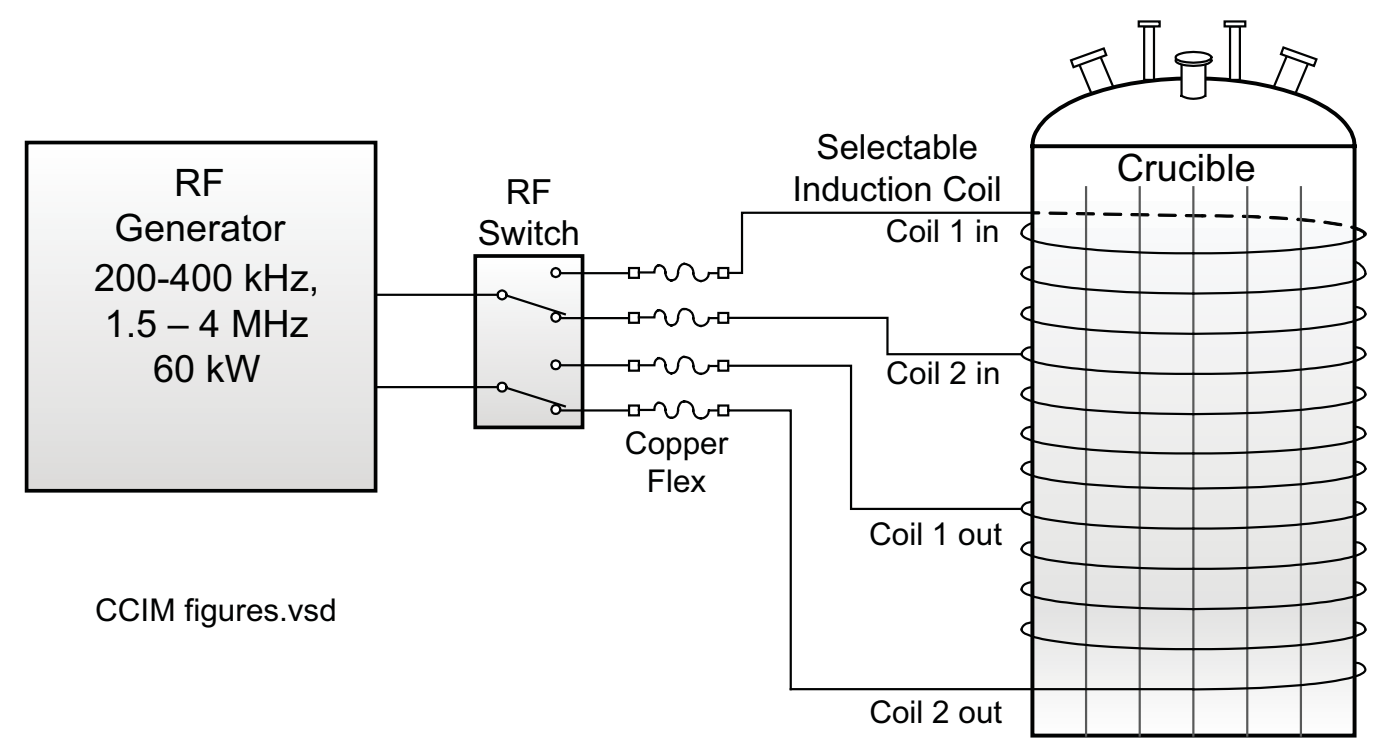

Figure 3-2. Induction power system.

A conductive metal cage encloses the melter and induction coil system, to ensure that workers are not exposed to unsafe levels of electromagnetic radiation, to prevent worker or equipment contact with high energy electrical conductors, and to protect the melter and induction coil equipment. Worker exposure to electromagnetic radiation is regulated by ANSI/IEEE Standard C95.1, "Standard for Safety Levels with Respect to Human Exposure to Radio Frequency Electromagnetic Fields, $3 \mathrm{KHz}$ to $300 \mathrm{GHz}$."

Operating parameters within the power supply system are continuously monitored. If certain conditions exceed preset safe values, the power supply system is automatically shut down. In addition, multiple and redundant safety interlocks are provided to protect operators.

\subsection{FEED SYSTEM}

The test system includes feed systems for delivering liquid, slurry, or solid granular or powdered materials. The liquid/slurry feed system shown in Figure 3-3 includes two feed tanks for mixing and feeding liquids or slurries. Each feed tank is equipped with a stirrer, sparger, and recirculation loop to maintain homogeneity in slurry feed mixtures. A recirculation pump draws feed solution from the feed tank and recycles it back to the feed tank, which improves mixing in the feed tank. A separate metering pump provides melter feed flow metering and control. The melter feed pump can draw feed from the pressurized output of either recirculation pump, or directly from either feed tank. For this test, the melter feed was drawn directly from the feed tank in operation at the time, to reduce the potential that undissolved particles in the slurry might be size or density-segregated if the melter feed pump used a slipstream of the recirculation pump flow.

The feed system is designed with the capability to feed water during startup and shutdown, and for flushing the feed system with water or compressed air to clear it of potential plugging from undissolved solids (UDS) or glass frit in the feed slurry. 
Feeds are deposited near the center of the crucible, on top of the melt. Three viewports enable visual and camera observation of the deposition of the feed on the melt surface.

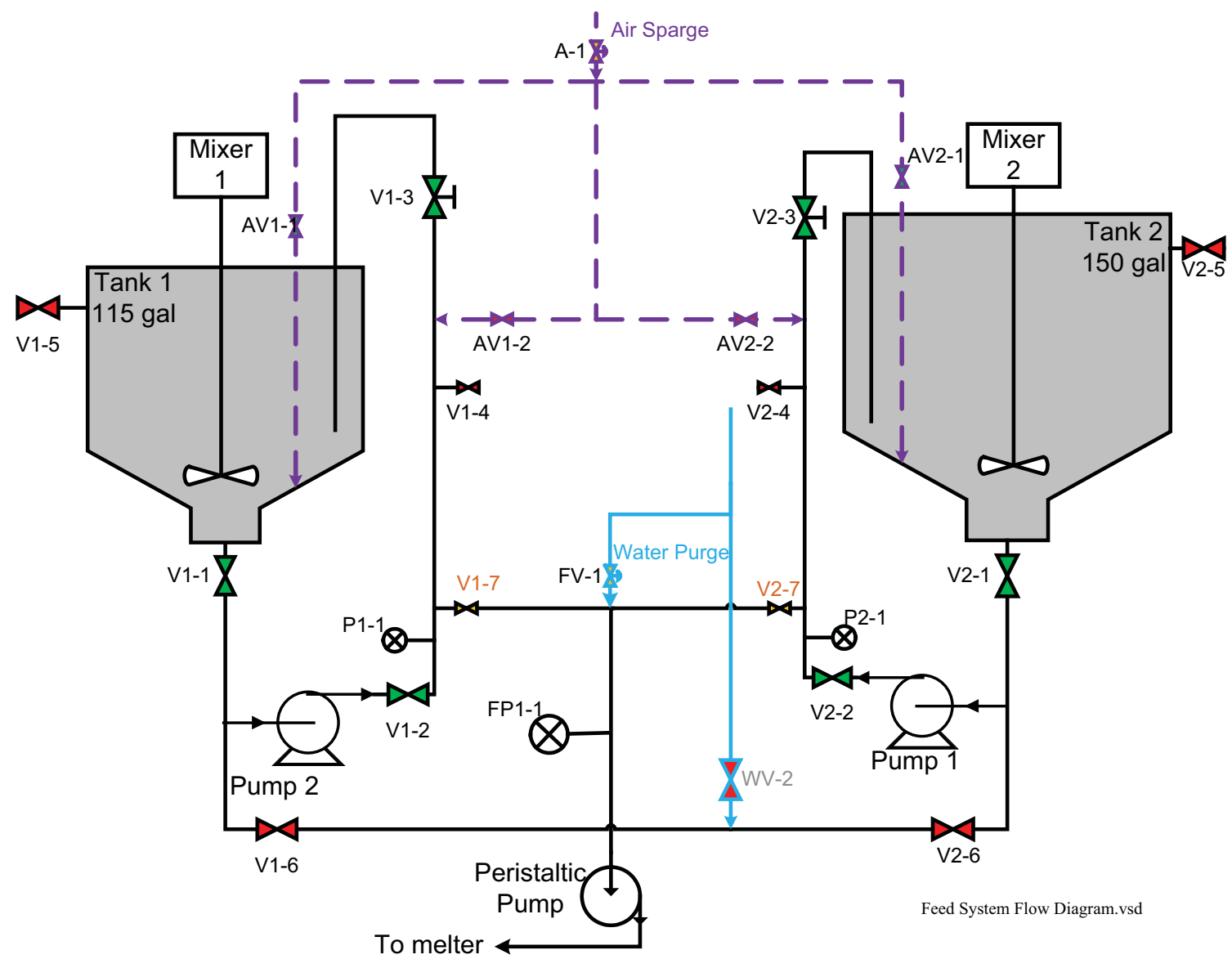

Figure 3-3. INL CCIM feed system.

\subsection{MELTER SYSTEM}

The melter crucible contains the molten melt material. It is constructed of 304L stainless steel, and consists of three primary components: the lower manifold, the upper manifold, and the cooling tubes. The crucible wall consists of vertical water-cooled tubes oriented to form a crucible cylinder with a nominal $26.7 \mathrm{~cm}$ (10.5 inches) internal diameter. The overall crucible height is $40.6 \mathrm{~cm}$ (16 inches).

During operation, the water-cooled tubes cause glass adjacent to the tubes to solidify into a solid skull wall that forms the crucible enclosure, while maintaining appropriate temperatures in the crucible walls. The crucible water cooling system can provide adequate cooling at the nominal full generator power $(60 \mathrm{~kW})$ and with a glass temperature up to $2,000^{\circ} \mathrm{C}$.

Liquid and solid feeds are fed to the top of the molten melt inside the melter crucible, using tubes that penetrate through the melter lid. Only a liquid slurry feed was used in this test. Fragmented glass frit used at initial startup was added manually. 
Melter startup is achieved using a conductive graphite ring placed in the startup glass frit, which coupled with the induction field. Resistance heating in the graphite ring heated the startup glass until it melted, at which time the molten glass was conductive enough to also couple with the induction field, until it was fully molten. After a short time (a few hours) with the air bubbler operating in the molten glass, prior tests have shown that the graphite ring is oxidized to $\mathrm{CO}$ and $\mathrm{CO}_{2}$ gas, and does not persist in the molten glass melt.

When the feed slurry is started, the feed is heated and melted via heat transfer from the molten bath, which in turn is inductively heated by the electrical induction field. As the water in the slurry feed is evaporated, reactions occur between reductants and oxidants in the feed, and the dried residues heat to melt temperatures and become incorporated into the melt. New fresh feed is continuously or semicontinuously fed. During this test, the feed was continuous except for a few short periods when the feed was turned off.

Available lid penetrations are as follows:

- Three view ports used for visual and camera observations of the glass melt.

- One vertical port used as the slurry feed port.

- One port used for glass melt temperature measurements.

- One port used for the air bubbler. The target air bubbler rate, to best emulate the operation of the CEA Marcoule CCIM, was 1-1.5 lpm (Girold 2008).

- One side port used for sampling melter freeboard gas and for a thermal radiation-shielded melter freeboard gas temperature measurement.

The crucible lid consists of an internal inconel shell that encloses the crucible freeboard space, which is covered with an outer stainless steel shell. The internal space between the inner and outer shells of the lid can be air or steam-cooled, or uncooled. Water cooling was not used here, as it would cause the lid to be too cool and cause condensation and deposition of material inside the lid during operation. No active cooling was used during this test.

The melt height inside the crucible varies as the feed is continuously fed and the glass is semicontinuously tapped. The melt height can range between $10.2-30.5 \mathrm{~cm}(4-12$ inches $)$, but the nominal design height is $26.7 \mathrm{~cm}$ (10.5 inches), equal to the melt diameter. The freeboard volume above the nominal melt height inside the crucible is $7,800 \mathrm{~cm}^{3}\left(476 \mathrm{in}^{3}\right)$. The melter lid, which is the same diameter and $15 \mathrm{~cm}$ (5 inches) high, adds $7,090 \mathrm{~cm}^{3}\left(433 \mathrm{in}^{3}\right)$. The total nominal freeboard volume is about 14,890 $\mathrm{cm}^{3}\left(909 \mathrm{in}^{3}\right)$.

\subsection{GLASS PRODUCT TAPPING SYSTEM}

As the molten bath volume increases from added melted feed, the glass is drained semicontinuously depending on the glass production rate. The crucible includes a bottom drain assembly, which allows draining the crucible down to about a 10-cm (4-inch) depth, so that a sufficient height of molten glass remains in crucible to remain coupled with the induction field.

The tapped glass exits the tapper and gravity drains into a receiving pan. The CCIM holds only a small molten glass inventory in process at any given time, ranging to as much as $17,000 \mathrm{~cm}^{3}\left(1,040 \mathrm{in}^{3}\right)$. The receiving pan is sized to contain the full volume of glass in the melter if necessary, to avoid spilling molten glass onto the laboratory floor in an event where the full glass volume of the melter is drained at one time. 


\subsection{COOLING WATER SYSTEM}

Several of the power supply and melter components are water cooled:

- The radiofrequency (RF) generator

- The induction coil

- The melter crucible

The generator cooling water system, shown in Figure 3-4, consists of three separate loops. The primary loop circulates de-ionized, non-electrically-conductive cooling water through the cooled components of the power generator and the induction coil. A secondary cooling loop circulates city water and exchanges heat between two heat exchangers, one for the primary cooling loop and one for the external cooling loop. The external cooling loop for the power generator uses a water and propylene glycol mixture and is cooled in an outdoor water chiller.

The generator operation is interlocked with the cooling water outlet temperature, and is automatically de-energized if the generator cooling water outlet temperature exceeds a safe preset temperature and flowrate.

Figure 3-5 shows the cooling system for the melter crucible. The crucible has five separately cooled segments. Each of the five segments has separate flowrate control and monitoring, and outlet temperature monitoring. This closed loop exchanges heat from the crucible walls and bottom to a secondary loop that is cooled using an air cooled heat exchanger.

A gravity-fed emergency water system provides cooling water through the crucible in the event of a power outage. This ensures that, even if the crucible cooling water system fails, and the power to the melter is stopped, crucible cooling continues for a long enough time for the crucible to cool to a safe temperature $\left(<100^{\circ} \mathrm{C}\right)$ at which the water can be shut off.

\subsection{OFF-GAS TREATMENT SYSTEM}

The INL CCIM off-gas treatment system is shown in Figure 3-6. The system includes these components:

- Heated duct to the thermal reaction chamber (TRC)

- Thermal reaction chamber

- Off-gas quench section

- Wet scrubber system

- Induced draft fan 


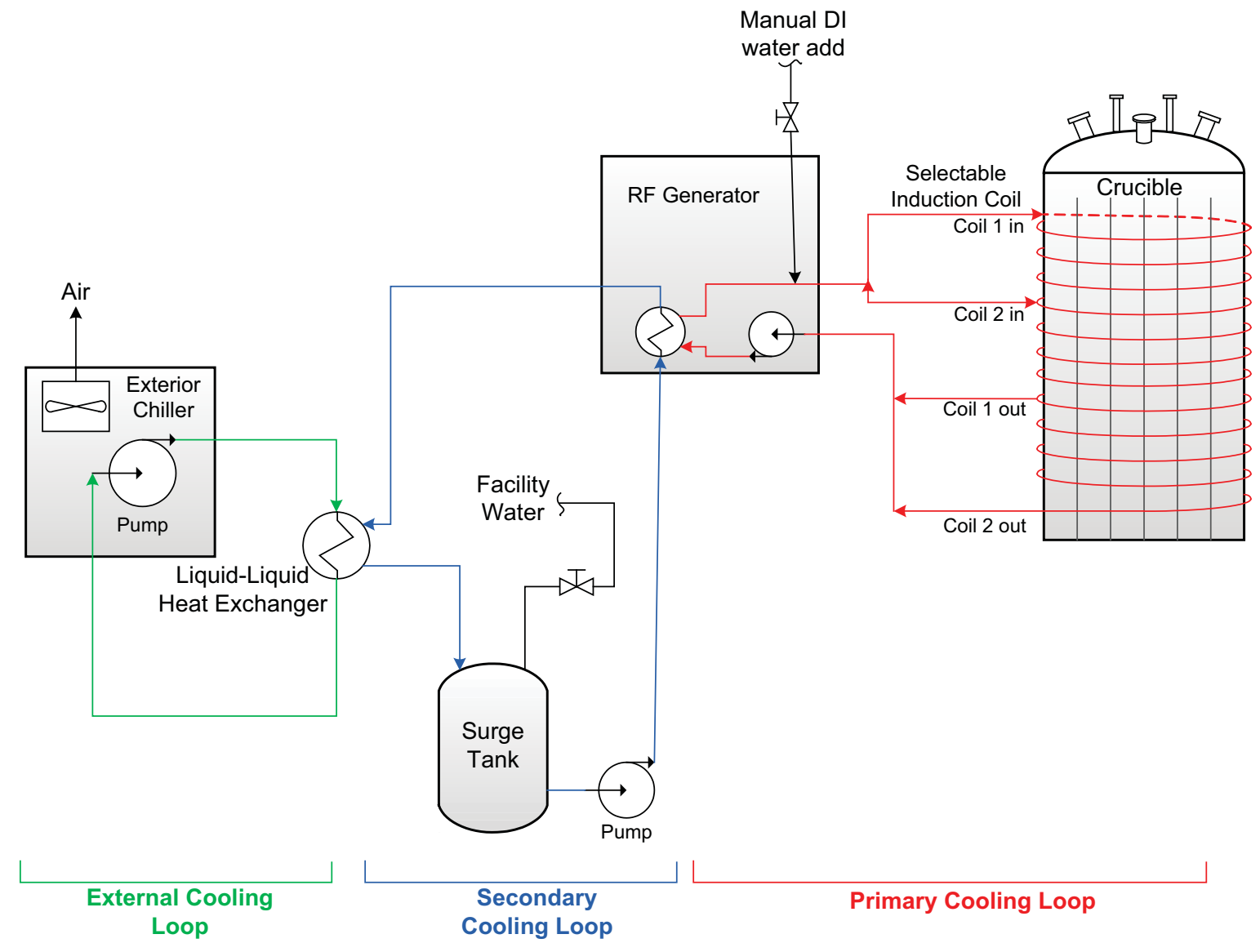

CCIM figures.vsd

Figure 3-4. INL CCIM generator cooling water system schematic.

\subsubsection{Heated Duct to the TRC}

A prototype heated inconel duct enables flow of off-gas from the melter to the TRC. This $79 \mathrm{~cm}(31$ in) long, $7 \mathrm{~cm}$ ( $2.8 \mathrm{inch})$ inside diameter duct is angled at 45 degrees from horizontal, and heated using a high-temperature electric resistance heating element to heat the duct wall up to $800^{\circ} \mathrm{C}$ if desired. The inside volume of this duct is about $2,910 \mathrm{~cm}^{3}\left(177 \mathrm{in}^{3}\right)$, about $16 \%$ of the total freeboard volume of the melter, lid, and duct.

This duct is designed to minimize gas condensation and particulate deposition, and, if heated hot enough, will encourage particulate deposits, if they form over time during operation, to melt and drain back into the melter. An observation/cleanout port is located in the wall of the TRC opposite the end of this duct, to enable monitoring and cleanout of this duct, if necessary, during operation. 


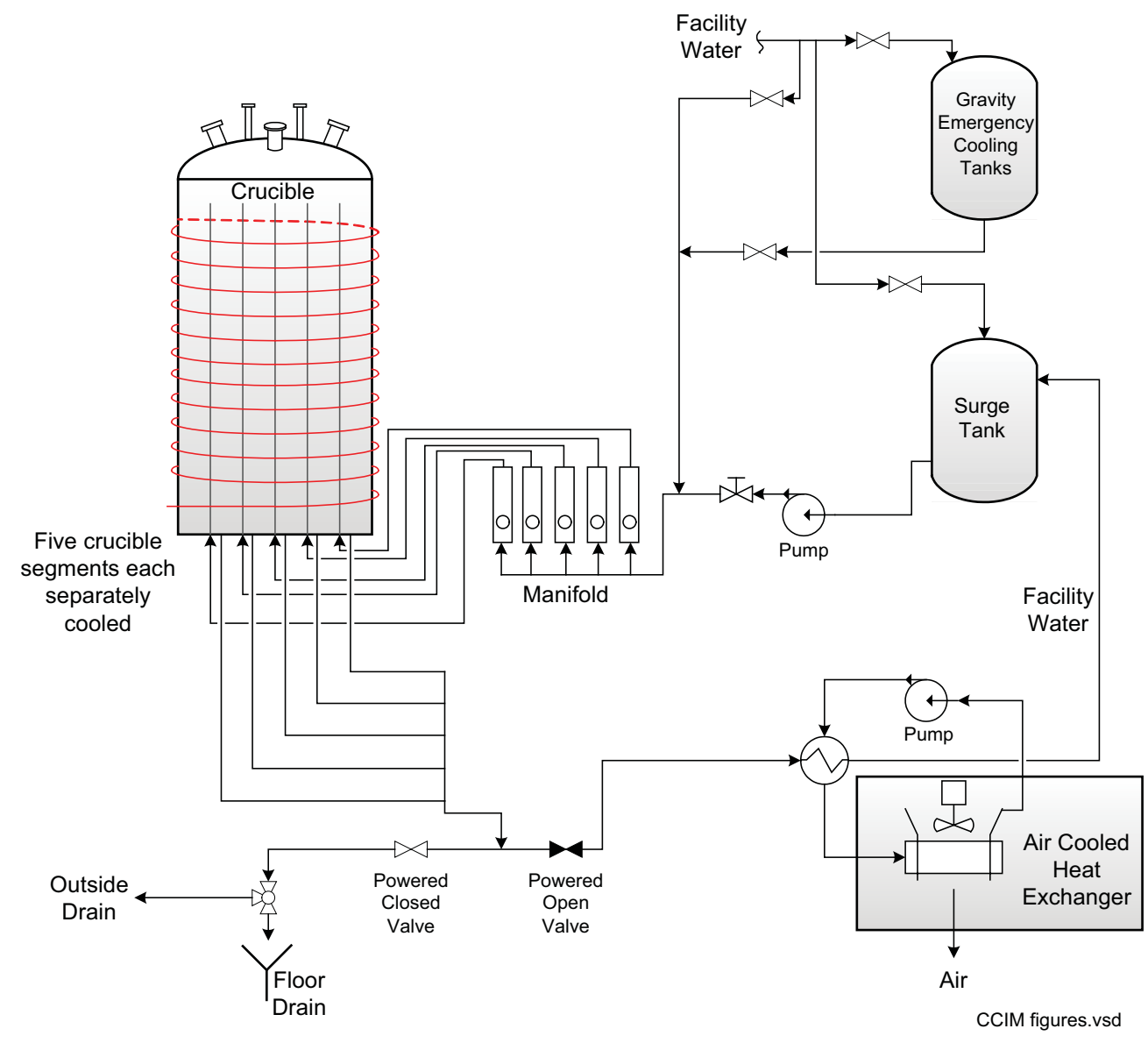

Figure 3-5. INL CCIM crucible cooling water system schematic.

This duct can be operated with the heater off, if desired, to avoid heating the off-gas and better emulate the process gas time-temperature history of larger CCIM systems. During this test, this heater was operated at a temperature setpoint of $200^{\circ} \mathrm{C}$ to ensure that moisture condensation would not occur in this section, and to also avoid excessively heating or cooling the melter off-gas, which tended to range between about $100-300^{\circ} \mathrm{C}$, depending on the melter feedrate and cold cap coverage on the molten glass. The Off-gas Test 1, when the fuse for the heater failed and the heater was turned off for the rest of the test.

The sample port for collecting process off-gas samples downstream of the melter is located near the outlet of this heated duct, 10 duct diameters downstream of the melter outlet and 1 diameter upstream of the inlet to the TRC, which is a suitable location for isokinetic particulate sampling in small ducts according to US Environmental Protection Agency (EPA) Method 1A ("Sample and Velocity Traverses for Stationary Sources with Small Stacks or Ducts," 40 CFR 60, Appendix A).

Two sample points are available for continuous emissions monitoring system (CEMS) measurements. One location is in the melter freeboard, through a sample tube that extends through the melter freeboard to a location at the inlet to the melter outlet duct. The sample port at the outlet of the heated duct can also be used for CEMS sampling, when manual sampling is not being performed in that port. 


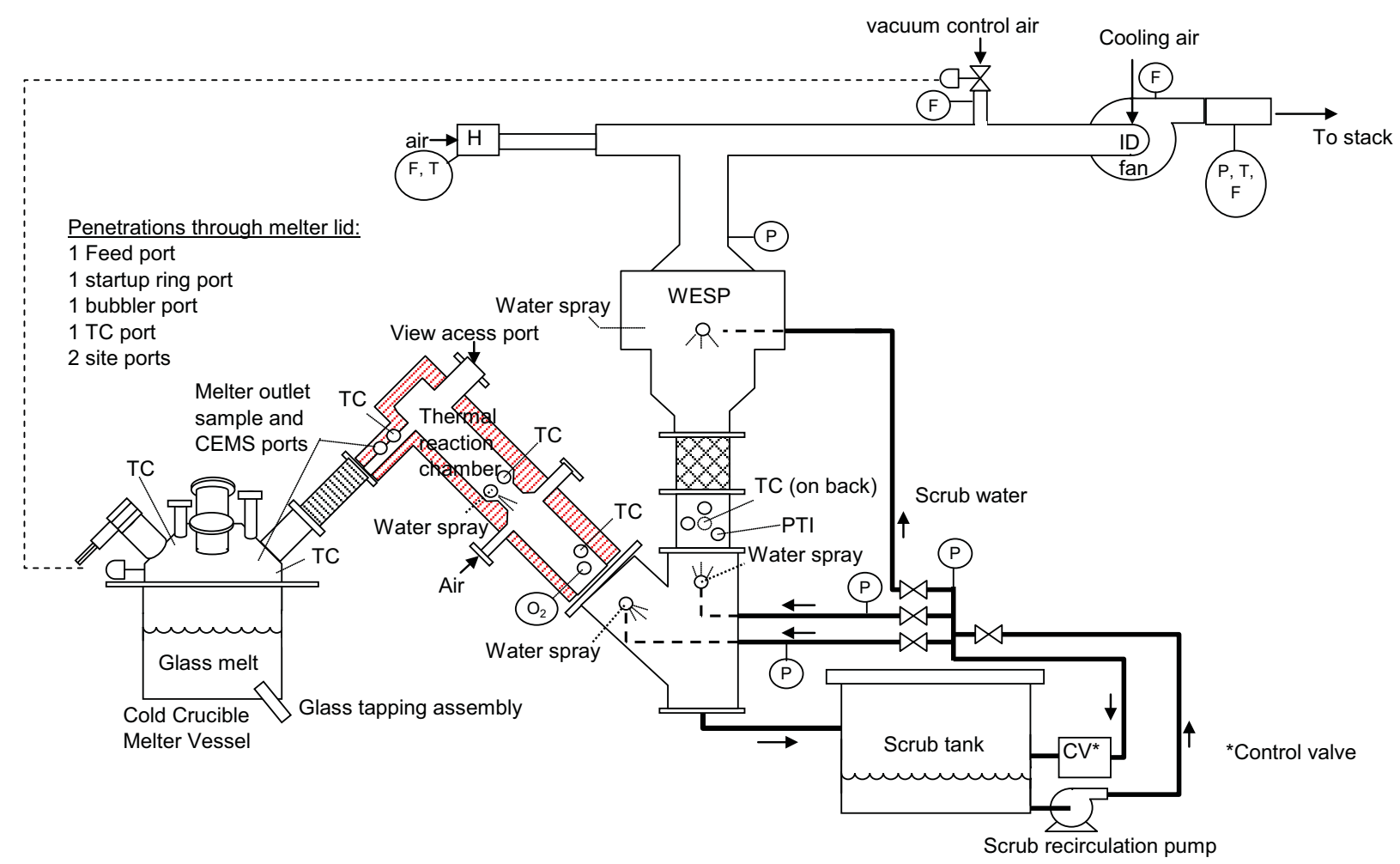

[ccim offgas system design calculations 29jan09.xls]process diagram 4

Figure 3-6. INL CCIM off-gas treatment system.

\subsubsection{Thermal Reaction Chamber}

The TRC is designed to perform nonselective, noncatalytic, thermal $\mathrm{NO}_{\mathrm{x}}$ reduction and also fully oxidize any reduced gas species such as $\mathrm{H}_{2}, \mathrm{CO}$, or $\mathrm{CH}_{4}$. The off-gas can be heated in the first stage using electrical heating to $\mathrm{NO}_{\mathrm{x}}$ reduction reaction temperatures (of around $800-1,000^{\circ} \mathrm{C}$ ) using an electric immersion heater. The immersion heater has a maximum temperature rating of $1,200^{\circ} \mathrm{C}$. The reaction chamber is sized and configured to provide adequate heat transfer surface area, mixing, and residence time to heat and maintain the gas at the design temperature for at least 2-seconds residence time. $\mathrm{NO}_{\mathrm{x}}$ destruction was not an objective of this test, and so this chamber, while heated to a nominal temperature of up to $500^{\circ} \mathrm{C}$, was not operated for $\mathrm{NO}_{\mathrm{x}}$ destruction.

The second stage of the TRC provides the capability of evaporative cooling of a water spray into the off-gas to cool the $\mathrm{NO}_{\mathrm{x}}$-reduced off-gas to about $800^{\circ} \mathrm{C}$, if the TRC is operated in the $\mathrm{NO}_{\mathrm{x}}$-reduction mode. This was not needed and not used in the OGSE test.

In the oxidizer section, air is normally added to provide oxygen for complete oxidation of $\mathrm{CO}$ and other products of incomplete combustion (PICs) that were formed or remain in the reducing section off-gas. The oxidizer section is designed consistent with typical efficient thermal oxidizer designs, with a residence time of at least 2 seconds. The temperature is controlled to avoid exceeding about $1,000^{\circ} \mathrm{C}$ by the water spray in stage two, to avoid excessive thermal $\mathrm{NO}_{\mathrm{x}}$ formation that could occur if temperatures significantly exceeded $1,000^{\circ} \mathrm{C}$. The TRC was not used in this test. 


\subsubsection{Off-gas Quench Section}

Following thermal oxidation the off-gas is cooled (quenched) by water spray evaporation to the adiabatic dewpoint of the off-gas with the added evaporated water. This section is constructed of Hastelloy steel to tolerate the initially high off-gas temperature and to provide good resistance to corrosion at both high and low temperatures.

\subsubsection{Wet Scrubber System}

Immediately following the temperature quench stage, the off-gas passes through a wet scrubber designed to remove acid gases and some of the residual particulate matter. The scrubber system includes the high performance scrubber itself, the scrub tank that collects and holds scrub solution, and the scrub solution recirculation system. The recirculation system includes a pump, valves, and piping to recirculate scrub solution to the spray quench nozzles in the off-gas quench section, and to the scrubber.

The scrubber is a wet electrostatic precipitator (WESP). The WESP uses electrical energy to charge entrained particulate matter and condensed water droplets, causing them to migrate to the collector walls. The WESP is self-cleaning. The electrodes are electrically isolated from the collectors, and purged with a dry air flowrate to prevent moisture condensation at this location. The water quench and scrubber recycle system was operated, to ensure that the melter off-gas was cooled before passing downstream of the scrubber.

\subsubsection{Induced Draft Fan}

The induced draft (ID) fan provides the motive force to draw the off-gas from the melter through the off-gas system. Since off-gas flowrates may vary widely under different operating conditions, a vacuum control system is used upstream of the variable-speed ID fan. This system includes a dilution air flowrate control damper that allows ambient air flow into the off-gas stream just upstream of the blower. This provides a faster response to melter vacuum changes than does changing the speed of the blower, once the blower speed is set for a total flowrate that provides the desired melter vacuum and ambient dilution air flowrates within controllable ranges. The dilution air damper position is automatically controlled based on the continuously-measured melter vacuum and the melter vacuum setpoint.

\subsection{PROCESS MONITORING AND CONTROL SYSTEM}

The CCIM test system is continuously monitored and controlled using a computer-based data acquisition and control system (DACS). The system includes a control computer, LabVIEW software, process and instrumentation diagram (P\&ID) displays, the Instrument Interface, plant instruments, the Control Interface, plant controls, and a video monitoring system. Key parameters for all subsystems are continuously monitored and controlled. Parameters that are continuously measured and recorded include temperatures, pressures, voltages, power levels, flowrates, and off-gas composition.

The CEMS is a component of the process monitoring and control system. The CEMS continuously samples and analyses the off-gas. The CEMS sampled melter off-gas from the freeboard of the melter during this test. The sample tube for the melter freeboard location penetrated through the freeboard to a location near the inlet of the melter off-gas pipe.

The CEMS includes a heated sample probe, heated sample line, heated filter, gas chiller, sample pump, gas distribution system to the analyzers, the analyzers, a calibration gas system, and data linking so the CEMS data are continuously, automatically, electronically logged.

All CEMS data were determined on a dry basis, after condensation of moisture from the sample gas. 
All components downstream of the sample gas chiller system are unheated because condensable moisture is removed in the chiller. The sample pump induces the negative pressure needed to draw the sample gas from the off-gas pipe into the CEMS. A backup filter located immediately downstream of the sample pump provides added protection for the flow meters and analyzers from particulate matter damage or fouling.

Total hydrocarbon (THC) analysis is made by flame ionization detection of carbon ions that are produced when hydrocarbon compounds are ionized at high temperatures in a hydrogen-air flame. The Method 25A procedure was modified to allow for chilling and condensation of the sample gas upstream of the THC analyzer. Condensate sampling performed in prior test programs that have used this modification to the THC analysis procedure have indicated negligible amounts of condensed hydrocarbons occur in most cases.

The components of the sample pump, and all other components of the CEMS that contact the sample gas, are constructed of stainless steel, Teflon, glass, or other materials designed to avoid reaction with the sample gas.

The CEMS analyzers were calibrated daily with calibration gases. 


\section{HANFORD LAW SIMULANT AND MELTER FEED}

The test was conducted to demonstrate the vitrification of the Hanford AZ-102 low activity waste (LAW) that contains relatively large amounts of sulfate and sodium, compared to other radioactive Hanford waste streams. The high sulfate content limits the potential loading of this waste stream in conventional borosilicate glass. This test demonstrated how this waste stream could be vitrified in an iron-phosphate glass that can tolerate higher levels of sulfate. The composition of the AZ-102 waste stream is shown in Table 4-1. This composition is normalized to a nominal $7 \mathrm{M} \mathrm{Na}$ content, although more dilute mixtures, as dilute as $1.3 \mathrm{M} \mathrm{Na}$, were also considered. The higher concentration mixture was selected for testing because of (a) the perceived flexibility in the ability of the Hanford Waste Treatment Process to concentrate waste streams prior to vitrification (which, by itself, increases the melter throughput), and (b) the expectation that less water dilution was acceptable from a melter feed system perspective.

Non-radioactive Cs, Re, and I were spiked into the simulant so that sample analysis and mass balances can be used to determine the fate of these elements.

\subsection{Glass Formulation Testing}

Testing to determine a suitable composition of iron-phosphate glass was performed by MS\&T and MO-SCI Corporation (Day 2011). This testing was a part of a broader effort to "determine the feasibility of melting an iron phosphate composition in a research size Joule heated melter (JHM) at PNNL and a cold crucible induction melter (CCIM) at INL for the purposes of vitrifying a high sulfate $(\sim 18$ $\mathrm{wt} \%) /$ high alkali $(\sim 80 \mathrm{wt} \%)$ containing Hanford AZ102 LAW and evaluating the properties of the iron phosphate waste forms so produced."

A matrix of 24 laboratory scale glass melts resulted in the determination of a baseline glass composition, called MS26AZ102F-2, which contained a waste loading of $26 \mathrm{wt} \%$ waste oxides, that had the desired properties. This glass can tolerate $4-8 \mathrm{x}$ higher levels of $\mathrm{SO}_{3}$ than can borosilicate glasses, which enables a waste loading that is $4-8 \mathrm{x}$ higher than can be achieved in borosilicate glasses, for Slimited waste streams such as the Hanford AZ-102 LAW waste. The glass can be melted at temperatures between $1,030-1,050^{\circ} \mathrm{C}$, a very reasonable temperature range for both joule-heated and cold crucible induction melters. This moderate temperature range shows promise for retention of semivolatile radionuclides such as $\mathrm{Cs}$ and $\mathrm{Tc}$. In their tests, the retention of nonradioactive $\mathrm{Cs}$ and $\mathrm{Re}(\mathrm{a}$ nonradioactive surrogate for Tc-99) was relatively high, ranging from $92-100 \%$ for $\mathrm{Cs}_{2} \mathrm{O}$, and $33-70 \%$ for $\mathrm{Re}_{2} \mathrm{O}_{7}$.

The glass durability was evaluated using the Product Consistency Test (PCT) and Vapor Hydration Test (VHT). The PCT and VHT results met the DOE requirements for both as-cooled (glassy) and controlled centerline cooling (CCC)-treated MS26AZ102F-2 waste forms.

\subsection{AZ-102 Melter Feed}

The amounts and types of glass forming chemicals needed to produce the target iron phosphate glass composition determined by the glass formulation studies are shown in Table 4-2. 
Table 4-1. Hanford AZ-102 LAW simulant.

Target volume of simulant:

$2 \mathrm{~L}$

Expected simulant density: $1.320 \mathrm{~g} / \mathrm{ml}$

\begin{tabular}{|c|c|c|c|c|c|c|c|c|c|c|c|c|c|c|c|c|}
\hline \multirow{2}{*}{\begin{tabular}{|l}
$\begin{array}{l}\text { Envelope } \\
\text { Constituents }\end{array}$ \\
- \\
\end{tabular}} & \multirow{2}{*}{\begin{tabular}{|c|} 
Mole wt \\
- \\
\end{tabular}} & \multicolumn{2}{|c|}{$\begin{array}{c}1.3 \mathrm{M} \text { Na Simulant } \\
\text { target }\end{array}$} & \multicolumn{2}{|c|}{$7 \mathrm{M} \mathrm{Na}$ Simulant target } & \multicolumn{2}{|c|}{$\begin{array}{l}7 \mathrm{M} \mathrm{Na} \text { Simulant } \\
\text { calculated from } \\
\text { ingredients }\end{array}$} & \multirow{2}{*}{$\begin{array}{c}\text { Glass } \\
\text { Oxide } \\
- \\
\end{array}$} & \multirow[t]{2}{*}{ Mole wt } & \multicolumn{2}{|c|}{$\begin{array}{c}\text { TRR-PLT-073 } \\
\text { Target Glass Oxide }\end{array}$} & \multicolumn{2}{|c|}{$\begin{array}{c}\text { Glass Oxide calculated } \\
\text { from ingredients }\end{array}$} & \multirow{2}{*}{$\frac{\text { FeP glass }}{\mathrm{wt} \%}$} & \multirow{2}{*}{ 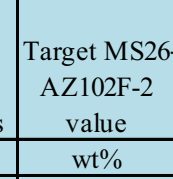 } & \multirow[t]{2}{*}{\begin{tabular}{|c} 
Calc'd value \\
$\%$ difference \\
from the \\
target value
\end{tabular}} \\
\hline & & $\mathrm{mg} / \mathrm{L}$ & M & $\mathrm{mg} / \mathrm{L}$ & M & $\mathrm{mg} / \mathrm{L}$ & M & & & $\mathrm{mg} / \mathrm{L}$ & $\mathrm{wt} \%$ & $\mathrm{mg} / \mathrm{L}$ & $\mathrm{wt} \%$ & & & \\
\hline $\mathrm{Al}$ & 26.98 & 75.8 & 0.003 & 408 & 0.016 & 408 & 0.015 & $\mathrm{Al}_{2} \mathrm{O}_{3}$ & 101.96 & 143 & 0.27 & 772 & 0.27 & 12.96 & 13.21 & $-1.9 \%$ \\
\hline $\mathrm{B}$ & 10.81 & 15.6 & 0.001 & 84 & 0.005 & 84 & 0.008 & $\mathrm{~B}_{2} \mathrm{O}_{3}$ & 69.62 & 50 & 0.10 & 272 & 0.10 & 0.025 & 0.030 & $-16.4 \%$ \\
\hline $\mathrm{Cr}$ & 52 & 288.8 & 0.006 & 1,555 & 0.032 & 1,556 & 0.030 & $\mathrm{Cr}_{2} \mathrm{O}_{3}$ & 151.99 & 422 & 0.81 & 2,274 & 0.81 & 2.71 & 2.70 & $0.5 \%$ \\
\hline Cs Spike \$ & 132.91 & 247 & 0.002 & 1,330 & 0.011 & 1,331 & 0.010 & $\mathrm{Cs}_{2} \mathrm{O}$ & 281.81 & 262 & 0.50 & 1,411 & 0.50 & 0.13 & 0.13 & $0.0 \%$ \\
\hline $\mathrm{K}$ & 39.1 & 1306.2 & 0.033 & 7,033 & 0.178 & 7,037 & 0.180 & $\mathrm{~K}_{2} \mathrm{O}$ & 94.2 & 1,573 & 3.01 & 8,477 & 3.01 & 0.78 & 0.78 & $0.2 \%$ \\
\hline $\mathrm{Na}$ & 22.99 & 29887 & 1.300 & 160,930 & 7.000 & 161,006 & 7.003 & $\mathrm{Na}_{2} \mathrm{O}$ & 61.98 & 40,287 & 76.96 & 217,032 & 76.96 & 20.01 & 20.03 & $-0.1 \%$ \\
\hline $\mathrm{Si}$ & 28.09 & 105.4 & 0.004 & 568 & 0.022 & 568 & 0.020 & $\mathrm{SiO}_{2}$ & 60.08 & 225 & 0.43 & 1,215 & 0.43 & 5.53 & 5.58 & $-0.9 \%$ \\
\hline $\mathrm{Cl}$ & 35.45 & 73.6 & 0.002 & 396 & 0.011 & 396 & 0.011 & $\mathrm{Cl}$ & 35.45 & 74 & 0.14 & 396 & 0.14 & 0.037 & 0.040 & $-8.6 \%$ \\
\hline $\mathrm{F}$ & 19 & 311.4 & 0.016 & 1,677 & 0.086 & 1,677 & 0.088 & $\mathrm{~F}$ & 19 & 311 & 0.59 & 1,677 & 0.59 & 0.15 & 0.16 & $-3.3 \%$ \\
\hline I spike & 126.9 & --- & --- & 282 & 0.00222 & 282 & 0.002 & I & 126.9 & 52 & 0.10 & 282 & 0.10 & 0.03 & & \\
\hline $\mathrm{PO} 4$ & 94.97 & 152.4 & 0.002 & 821 & 0.011 & 821 & 0.009 & $\mathrm{P}_{2} \mathrm{O}_{5}$ & 141.94 & 114 & 0.22 & 614 & 0.22 & 38.14 & 38.06 & $0.2 \%$ \\
\hline $\mathrm{SO} 4$ & 96.06 & 10535 & 0.110 & 56,727 & 0.592 & 56,744 & 0.591 & $\mathrm{SO}_{3}$ & 80.06 & 8,780 & 16.77 & 47,293 & 16.77 & 4.36 & 4.37 & $-0.2 \%$ \\
\hline Re Spike \$ & 186.21 & 40.3 & 0.0002 & 217 & 0.0011 & 217 & 0.0012 & $\mathrm{Re}_{2} \mathrm{O}_{7}$ & 484.41 & 52 & 0.10 & 282 & 0.10 & 0.026 & 0.030 & $-13.2 \%$ \\
\hline $\mathrm{NO} 2$ & 46.01 & 14572 & 0.317 & 78,465 & 1.707 & 78,503 & 1.706 & \begin{tabular}{|l|}
$\mathrm{Bi} 2 \mathrm{O} 3$ \\
\end{tabular} & & - & - & & & 1.76 & 1.77 & $-0.4 \%$ \\
\hline NO3 & 62 & 4820 & 0.078 & 25,954 & 0.420 & 25,965 & 0.419 & $\mathrm{CaO}$ & & - & - & & & 1.06 & 1.06 & $0.3 \%$ \\
\hline $\mathrm{CO} 3$ & 60.01 & 16471 & 0.274 & 88,690 & 1.475 & 88,739 & 1.479 & $\mathrm{Fe} 2 \mathrm{O} 3$ & & - & - & & & 7.29 & 7.10 & $2.6 \%$ \\
\hline Org. Carbon & 12.01 & 374.8 & 0.031 & 2,018 & 0.167 & - & - & $\mathrm{La} 2 \mathrm{O} 3$ & & - & - & & & 0.71 & 0.71 & $0.6 \%$ \\
\hline Oxalate & 88.02 & 1383 & 0.016 & 7,447 & 0.086 & 7,451 & 0.085 & $\mathrm{ZnO}$ & & - & - & & & 3.57 & 3.66 & $-2.5 \%$ \\
\hline- & & - & - & & & & & $\mathrm{ZrO} 2$ & & - & - & & & 0.71 & 0.71 & $0.6 \%$ \\
\hline- & & - & - & & & & & SUM & & 52,347 & 100.00 & 281,995 & 100.00 & 100.00 & & \\
\hline \multicolumn{17}{|c|}{$\begin{array}{l}\text { Notes: } \\
\text { 1. "-" Empty data field. }\end{array}$} \\
\hline
\end{tabular}

[CCIM Test Dec2010 Results 13Sept current .xlsx]AZ-102+I glass 
Table 4-2. Glass forming chemicals added to simulant.

\begin{tabular}{|c|c|c|c|c|c|c|c|c|c|c|c|c|c|}
\hline \multirow[t]{2}{*}{ AZ-102 simulant $\mathrm{Na}$ molarity } & \multicolumn{2}{|c|}{$7 \mathrm{M}$} & & & & \multicolumn{4}{|c|}{ Oxide basis } & \multicolumn{4}{|c|}{ Elemental basis } \\
\hline & Ingredient & mole wt & $\mathrm{g} / \mathrm{L}$ simulant & total kg & assay & oxide & mole wt & $\mathrm{gm} / \mathrm{L}$ & $\mathrm{wt} \%$ & element & mole wt & $\mathrm{g} / \mathrm{L}$ & $\mathrm{wt} \%$ \\
\hline Chromium oxide (ACROS 19208-500) & $\mathrm{Cr} 2 \mathrm{O} 3$ & 152 & 27.241 & 23.496 & 0.990 & $\mathrm{Cr} 2 \mathrm{O} 3$ & 152 & 26.969 & 3.38 & $\mathrm{Cr}$ & 52 & 18.452 & 2.32 \\
\hline Silica oxide & $\mathrm{SiO} 2$ & 60.09 & 58.348 & 50.326 & 1.000 & $\mathrm{SiO} 2$ & 60.09 & 58.348 & 7.32 & $\mathrm{Si}$ & 28.09 & 27.276 & 3.42 \\
\hline Bismuth hydroxide & $\mathrm{H} 3 \mathrm{BiO} 3$ & 260 & 21.394 & 18.453 & 0.990 & $\mathrm{Bi} 2 \mathrm{O} 3$ & 466 & 18.981 & 2.38 & $\mathrm{Bi}$ & 209 & 17.026 & 2.14 \\
\hline Calcium phosphate & $\mathrm{HCaPO} 4$ & 136.05 & 28.344 & 24.447 & 0.980 & $\mathrm{CaO}$ & 56.08 & 11.450 & 1.44 & $\mathrm{Ca}$ & 40.08 & 8.183 & 1.03 \\
\hline Iron oxide (Prince 5001) & $\mathrm{Fe} 2 \mathrm{O} 3$ & 159.7 & 79.275 & 68.376 & 0.990 & $\mathrm{Fe} 2 \mathrm{O} 3$ & 159.7 & 78.482 & 9.85 & $\mathrm{Fe}$ & 55.85 & 54.893 & 6.89 \\
\hline Lanthanum oxide & $\mathrm{La} 2 \mathrm{O} 3$ & 325.8 & 7.697 & 6.639 & 0.999 & $\mathrm{La} 2 \mathrm{O} 3$ & 325.8 & 7.689 & 0.96 & $\mathrm{La}$ & 138.9 & 6.556 & 0.82 \\
\hline Zinc oxide & $\mathrm{ZnO}$ & 81.39 & 38.526 & 33.229 & 0.998 & $\mathrm{ZnO}$ & 81.39 & 38.449 & 4.82 & $\mathrm{Zn}$ & 65.39 & 30.890 & 3.88 \\
\hline Zirconium oxide & $\mathrm{ZrO} 2$ & 123.22 & 7.690 & 6.633 & 1.000 & $\mathrm{ZrO} 2$ & 123.22 & 7.690 & 0.96 & $\mathrm{Zr}$ & 91.22 & 5.693 & 0.71 \\
\hline Aluminum hydroxide to replace AIPO4 & $\mathrm{Al}(\mathrm{OH}) 3$ & 77.98 & 67.722 & 58.412 & 0.995 & $\mathrm{~A} 2 \mathrm{O} 3$ & 101.96 & 138.785 & 17.41 & $\mathrm{Al}$ & 26.98 & 73.449 & 9.22 \\
\hline Aluminum metaphosphate & $\mathrm{Al}(\mathrm{PO} 3) 3$ & 263.89 & 503.457 & 434.242 & 0.974 & $\mathrm{P} 2 \mathrm{O} 5$ & 141.94 & 410.124 & 51.46 & $\mathrm{P} 2 \mathrm{O} 5$ & 141.94 & 410.124 & 51.46 \\
\hline Total simulant, $\mathrm{L}$ & \multicolumn{2}{|c|}{$862.5 \mathrm{~L}$} & & & & & SUM & 796.966 & 100.00 & & SUM & 652.543 & 81.878 \\
\hline \multicolumn{14}{|c|}{$\begin{array}{l}\text { Notes: } \\
\text { 1. GFC - glass forming chemicals } \\
\text { 2. The } \mathrm{g} / \mathrm{L} \text { simulant data for the ingredients is from Hansen, email communication on October } 17,2010 \text {. } \\
\text { 3. Sufficient AlPO4 was not available, so the AIPO4 in the initial } \mathrm{GFC} \text { recipe was replaced with } \mathrm{Al}(\mathrm{OH}) 3 \text { and additional } \mathrm{Al}(\mathrm{PO} 3) 3 \text {, adjusted to provide the } \mathrm{Al} \text { and the } \mathrm{P} \\
\text { that was initally provided by the AlPO4. }\end{array}$} \\
\hline
\end{tabular}

[CCIM Test Dec2010 Results 13Sept current .xlsx]GFCs without AlPO4 
Glass-forming chemicals were selected based on commercial availability, tests performed at SRNL to evaluate rheology and stability over time, and the ability to combine the different chemicals with the components of the AZ-102 waste simulant to produce a glass that matches the target MS26AZ102F-2 waste form composition. The selection was complicated because, following the initial determination, we found that the desired amount of aluminum phosphate $\left(\mathrm{AlPO}_{4}\right)$ was not commercially available. This forced a change from the aluminum phosphate to aluminum hydroxide and aluminum metaphosphate $\left[\mathrm{Al}\left(\mathrm{PO}_{3}\right)_{3}\right]$ to provide the needed aluminum and phosphate.

When the glass forming chemicals are added to the waste simulant, the mixture is labeled "melter feed" to differentiate this composition from the waste simulant composition. Table 4-3 shows the calculated and measured composition of the melter feed.

Some additional water was added during the pretest process operations. In addition, $25 \mathrm{~g}$ of sugar per liter of simulant was added. The added water and sugar changed the volume, density, and composition of the final melter feed, as shown in Table 4-4. This table shows the results of a melter feed sample analysis. This analysis showed that the concentrations of most of the analyzed analytes agreed with the target values within about $30 \%$. The measured concentrations of a few elements varied more than about $30 \%$ from the target values. The variances in the concentrations of $\mathrm{Cl}, \mathrm{F}$, and $\mathrm{Zr}$ may be due, at least in part, to the relatively low concentrations of these elements in the melter feed. Analytical errors can have a greater impact in the measured concentrations of these elements.

\subsection{Melter Startup Glass}

Melter startup glass was prepared and provided for the test so that the startup glass had a composition similar to the intended iron phosphate product glass. The composition of the startup glass is shown in Table 4-5. Cs and Re were also spiked into the starting glass added to the melter prior to the test, so that the Cs and Re concentrations in the starting glass were about the same as in the product glass from the melter feed. 
Table 4-3. Calculated melter feed composition.

\begin{tabular}{|c|c|c|c|c|c|c|c|}
\hline \multirow[b]{2}{*}{ Species } & \multirow[b]{2}{*}{ Mole wt } & \multicolumn{2}{|c|}{$\begin{array}{c}7 \mathrm{M} \text { Na Simulant } \\
\text { calculated from } \\
\text { ingredients }\end{array}$} & \multicolumn{2}{|c|}{ From GFCs } & \multicolumn{2}{|l|}{ Total } \\
\hline & & $\mathrm{g} / \mathrm{L}$ & $\mathrm{M}$ & $\mathrm{g} / \mathrm{L}$ & M & $\mathrm{g} / \mathrm{L}$ & $\mathrm{M}$ \\
\hline $\mathrm{Al}$ & 26.98 & 0.32 & 0.013 & 57.4 & 2.13 & 57.7 & 2.14 \\
\hline $\mathrm{B}$ & 10.81 & 0.066 & 0.004 & & & 0.066 & 0.0042 \\
\hline $\mathrm{Cr}$ & 52.00 & 1.21 & 0.025 & 14.4 & 0.28 & 15.6 & 0.30 \\
\hline Cs Spike \$ & 132.91 & 1.04 & 0.008 & & & 1.0 & 0.0084 \\
\hline $\mathrm{K}$ & 39.10 & 5.49 & 0.139 & & & 5.5 & 0.14 \\
\hline $\mathrm{Na}$ & 22.99 & 126 & 5.469 & & & 125.7 & 5.47 \\
\hline $\mathrm{Si}$ & 28.09 & 0.44 & 0.017 & 21.3 & 0.76 & 21.8 & 0.78 \\
\hline $\mathrm{Cl}$ & 35.45 & 0.31 & 0.008 & & & 0.31 & 0.0084 \\
\hline$F$ & 19.00 & 1.31 & 0.067 & & & 1.3 & 0.067 \\
\hline I spike & 126.90 & 0.22 & 0.002 & & & 0.22 & 0.0017 \\
\hline $\mathrm{PO} 4$ & 94.97 & 0.64 & 0.008 & & & 0.64 & 0.0084 \\
\hline $\mathrm{SO} 4$ & 96.06 & 44.3 & 0.463 & & & 44.3 & 0.46 \\
\hline Re Spike \$ & 186.21 & 0.17 & 0.001 & & & 0.17 & 0.00084 \\
\hline $\mathrm{NO} 2$ & 46.01 & 61.3 & 1.334 & & & 61.3 & 1.33 \\
\hline $\mathrm{NO} 3$ & 62.00 & 20.3 & 0.328 & & & 20.3 & 0.33 \\
\hline $\mathrm{CO} 3$ & 60.01 & 69.3 & 1.153 & & & 69.3 & 1.15 \\
\hline Org. Carbon & 12.01 & 1.58 & 0.130 & & & 1.6 & 0.13 \\
\hline Oxalate $(\mathrm{C} 2 \mathrm{O} 4)$ & 88.02 & 5.82 & 0.067 & & & 5.8 & 0.067 \\
\hline $\mathrm{Bi}$ & 209.00 & & & 13.3 & 0.06 & 13.3 & 0.064 \\
\hline $\mathrm{Ca}$ & 40.08 & & & 6.4 & 0.16 & 6.4 & 0.16 \\
\hline $\mathrm{Fe}$ & 55.85 & & & 42.9 & 0.77 & 42.9 & 0.77 \\
\hline $\mathrm{La}$ & 138.90 & & & 5.1 & 0.04 & 5.1 & 0.037 \\
\hline $\mathrm{Zn}$ & 65.39 & & & 24.1 & 0.37 & 24.1 & 0.37 \\
\hline $\mathrm{Zr}$ & 91.22 & & & 4.4 & 0.05 & 4.4 & 0.049 \\
\hline Al & 26.98 & & & 57.4 & 2.13 & 57.4 & 2.13 \\
\hline $\mathrm{P} 2 \mathrm{O} 5$ & 141.94 & & & 320.4 & 2.26 & 320.4 & 2.26 \\
\hline Totals & & 339.5 & & 567.2 & & 906.7 & \\
\hline \multicolumn{8}{|l|}{ Notes: } \\
\hline 1. Water: & \multicolumn{4}{|c|}{$847 \mathrm{~g} / \mathrm{L}$ simulant } & \multicolumn{3}{|c|}{$662 \mathrm{~g} / \mathrm{L}$ melter feed } \\
\hline \multicolumn{6}{|c|}{ 2. Volume increase from the addition of the GFCs: } & \multicolumn{2}{|l|}{$28.0 \%$} \\
\hline \multicolumn{6}{|c|}{ 3. Measured density, $\mathrm{g} / \mathrm{ml}$ : } & \multicolumn{2}{|c|}{$1.67 \mathrm{~g} / \mathrm{ml}$} \\
\hline \multicolumn{6}{|c|}{ 4. Glass from simulant, oxide bas is, gm/L simulant from Table 5-1: } & \multicolumn{2}{|c|}{$282 \mathrm{~g} / \mathrm{L}$} \\
\hline \multicolumn{6}{|c|}{ 5. Waste loading: } & \multicolumn{2}{|l|}{$26.0 \%$} \\
\hline \multicolumn{6}{|c|}{ 6. Total glass, gm/L of simulant: } & \multicolumn{2}{|c|}{$1,085 \mathrm{~g} / \mathrm{L}$} \\
\hline \multicolumn{6}{|c|}{ 7. Glass formers on an oxide basis, gm/L of simulant: } & \multicolumn{2}{|c|}{$803 \mathrm{~g} / \mathrm{L}$} \\
\hline \multicolumn{6}{|c|}{ 8. Total glass, oxide bas is, $\mathrm{gm} / \mathrm{L}$ of melter feed: } & \multirow{2}{*}{\multicolumn{2}{|c|}{$847 \mathrm{~g} / \mathrm{L}$}} \\
\hline 9. The concentr & are normalize & to the $\mathrm{v}$ & ne of the & elter fe & the & & \\
\hline
\end{tabular}

[CCIM Test Dec2010 Results 13Sept current .xlsx]melter feed 
Table 4-4. Final melter feed composition accounting for water dilution and sugar addition.

\begin{tabular}{|c|c|c|c|c|c|c|c|c|c|}
\hline \multirow[b]{2}{*}{ Species } & \multirow[b]{2}{*}{ Mole wt } & \multicolumn{2}{|c|}{$\begin{array}{c}7 \mathrm{M} \mathrm{Na} \text { Simulant } \\
\text { calculated from } \\
\text { ingredients }\end{array}$} & \multicolumn{2}{|c|}{ From GFCs } & \multicolumn{2}{|c|}{$\begin{array}{l}\text { Final undiluted } \\
\text { melter feed } \\
\text { composition }\end{array}$} & \multirow{2}{*}{$\begin{array}{c}\begin{array}{c}\text { Analysis of } \\
\text { melter } \\
\text { feed }\end{array} \\
\mathrm{g} / \mathrm{L}\end{array}$} & \multirow[t]{2}{*}{$\begin{array}{c}\text { Analytical value } \% \\
\text { diff from calc'd } \\
\text { value }\end{array}$} \\
\hline & & $\mathrm{g} / \mathrm{L}$ & $\mathrm{M}$ & $\mathrm{g} / \mathrm{L}$ & $\mathrm{M}$ & $\mathrm{g} / \mathrm{L}$ & $\mathrm{M}$ & & \\
\hline $\mathrm{Al}$ & 27.0 & 0.27 & 0.010 & 57.4 & 2.1 & 49.7 & 1.8 & 44.6 & $-11 \%$ \\
\hline B & 10.8 & 0.057 & 0.0052 & & & 0.049 & 0.0045 & 0.96 & -- \\
\hline $\mathrm{Cr}$ & 52.0 & 1.0 & 0.020 & 14.4 & 0.28 & 13.3 & 0.26 & 11.6 & $-15 \%$ \\
\hline Cs & 132.9 & 0.90 & 0.0067 & & & 0.77 & 0.0058 & -- & -- \\
\hline K & 39.1 & 4.7 & 0.12 & & & 4.1 & 0.10 & 6.0 & $32 \%$ \\
\hline $\mathrm{Na}$ & 23.0 & 108.4 & 4.7 & & & 93.4 & 4.1 & 124.5 & $25 \%$ \\
\hline $\mathrm{Si}$ & 28.1 & 0.38 & 0.014 & 21.3 & 0.76 & 18.7 & 0.67 & 18.0 & $-4 \%$ \\
\hline $\mathrm{Cl}$ & 35.5 & 0.27 & 0.0075 & & & 0.23 & 0.0065 & 0.16 & $-44 \%$ \\
\hline $\mathrm{F}$ & 19.0 & 1.1 & 0.059 & & & 0.97 & 0.051 & 0.16 & $-511 \%$ \\
\hline I & 126.9 & 0.19 & 0.0015 & & & 0.16 & 0.0013 & -- & -- \\
\hline PO4 & 95.0 & 0.55 & 0.0058 & & & 0.48 & 0.0050 & -- & -- \\
\hline $\mathrm{SO} 4$ & 96.1 & 38.2 & 0.40 & & & 32.9 & 0.34 & -- & -- \\
\hline $\mathrm{Re}$ & 186.2 & 0.15 & 0.00078 & & & 0.13 & 0.00068 & -- & -- \\
\hline $\mathrm{NO} 2$ & 46.0 & 52.8 & 1.1 & & & 45.6 & 0.99 & -- & -- \\
\hline NO3 & 62.0 & 17.5 & 0.28 & & & 15.1 & 0.24 & -- & -- \\
\hline $\mathrm{CO} 3$ & 60.0 & 59.7 & 1.00 & & & 51.5 & 0.86 & -- & -- \\
\hline Org. Carbon & 12.0 & 1.36 & 0.11 & & & 1.17 & 0.098 & -- & -- \\
\hline Oxalate (C2O4) & 88.0 & 5.02 & 0.06 & & & 4.32 & 0.049 & -- & -- \\
\hline $\mathrm{Bi}$ & 209.0 & & & 13.3 & 0.064 & 11.5 & 0.055 & 10.0 & $-15 \%$ \\
\hline $\mathrm{Ca}$ & 40.1 & & & 6.4 & 0.16 & 5.5 & 0.14 & 4.9 & $-12 \%$ \\
\hline $\mathrm{Fe}$ & 55.9 & & & 42.9 & 0.77 & 37.0 & 0.66 & 31.1 & $-19 \%$ \\
\hline $\mathrm{La}$ & 138.9 & & & 5.1 & 0.037 & 4.4 & 0.032 & 3.5 & $-26 \%$ \\
\hline $\mathrm{Zn}$ & 65.4 & & & 24.1 & 0.37 & 20.8 & 0.32 & 16.2 & $-29 \%$ \\
\hline $\mathrm{Zr}$ & 91.2 & & & 4.4 & 0.049 & 3.8 & 0.042 & 2.1 & $-82 \%$ \\
\hline $\mathrm{P} 2 \mathrm{O} 5$ & 141.9 & & & 320 & 2.3 & 276 & 1.9 & -- & -- \\
\hline Totals & -- & 293 & -- & 510 & -- & 692 & -- & 274 & - \\
\hline \multicolumn{6}{|c|}{$\mathrm{P}$ (normalized from total PO4 and P2O5) } & 121 & -- & 107 & $-13 \%$ \\
\hline S (normalized fros & SO4) & 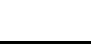 & & & & 11.0 & -- & 14.5 & $24 \%$ \\
\hline \multicolumn{10}{|l|}{ Notes: } \\
\hline \multicolumn{8}{|c|}{ 1. Water 4 gal added to 25 gal melter feed: } & \multicolumn{2}{|c|}{$15 \mathrm{~L}$ water } \\
\hline \multicolumn{6}{|c|}{ 2. Volume increase from added water: } & \multicolumn{4}{|c|}{1.16} \\
\hline \multicolumn{6}{|c|}{ 3. Total water content } & \multicolumn{2}{|c|}{$847 \mathrm{~g} / \mathrm{L}$ simulant } & \multicolumn{2}{|c|}{$730 \mathrm{~g} / \mathrm{L}$ melter feed } \\
\hline \multicolumn{6}{|c|}{ 3. Melter feed density, adjusted for water dilution, $\mathrm{g} / \mathrm{ml}$ : } & \multirow{2}{*}{\multicolumn{2}{|c|}{$1,846 \mathrm{~g}$ sugar }} & \multicolumn{2}{|c|}{$1.58 \mathrm{~g} / \mathrm{ml}$ melter feed } \\
\hline \multicolumn{6}{|c|}{ 4. Added sugar, $25 \mathrm{~g} / \mathrm{L}$ simulant: } & & & \multicolumn{2}{|c|}{$16.8 \mathrm{~g} / \mathrm{L}$ melter feed } \\
\hline \multicolumn{6}{|c|}{ 5. Total $\mathrm{C}$ content incl. $\mathrm{CO} 3$, oxalate, and sugar } & & & 18.6 & $\mathrm{~g} / \mathrm{L}$ melter feed \\
\hline 6. Revised densit & accountin & for wa & dilution & sugar & tion: & & & 1.59 & $\mathrm{~g} / \mathrm{ml}$ melter feed \\
\hline 7. Measured dilu & d, sugar-a & lded der & $\mathrm{y}$ (avera & f $3 \mathrm{me}$ & rements) & & & 1.58 & $\mathrm{~g} / \mathrm{ml}$ melter feed \\
\hline 8. Calculated gla & from dilut & d, suga & dded me & feed: & & & & 730 & $\mathrm{~g} / \mathrm{L}$ melter feed \\
\hline 9. Measured solul & e solids & & & & & & & $21.5 \%$ & \\
\hline 10. Measured ins & luble solids & & & & & & & $28.7 \%$ & \\
\hline
\end{tabular}


Table 4-5. Starter glass composition.

\begin{tabular}{|c|c|c|c|c|c|}
\hline \multirow[b]{3}{*}{ Oxide } & \multirow[b]{2}{*}{\begin{tabular}{|c|} 
Glass calc'd from \\
ingredients
\end{tabular}} & \multicolumn{3}{|c|}{ Analysis of starter glass } & \multirow[b]{2}{*}{$\begin{array}{l}\text { Analysis \% diff } \\
\text { from calc'd value }\end{array}$} \\
\hline & & $\begin{array}{c}\text { SRNL sample } \\
1031 \text { AVG- } \\
\text { starter glass }\end{array}$ & $\begin{array}{c}\text { MO-SCI } \\
\text { starter glass } \\
\text { sample }\end{array}$ & $\begin{array}{c}\text { Average } \\
\text { starterglass } \\
\text { sample results }\end{array}$ & \\
\hline & $w t \%$ & $w t \%$ & $\mathrm{wt} \%$ & $\mathrm{wt} \%$ & $\%$ \\
\hline $\mathrm{A} 12 \mathrm{O} 3$ & 12.96 & 12.69 & 13.00 & 12.85 & $-0.9 \%$ \\
\hline $\mathrm{B} 2 \mathrm{O} 3$ & 0.025 & ND & -- & -- & -- \\
\hline $\mathrm{Cr} 2 \mathrm{O} 3$ & 2.71 & 2.49 & 2.47 & 2.48 & $-8.6 \%$ \\
\hline $\mathrm{Cs} 2 \mathrm{O}$ & 0.13 & 0.14 & -- & 0.14 & $7.6 \%$ \\
\hline $\mathrm{K} 2 \mathrm{O}$ & 0.78 & 0.84 & 1.05 & 0.94 & $20.6 \%$ \\
\hline $\mathrm{Na} 2 \mathrm{O}$ & 20.01 & 19.37 & 19.30 & 19.34 & $-3.4 \%$ \\
\hline $\mathrm{SiO} 2$ & 5.53 & 5.96 & 6.07 & 6.02 & $8.8 \%$ \\
\hline $\mathrm{Cl}$ & 0.037 & -- & -- & -- & -- \\
\hline $\mathrm{F}$ & 0.15 & -- & -- & -- & -- \\
\hline I & 0.026 & ND & -- & -- & -- \\
\hline $\mathrm{P} 2 \mathrm{O} 5$ & 38.14 & 38.13 & 38.55 & 38.34 & $0.5 \%$ \\
\hline $\mathrm{SO} 3$ & 4.36 & 3.53 & 2.85 & 3.19 & $-26.8 \%$ \\
\hline $\mathrm{Re} 2 \mathrm{O} 7$ & 0.026 & 0.020 & -- & -- & $-23.2 \%$ \\
\hline Bi2O3 & 1.76 & 1.78 & 1.74 & 1.76 & $-0.1 \%$ \\
\hline $\mathrm{CaO}$ & 1.06 & 1.11 & 1.18 & 1.15 & $7.7 \%$ \\
\hline $\mathrm{Fe} 2 \mathrm{O} 3$ & 7.29 & 7.41 & 7.29 & 7.35 & $0.9 \%$ \\
\hline $\mathrm{La} 2 \mathrm{O} 3$ & 0.71 & 0.69 & 0.63 & 0.66 & $-7.8 \%$ \\
\hline $\mathrm{ZnO}$ & 3.57 & 3.58 & 3.57 & 3.57 & $0.1 \%$ \\
\hline $\mathrm{ZrO} 2$ & 0.71 & 0.75 & 0.61 & 0.68 & $-5.0 \%$ \\
\hline SUM & 100.00 & 98.49 & 98.29 & 98.45 & - \\
\hline
\end{tabular}

Notes:

1. The calculated values are determined from the masses of the simulant and glass former ingredients used to make the simulant and glass formers.

2. The analytical data is from the "SRNL glass results" tab in this file.

3. The measured values match fairly closely with the target values from MS26AZ102F-2, $\mathrm{B} 2 \mathrm{O} 3$ and $\mathrm{I}$, which are at the detection limit, SO3, which is about $19 \%$ less than the target value, perhaps due to some volatilization; and $\mathrm{Re} 2 \mathrm{O}$, which is about $23 \%$ less than the target value, perhaps due to some volatilization or rounding/analytical error at the low concentration. Otherwise, the starter glass analytical values are within about $15 \%$ of the target values.

[CCIM Test Dec2010 Results 13Sept current .xlsx]starter glass composition 


\section{TEST RESULTS}

Test runs were performed to accomplish the test objectives described in the test plan (Soelberg 2010). Process conditions were automatically and manually controlled to maintain stable conditions at each run condition. The test system was operated at selected operating conditions, while data were continuously, electronically logged, and also manually recorded onto data sheets. Samples from process input and output streams were collected for analysis. Three different test runs were performed:

- An initial parametric evaluation of operating conditions was performed on November 2010 to enable the operators to determine how to operate each subsystem within target ranges, and in some cases determine what those ranges are. Results of this parametric test are not included in this report.

- Following the initial parametric evaluation, a selected number of operating conditions was defined for longer-term operation, process measurements, and process sampling to meet test objectives in the test plan. Testing was started on December 6, 2010. By December 11, after several days of operation, it was found that the melter feed did not contain all of the calculated amount of aluminum metaphosphate needed to produce glass with the target iron phosphate glass composition. At this time, it was determined to shut down the melter system, remove the offspecification glass contents from the crucible, add the correct amount of aluminum phosphate to the melter feed, and restart the test. The duration of testing from December 6 to December 11 is not included in this test report.

- Following adjustment of the melter feed composition by adding an amount of iron phosphate proportional to the amount of remaining feed, and after cleaning out the crucible, melter freeboard, and off-gas duct, the iron phosphate test was restarted on December 13. Testing continued until December 16. The duration of testing between December 13-16 provides data for the target operating conditions and is reported in this report.

The test included sample collection for analysis of all input and output streams, so that laboratory

analyses and mass balances could be used to determine the fate of feed constituents, especially Cs and Re, spiked as surrogates for radioactive Cs and for noble metals in the actual Hanford LAW waste stream. Process streams that were sampled for analysis were:

- $\quad$ Melter feed

- $\quad$ Product glass

- Off-gas and particulate matter entrained in the off-gas

The off-gas was continuously monitored using a CEMS for $\mathrm{O}_{2}, \mathrm{CO}_{2}, \mathrm{H}_{2}, \mathrm{CO}, \mathrm{CH}_{4}, \mathrm{THC}$, and $\mathrm{NO}_{\mathrm{x}}$. The off-gas samples included EPA Method 29 for metals including Cs) and total particulate matter emissions, and EPA Method TO-14 for redundant $\mathrm{H}_{2}$ and $\mathrm{CH}_{4}$ measurement, and measuring speciated volatile organic compound (VOC) emissions. EPA Method 29 was performed isokinetically, and also measured off-gas velocity, flowrate, and $\mathrm{H}_{2} \mathrm{O}$ concentration.

\subsection{CCIM Test System Startup}

The test system startup included the following components:

- Complete pre-start procedure (make ready and power-on all subsystems per the startup sequence).

- Ensure that the feed tank is well stirred and circulated to suspend frit and UDS.

- Add start up glass and starting media to the crucible. 
- Start all subsystems in the proper sequence (cooling systems, induction power generator, TRC, wet scrubber, and ID fan) according to startup procedures.

- As the startup glass heats in the crucible, make adjustments to tune the induction power as needed for heatup. Monitor all other system parameters, especially the cooling systems.

- When the glass in the crucible is molten and has reached the target melt temperature, and other subsystems (cooling systems, TRC, wet scrubber, and ID fan) are operating within their startup parameters, then the melter is ready to start melter feed.

- Start melter feed following the feed startup checklist, which includes verification/ adjustment of all system operating conditions prior to starting melter feed.

- Adjust melter power levels, cooling system flowrates, and off-gas system parameters to reach and stabilize operation at the target operating conditions.

\subsection{Test System Operation}

The CCIM test system was operated to accomplish the pre-defined test objectives. Process conditions were either automatically or manually controlled to maintain stable conditions at each test condition. Operating data are continuously, electronically logged, and also manually recorded onto data sheets. The scope also included collection and analysis of samples from process input and output streams for selected test conditions, and post-test cleanout, inspection, and sampling.

When the melt level was high enough to start glass pouring, at any time during this test, glass pouring was initiated. Glass pouring was periodic, not continuous, starting and stopping to maintain the melt height within acceptable limits in the melter.

\subsection{Iron Phosphate Test Summary}

Figure 5-1 shows a summary of the iron phosphate test temperatures and power levels. The system was operated continuously over a time period of about 70 hours between December 13-16, 2010. Starting glass, manually added to the crucible prior to the test, became essentially completely molten and reached the target operating temperature of about $1,030^{\circ} \mathrm{C}$ in about 5 hours after induction power startup. The induction power system was operated at a frequency of $1.48 \mathrm{MHz}$, which was close to but higher than the target of about $0.9 \mathrm{MHz}$ that was calculated based on the molten iron-phosphate glass properties measured during the glass formulation tests. If a near-exact frequency match is not practical, then the next best alternative is for the operating frequency to be higher than the target frequency, where the energy deposition curve is relatively flat (the energy deposition curve drops off steeply at frequencies less than the target frequency).

As shown in Figure 5-2, simulant feed was started at 7.5 hours, and continued for a total of about 60 hours except for occasional short periods when the melter feed was turned off for short time periods for various operational reasons. The melter feedrate was varied from $0.63-3.2 \mathrm{~kg} / \mathrm{hr}$. A single bubbler was used with an air flowrate of about 1-1.5 lpm to provide some agitation and mixing in the melt to improve the feedrate. This bubbler also provides oxygen from the air mixed into the melt, which could tend to oxidize multi-valent species, such as $\mathrm{Fe}^{+2}$, to more oxidized forms, such as $\mathrm{Fe}^{+3}$.

Two test conditions were performed:

3. Nominal $1,030^{\circ} \mathrm{C}$ melt temperature, feedrate of $0.86 \mathrm{~L} / \mathrm{hr}(1.4 \mathrm{~kg} / \mathrm{hr})$, and nearly complete cold cap coverage, with a glass production rate of $0.66 \mathrm{~kg} / \mathrm{hr}$.

4. Nominal $1,100^{\circ} \mathrm{C}$ melt temperature, melter feed slurry feedrate of $2.0 \mathrm{~L} / \mathrm{hr}(3.2 \mathrm{~kg} / \mathrm{hr})$, a more complete cold cap was accomplished because of the higher feed rate, and the glass production rate was $1.5 \mathrm{~kg} / \mathrm{hr}$. 


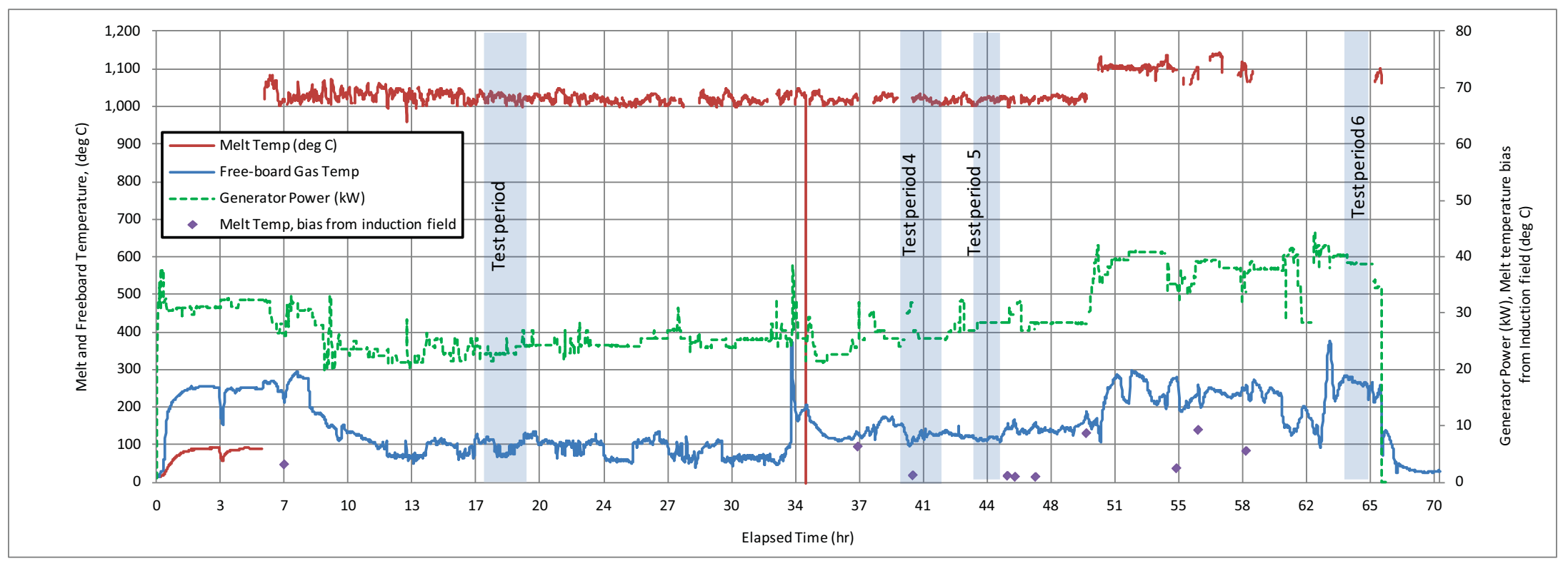

Figure 5-1. AZ-102 test temperature and power levels.

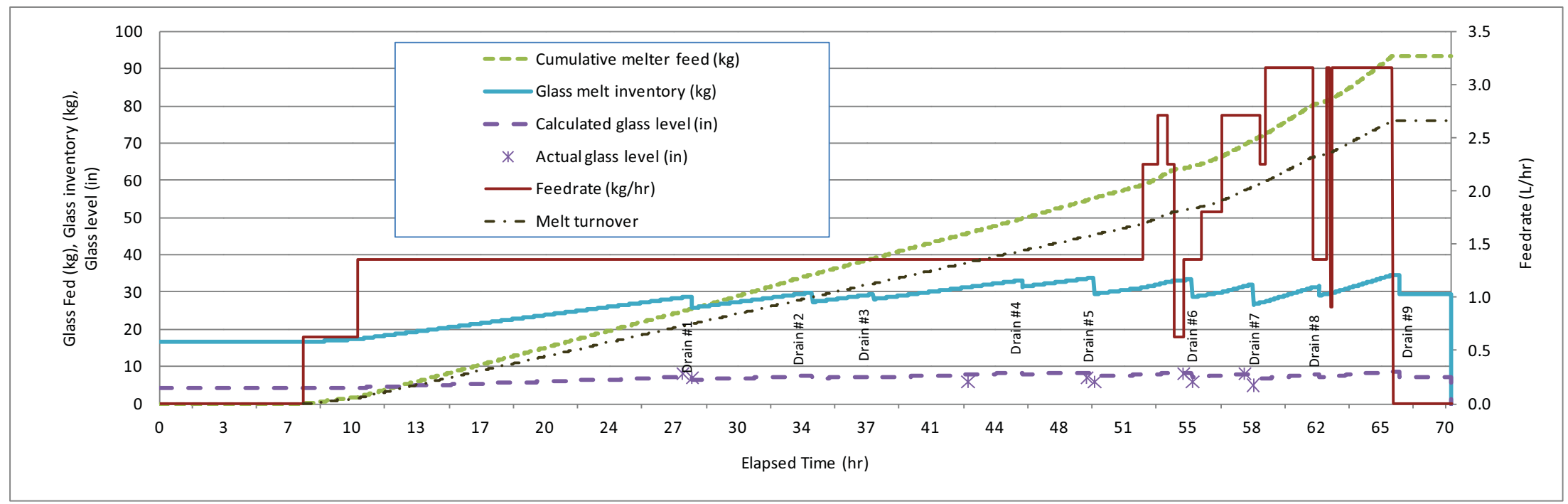

Figure 5-2. AZ-102 test feed and melter parameters. 
A total of $93 \mathrm{~kg}$ of feed was processed during the test, producing about $59 \mathrm{~kg}$ of weighed product glass. As the feed was fed to the melter, the glass level increased until a portion of the molten glass was drained from the melter. The glass drain could not be operated continuously because the glass drain rate was higher than the glass feedrate. Nine glass drains were performed during the test. Each mass of drained glass was weighed after cooling. Residual glass that did not drain out at the end of the test was manually removed from the melter and weighed after cooling.

The calculated glass inventory and melt height in the melter ranged between 17-35 kg and 4-9 inches, respectively. These values increased as feed was continuously fed, and decreased in step changes as glass was drained from the melter. The calculated melt height agreed well (within 1-2 inches) with the measured melt height. The duration of each drain was typically 5-10 minutes long, and is marked by a step-change decrease in the melt level. The frequency of melter drains increased as the melter feedrate was increased, so that the drains occurred about every 3-5 hours to maintain the desired melt inventory.

Test Condition 1 was maintained for about 50 operating hours. At that time, the operating conditions were changed to start the Test Condition 2. At the higher nominal melt temperature of about $1,100^{\circ} \mathrm{C}$, the melt rate increased, and the melter feedrate was more than doubled, from about $1.4 \mathrm{~kg} / \mathrm{hr}$ to about 3.2 $\mathrm{kg} / \mathrm{hr}$.

Off-gas sampling and continuous off-gas concentration monitoring were performed for each of these test conditions. Three sets of off-gas samples were collected for the first test condition and one sample was collected for the second test condition.

The average conditions measured for each off-gas sampling period are shown in Table 5-1. The reported melt temperatures have been corrected for a relatively small positive bias in the temperature measurement caused by the induction field, which averaged $4^{\circ} \mathrm{C}$ for this test. The measured, corrected melt temperatures typically ranged within $10^{\circ} \mathrm{C}$ of the target values.

Table 5-1. Average operating conditions for each test condition during the iron phosphate test.

\begin{tabular}{|c|c|c|c|c|c|c|c|c|c|c|c|c|c|c|}
\hline \multirow[b]{2}{*}{ Test } & \multirow[b]{2}{*}{$\begin{array}{l}\text { Test } \\
\text { Con- } \\
\text { dition }\end{array}$} & \multirow[b]{2}{*}{$\begin{array}{c}\text { Start } \\
\text { COT, } \\
\text { hrs }\end{array}$} & \multirow[b]{2}{*}{$\begin{array}{c}\text { End } \\
\text { COT, } \\
\text { hrs }\end{array}$} & \multirow[b]{2}{*}{$\begin{array}{c}\text { Duration, } \\
\text { hrs }\end{array}$} & \multicolumn{5}{|c|}{ Average operating conditions } & \multicolumn{3}{|c|}{ Average generator power } & \multirow[b]{2}{*}{$\begin{array}{c}\text { Specific } \\
\text { feed rate, } \\
\mathrm{kg} / \mathrm{m} 2 / \text { day } \\
\text { surface } \\
\text { area }\end{array}$} & \multirow[b]{2}{*}{$\begin{array}{c}\text { Specific } \\
\text { glass } \\
\text { produc- } \\
\text { tion rate, } \\
\mathrm{kg} / \mathrm{m} 2 / \text { day }\end{array}$} \\
\hline & & & & & $\begin{array}{c}\text { Melt T, } \\
{ }^{\circ} \mathrm{C}\end{array}$ & $\begin{array}{c}\text { Cold cap } \\
\text { coverage, } \\
\%\end{array}$ & $\begin{array}{l}\text { Free- } \\
\text { board } \\
\mathrm{T},{ }^{\circ} \mathrm{C}\end{array}$ & $\begin{array}{l}\text { Calc'd } \\
\text { melt } \\
\text { height, } \\
\mathrm{cm}\end{array}$ & $\begin{array}{l}\text { Feed } \\
\text { rate, } \\
\mathrm{kg} / \mathrm{hr}\end{array}$ & $\begin{array}{c}\text { Anode } \\
\text { current, } \\
\text { A }\end{array}$ & $\begin{array}{c}\text { Plate } \\
\text { voltage, } \\
\mathrm{kV}\end{array}$ & $\begin{array}{c}\text { Power, } \\
\text { kW }\end{array}$ & & \\
\hline 3 & 1 & 17.32 & 19.32 & 2.00 & 1,022 & $75 \%$ & 94 & 13.4 & 1.4 & 4.6 & 5.0 & 23.2 & 581 & 266 \\
\hline 4 & 1 & 39.60 & 41.60 & 2.00 & 1,020 & $75 \%$ & 126 & 18.2 & 1.4 & 4.5 & 4.7 & 26.5 & 581 & 266 \\
\hline 5 & 1 & 43.31 & 45.31 & 2.00 & 1,017 & $75 \%$ & 7119 & 19.7 & 1.4 & 5.2 & 5.4 & 28.0 & 581 & 266 \\
\hline 6 & 2 & 63.50 & 64.83 & 1.33 & 1,092 & $60 \%$ & 271 & 19.0 & 3.2 & 5.1 & 6.2 & 39.1 & 1,355 & 621 \\
\hline \multicolumn{15}{|c|}{$\begin{array}{l}\text { Notes: } \\
\text { 1. COT = Continuous operating time (elapsed time since test start). } \\
\text { 2. The sampling period includes the time during which the Method } 29 \text { metals and particulate sampling train is } \\
\text { collected, and the time prior to or after that represents the conditions for that test period. } \\
\text { 3. The melt temperature has been corrected for the average amount of bias to the TC reading caused by induction field. } \\
\text { 4. The melter cold top coverage is a subjective estimate made by looking through the site ports. } \\
\text { 5. The melter freeboard temperature TC is shielded from melt top radiation effects. }\end{array}$} \\
\hline
\end{tabular}

[CCIM Test Dec2010 Results 13Sept current .xlsx]test conditions

Some of the data in this table is shown graphically in Figure 5-3. At the higher melt temperature of Test Condition 2, the specific feedrate more than doubled. The input power rate increased by about $40 \%$. 


\subsection{Melter Feedrate}

The cold cap coverage was not complete, but was judged subjectively to be about right at typically $60-75 \%$ of total melt surface area coverage for the operating conditions. Figure 5-4 shows a view of the melt surface through a sight port in the melter lid, at a time with moderate cold cap coverage. The bright open molten melt area in the view is the area where the air bubbler (which is the left-most dark $1 / 4$-inch diameter tube in the view) agitates the surface and typically prevents complete closure of a cold cap on the melt surface. The right-hand $1 / 4$-inch tube in the view is the feed tube.

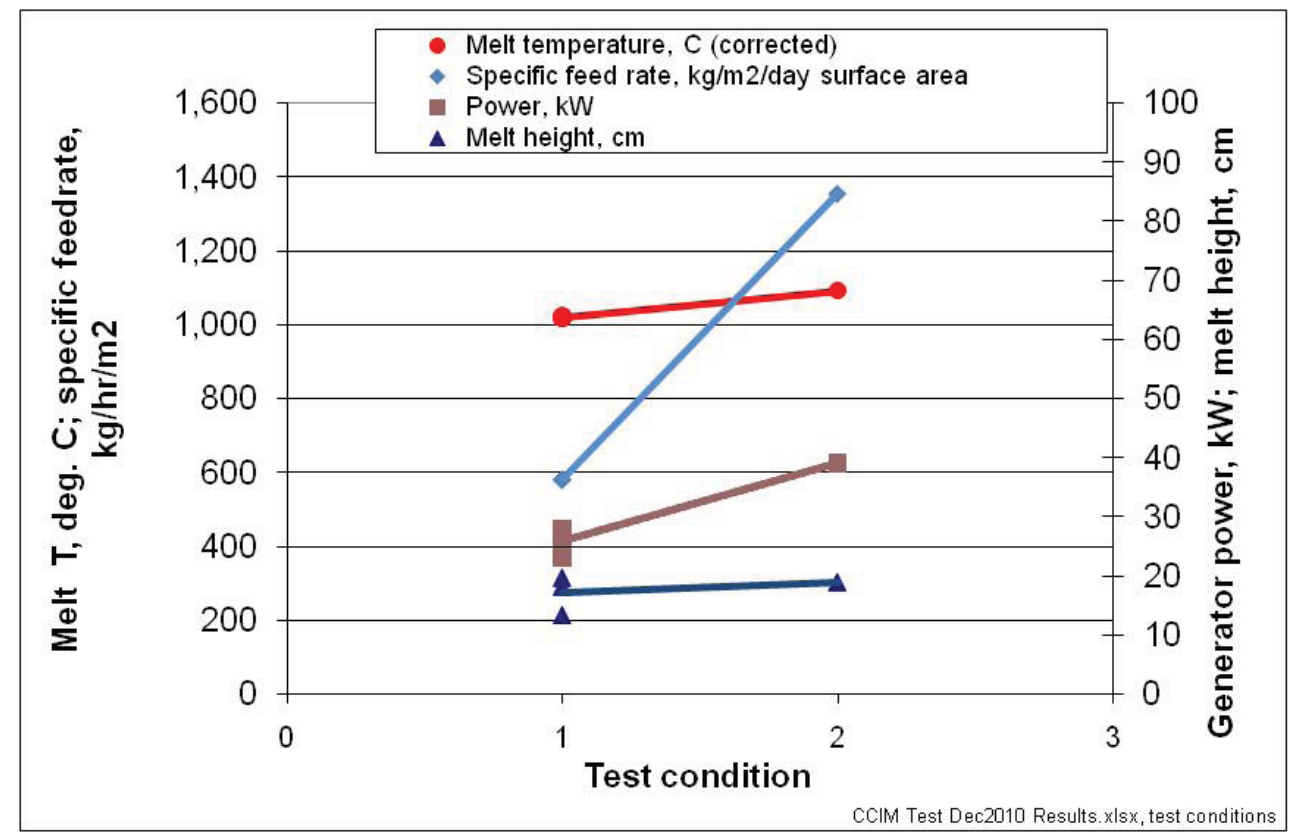

Figure 5-3. Operating conditions during the test.

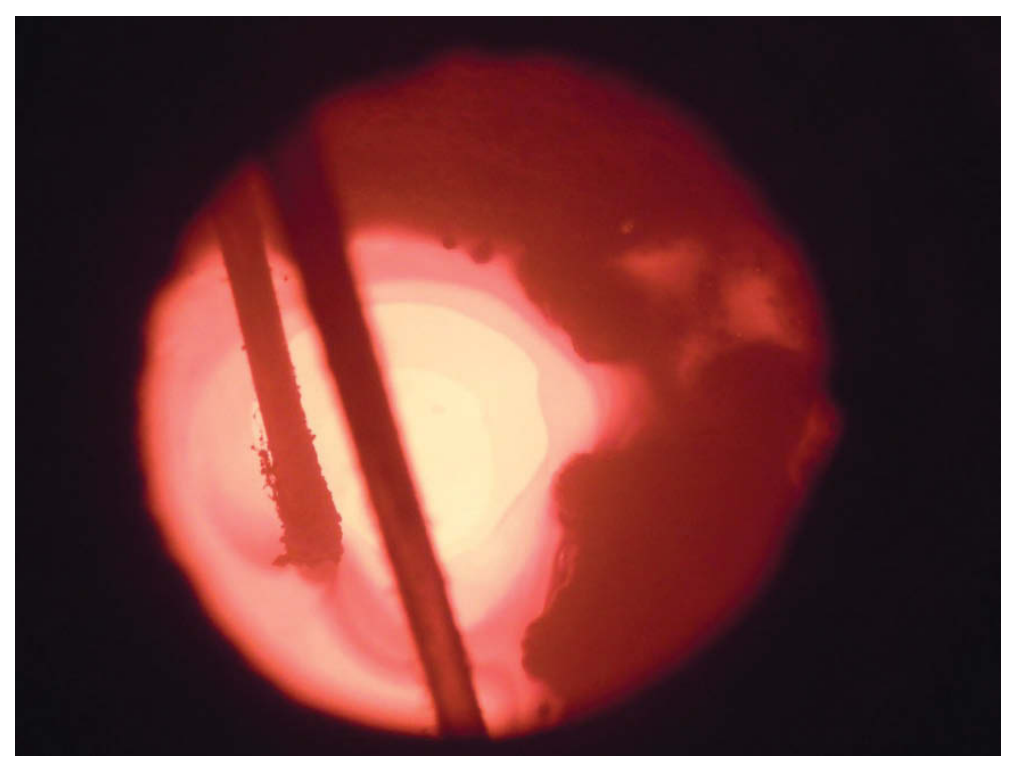

Figure 5-4. View of the partially-covered melt surface through a site port on the melter lid.

Higher cold cap coverage tended to result in melter freeboard gas temperatures below $100^{\circ} \mathrm{C}$, and allowed some bridging of cold cap to occur during melter drains. Lower cold top coverage implied that 
we could increase the feedrate. We adjusted feedrate to maintain the freeboard temperature above $100^{\circ} \mathrm{C}$ (to reduce moisture condensation in the freeboard) and to avoid bridging.

Average melter feedrates for each test condition ranged between $0.63-3.2 \mathrm{~kg} / \mathrm{hr}(0.4-2 \mathrm{~L} / \mathrm{hr})$. The highest feedrate occurred during the Condition 2 , which had a $\sim 60 \%$ cold cap coverage and a high target glass melt temperature $\left(1,100^{\circ} \mathrm{C}\right)$. The lower feedrate occurred for Condition 1 , which has a lower target melt temperature of $1,030^{\circ} \mathrm{C}$, but higher cold cap coverages up to $90 \%$. These feedrates corresponded to specific feedrates that ranged between $581-1,355 \mathrm{~kg} / \mathrm{m}^{2} /$ day.

The specific feedrate, cold cap coverage, and melter freeboard temperatures for the test conditions are shown in Figure 5-5. While we would normally expect that the highest cold cap coverage would occur at the highest feedrate, in this case the lowest cold cap coverage occurred at the highest feedrate, because the highest feedrate occurred for the higher melt temperature. This figure suggests that, because of the lesscomplete cold cap coverage and the higher melter freeboard temperature for the higher melt temperature condition, it may have been possible to further increase the feedrate at the higher melt temperature until the cold cap coverage increased to $\sim 75 \%$.

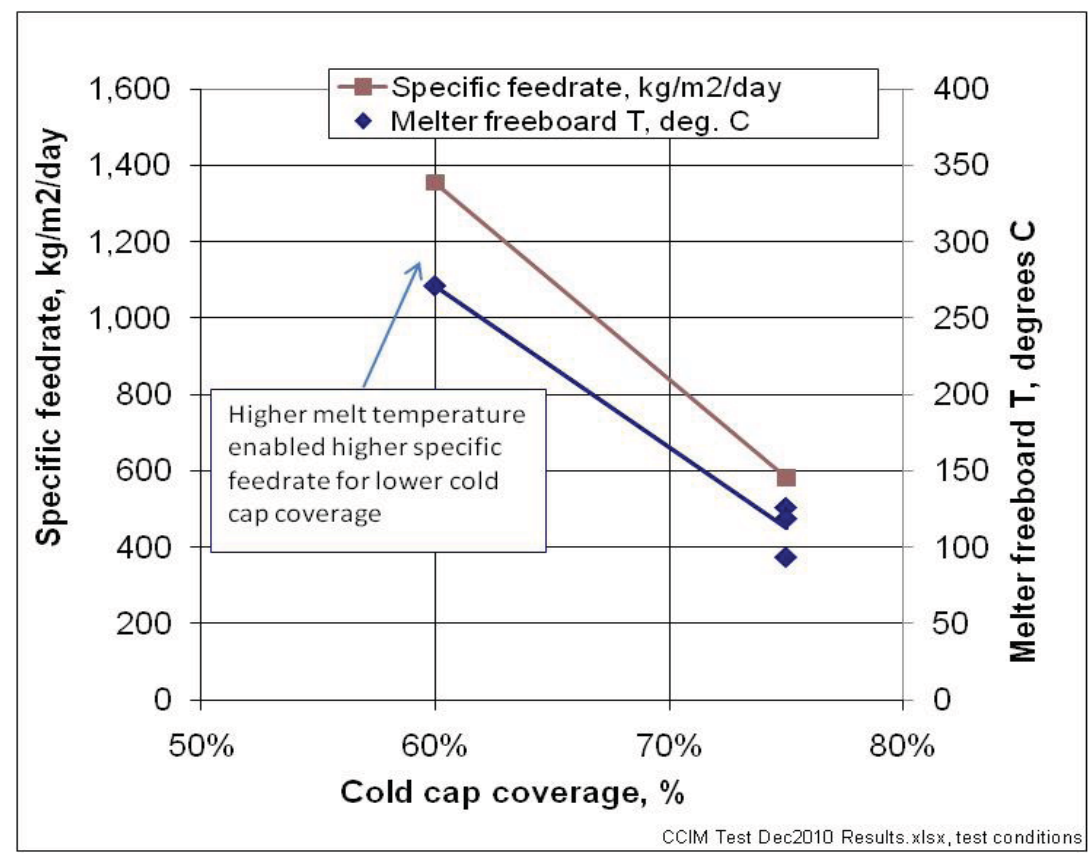

Figure 5-5. Specific feedrate and melter freeboard temperatures at different cold cap coverages.

Some bridging of unmelted cold cap material occurred occasionally, probably due to the small diameter of the melter and the presence of the melt thermocouple (TC) and the air bubbler that penetrated from the melter lid through the cold cap into the molten melt. The inside diameter of this crucible was about $26.7 \mathrm{~cm}$ (10.5 inches). The distances between the melter sidewall and the melt TC and air bubbler were even less. The distance between the TC and the air bubbler was $10 \mathrm{~cm}$ (4 inches), and the distance from the air bubbler (and the TC) and the sidewall was $8.4 \mathrm{~cm}$ (3.3 inches). These relatively short distances provide opportunity for a hardened, crusty cold cap to attach to and then bridge between the TC, bubbler, and sidewall.

When cold cap bridging occurs, then as the molten glass level drops during a melter drain, an air gap can form between the bottom of the bridge and the top of the molten glass. When this occurs, then heat and mass transfer between the molten glass and the bridge (and additional cold feed on top of the bridge) is significantly reduced. This condition results in a lower possible feedrate than would be achievable without cold cap bridging, and needs to be avoided. 


\subsection{Melt Temperature Profile}

The melt temperature was measured using a single, replaceable, $1 / 4$-inch, inconel-sheathed Type K TC that could be raised or lowered so that it provided a representative melt temperature. Figure 5-6 shows a vertical temperature traverse in the melter from the bottom of the crucible to the top of the melt, when the melt depth was just under $22 \mathrm{~cm}$. The melt temperature was relatively constant in the lower half of the melt. The melt temperature TC was typically $6-8 \mathrm{~cm}$ above the bottom of the melter, at a depth where the melt temperature was most constant and less subject to cooling at the very bottom of the melt or at the very top of the melt.

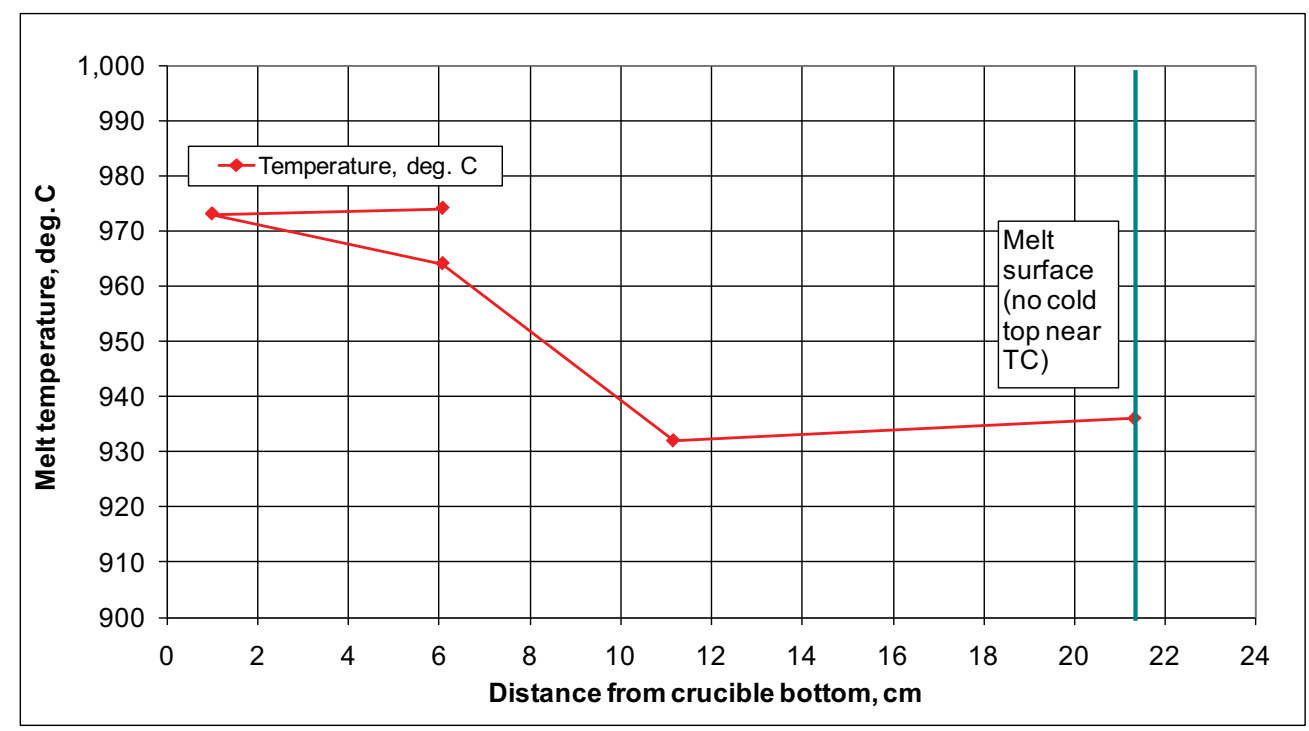

Figure 5-6. Melt temperature vertical traverse. 


\section{Melter Off-gas Emissions}

The off-gas composition was measured at the melter freeboard sample location. Particulate matter PM) concentrations, compositions, and emission rates were measured by manual off-gas sampling at the isokinetic sample location near the outlet of the heated duct. The off-gas measurements included:

- Continuous emissions monitoring for $\mathrm{O}_{2}, \mathrm{CO}_{2}, \mathrm{H}_{2}, \mathrm{CO}, \mathrm{CH}_{4}, \mathrm{THC}, \mathrm{SO}_{2}, \mathrm{NO}$, and $\mathrm{NO}_{\mathrm{x}}$.

- Periodic melter off-gas velocity and temperature measurements according to EPA Methods 1A, 2, and $2 \mathrm{~B}$ for sampling in small-diameter ducts (using a carbon mass balance for off-gas flowrate determination).

- $\quad$ Periodic grab sampling for determining particulate matter (PM) and metals emissions according to EPA Methods 5 and 29, modified for sampling in small diameter ducts.

\subsection{Melter Off-gas Composition and Flowrate}

Table 6-1 and 6-2, and Figures 6-1 through 6-4, show the average CEMS data on both the dry, asmeasured basis, and also normalized to a wet basis, for each test condition. The off-gas concentrations are measured on a dry basis, after moisture in the off-gas is condensed and removed from the sample gas stream. This prevents unwanted moisture condensation in the CEMS sample gas flow control system and in the analyzers. On a dry basis, the off-gas is mostly air that is allowed to leak into the crucible through unavoidable but small gaps in between the crucible tubes above the melt line. Dry-basis $\mathrm{O}_{2}$ levels ranged between 20.5-20.8\%, just below the ambient air $\mathrm{O}_{2}$ concentration of $20.94 \%$. Dry-basis $\mathrm{CO}_{2}$ levels ranged between about $5 \%$ to about $14 \%$. The higher $\mathrm{CO}_{2}$ values occurred at the higher melter feedrate, and when the melter differential pressure was practically zero (instead of slightly negative at about 0.2 inches negative water pressure), so the amount of air inleakage was less. Dry-basis $\mathrm{H}_{2}$ levels ranged under $1 \%$ except for the higher-feedrate, lower-negative-pressure condition when the $\mathrm{H}_{2}$ levels ranged between 1-2\%. Dry-basis $\mathrm{CO}$ and $\mathrm{CH}_{4}$ levels were even lower, ranging from zero to under $30 \mathrm{ppm}$. Dry basis $\mathrm{NO}$ and $\mathrm{NO}_{\mathrm{x}}$ (total $\mathrm{NO}$ and $\mathrm{NO}_{2}$ ) levels ranged typically under 4,000 ppm (lower for the lowerfeedrate condition, and higher for the higher-feedrate, lower-negative-pressure condition).

Table 6-2 and Figures 6-2 and 6-3 show how the concentrations of all those gas species are reduced when the moisture content of the off-gas is accounted for. The moisture content was calculated by a water mass balance to calculate the total flowrate of evaporated water and moisture of oxidation of the sugar in the feed and a carbon mass balance to calculate the total off-gas flowrate using the carbon in the $\mathrm{CO}_{3}$, oxalate $\left(\mathrm{C}_{2} \mathrm{O}_{4}\right)$, and sugar in the feed and the off-gas $\mathrm{CO}_{2}$ measurements according to EPA Method $2 \mathrm{~B}$, which specifies a carbon mass balance. (The off-gas flowrate is also normally measured during the EPA Method 5/29 sampling, but in this test, the off-gas velocity was too small to accurately measure using an S-type pitot tube.)

Reporting both sets of dry and wet-basis off-gas composition data is important because, while the as-measured, dry-basis data are used for process monitoring and control, they do not accurately represent the actual melter off-gas composition, which is more accurately represented by the wet-basis data. This is important when considering such issues as off-gas flammability and $\mathrm{NO}_{\mathrm{x}}$ concentrations, because the actual concentrations, being on a wet basis, are diluted by moisture and are lower than the as-measured (dry basis) values. The actual concentrations of gas species such as $\mathrm{O}_{2}, \mathrm{CO}_{2}, \mathrm{NO}_{\mathrm{x}}, \mathrm{CO}, \mathrm{H}_{2}, \mathrm{SO}_{2}$, and $\mathrm{CH}_{4}$ are lower than the values measured in the CEMS, because the CEMS condenses water from the sample gas prior to analysis. 
Table 6-1. Dry-basis melter off-gas composition.

\begin{tabular}{|c|c|c|c|c|c|c|c|c|c|c|}
\hline \multirow[b]{2}{*}{ Test } & \multirow{2}{*}{$\begin{array}{l}\text { Test } \\
\text { Con- } \\
\text { dition } \\
\end{array}$} & \multirow{2}{*}{$\begin{array}{c}\text { Off-gas } \\
\text { duct T, } \\
{ }^{\circ} \mathrm{C}\end{array}$} & \multicolumn{8}{|c|}{ Off-gas composition, dry bas is } \\
\hline & & & $\mathrm{O}_{2}, \%$ & $\mathrm{CO}_{2}, \%$ & $\mathrm{H}_{2}, \%$ & $\mathrm{CO}, \%$ & $\begin{array}{l}\mathrm{CH}_{4}, \\
\mathrm{ppm}\end{array}$ & $\begin{array}{l}\mathrm{SO}_{2} \\
\mathrm{ppm}\end{array}$ & $\mathrm{NO}, \mathrm{ppm}$ & $\begin{array}{l}\mathrm{NO}_{\mathrm{x}}, \\
\mathrm{ppm}\end{array}$ \\
\hline 3 & 1 & 163 & 20.5 & 5.5 & 0.5 & 0.00 & 20 & 30 & 911 & 2,851 \\
\hline 4 & 1 & 112 & 20.8 & 5.3 & 0.4 & 0.00 & 0 & 70 & 2,183 & 1,981 \\
\hline 5 & 1 & 118 & 20.8 & 4.8 & 0.4 & 0.00 & 0 & 74 & 2,219 & 2,081 \\
\hline 6 & 2 & 174 & 20.7 & 14.3 & 1.4 & 0.01 & 28 & 77 & 3,473 & 3,613 \\
\hline \multicolumn{2}{|c|}{ Averages } & 142 & 20.7 & 7.5 & 0.65 & 0.002 & 12 & 63 & 2,197 & 2,631 \\
\hline \multicolumn{11}{|c|}{$\begin{array}{l}\text { 1. The sampling period includes the time during which the Method } 29 \text { metals and } \\
\text { particulate sampling train and the are collected, and the time between these two } \\
\text { sample collection times. }\end{array}$} \\
\hline \multicolumn{11}{|c|}{$\begin{array}{l}\text { 2. Some } \mathrm{CO} \text { and } \mathrm{CH}_{4} \text { values were slightly negative due to zero drift. These have } \\
\text { been truncated to zero. }\end{array}$} \\
\hline
\end{tabular}

[CCIM Test Dec2010 Results 13Sept current .xlsx]dry CEMS

Table 6-2. Wet-basis melter off-gas flowrate and composition.

\begin{tabular}{|c|c|c|c|c|c|c|c|c|c|c|c|c|c|c|c|c|c|c|c|}
\hline \multirow[b]{3}{*}{ Test } & \multirow{3}{*}{$\begin{array}{r}\text { Test } \\
\text { Con- } \\
\text { dition } \\
\end{array}$} & \multirow{3}{*}{$\begin{array}{l}\text { Evap. } \\
\text { feed } \\
\text { gas } \\
\text { flow } \\
\text { rate, } \\
\text { wscfm }\end{array}$} & \multirow{3}{*}{$\begin{array}{l}\text { Melter } \\
\text { off- } \\
\text { gas } \\
\text { flow } \\
\text { rate, } \\
\text { wscfm }\end{array}$} & \multirow{3}{*}{$\begin{array}{l}\text { Melter } \\
\text { gas } \\
\text { dilution } \\
\text { factor }\end{array}$} & \multicolumn{9}{|c|}{ Off-gas composition, wet basis } & & & \multicolumn{2}{|c|}{$\begin{array}{l}\text { MTECs, wet } \\
\text { basis }\end{array}$} & \multirow{3}{*}{$\begin{array}{c}\mathrm{NO}_{\mathrm{x}} \\
\text { destruc- } \\
\text { tion, \% } \\
\end{array}$} & \multirow{3}{*}{$\begin{array}{c}\mathrm{H} \\
\text { oxida- } \\
\text { tion, } \\
\%\end{array}$} \\
\hline & & & & & \multirow[b]{2}{*}{$\begin{array}{c}\mathrm{O}_{2} \\
\% \\
\end{array}$} & \multirow[b]{2}{*}{$\begin{array}{c}\mathrm{CO}_{2}, \\
\% \\
\end{array}$} & \multirow[b]{2}{*}{$\begin{array}{c}\mathrm{H}_{2}, \\
\%\end{array}$} & \multirow[b]{2}{*}{$\begin{array}{c}\mathrm{CO} \\
\%\end{array}$} & \multirow[b]{2}{*}{$\begin{array}{l}\mathrm{CH}_{4}, \\
\mathrm{ppm}\end{array}$} & \multirow[b]{2}{*}{$\begin{array}{l}\mathrm{SO}_{2}, \\
\mathrm{ppm}\end{array}$} & \multirow[b]{2}{*}{$\begin{array}{l}\mathrm{NO}, \\
\mathrm{ppm}\end{array}$} & \multirow[b]{2}{*}{$\begin{array}{l}\mathrm{NO}_{\mathrm{x}} \\
\mathrm{ppm}\end{array}$} & \multirow[b]{2}{*}{$\begin{array}{c}\mathrm{H}_{2} \mathrm{O}, \\
\%\end{array}$} & \multicolumn{2}{|c|}{ S emission rate } & \multirow[b]{2}{*}{$\begin{array}{l}\mathrm{NO}_{\mathrm{x}} \\
\mathrm{ppm}\end{array}$} & \multirow{2}{*}{$\begin{array}{c}\mathrm{H}_{2} \\
\text { from } \\
\text { sugar, } \\
\% \\
\end{array}$} & & \\
\hline & & & & & & & & & & & & & & $\mathrm{kg} / \mathrm{hr}$ & $\begin{array}{l}\% \text { of S } \\
\text { in feed }\end{array}$ & & & & \\
\hline 3 & 1 & 0.53 & 0.87 & 1.6 & 8.6 & 2.3 & 0.19 & 0.000 & 8 & 13 & 382 & 1,196 & $58 \%$ & 0.000025 & $0.3 \%$ & 17,421 & 0.77 & $93 \%$ & $75 \%$ \\
\hline 4 & 1 & 0.53 & 0.89 & 1.7 & 8.9 & 2.3 & 0.18 & 0.000 & 0 & 30 & 939 & 852 & $57 \%$ & & $.7 \%$ & 17,099 & 0.75 & $\%$ & $76 \%$ \\
\hline 5 & 1 & 51 & 0.86 & 1.7 & 9.4 & 2.2 & 0.17 & 0.000 & 0 & 33 & 1,007 & 944 & $55 \%$ & & $.7 \%$ & 16,390 & 0.72 & & $76 \%$ \\
\hline 6 & 2 & 0.86 & 0.94 & 1.1 & 6.5 & 4.5 & 0.43 & 0.002 & 9 & 24 & 1,093 & 1,138 & $69 \%$ & 0.000052 & $0.2 \%$ & 20,557 & 0.90 & $94 \%$ & $53 \%$ \\
\hline \multicolumn{2}{|c|}{ Averages } & 0.6 & 0.9 & 1.5 & \begin{tabular}{|l|}
8.4 \\
\end{tabular} & 2.82 & 0.24 & 0.001 & 4 & 25 & 855 & 1,032 & $60 \%$ & 0.00 & $0.5 \%$ & 17,867 & 0.78 & $94 \%$ & $70 \%$ \\
\hline \multicolumn{2}{|c|}{ Notes: } & & & & & & & & & & & & & & & & & & \\
\hline \multicolumn{20}{|c|}{$\begin{array}{l}\text { 1. The gas flowrate from the evaporation of the melter feed was estimated assuming that (a) all water evolves as gaseous } \mathrm{H}_{2} \mathrm{O} \text {, (b) all nitrite } \\
\left(\mathrm{NO}_{2}\right) \text { and nitrate }\left(\mathrm{NO}_{3}\right) \text { evolves as } \mathrm{NO}_{2} \text {, (c) all sugar evolves as } \mathrm{CO}_{2} \text { and } \mathrm{H}_{2} \mathrm{O} \text {, and (d) all oxalate evolves as } \mathrm{CO}_{2} \text {. }\end{array}$} \\
\hline \multicolumn{20}{|c|}{$\begin{array}{l}\text { 2. The offgas flowrate was determined by using a carbon mass balance of unity, the melter feedrate and composition, and assuming that all } \\
\text { carbon in the feed evolves to the off-gas as } \mathrm{CO}_{2} \text {. }\end{array}$} \\
\hline \multicolumn{20}{|c|}{$\begin{array}{l}\text { 3. The wet basis off-gas composition was calculated by a water mass balance, assuming all water in the feed evolves as gaseous } \mathrm{H}_{2} \mathrm{O} \text { and } \\
\text { all sugar in the feed evolves as } \mathrm{CO}_{2} \text { and } \mathrm{H}_{2} \mathrm{O} \text {. }\end{array}$} \\
\hline \multicolumn{20}{|c|}{$\begin{array}{l}\text { 4. The Maximum Theoretical Emission Concentration (MTEC) values were calculated using the melter feedrate and composition and the off- } \\
\text { gas flowrate determined using a carbon mass balance of unity. The MTEC for } \mathrm{NO}_{\mathrm{x}} \text { was calculated assuming all nitrate and nitrite in the feed } \\
\text { evolves as } \mathrm{NO}_{\mathrm{x}} \text {. The } \mathrm{H}_{2} \text { MTEC was calculated assuming all } \mathrm{H} \text { in the sugar in the melter feed evolves as } \mathrm{H}_{2} \text {. }\end{array}$} \\
\hline \multicolumn{20}{|c|}{$\begin{array}{l}\text { 5. } \mathrm{NO}_{\mathrm{x}} \text { destruction and } \mathrm{H}_{2} \text { oxidation were calculated by comparing the measured } \mathrm{NO}_{\mathrm{x}} \text { and } \mathrm{H}_{2} \text { concentrations in the off-gas to the } \mathrm{NO}_{\mathrm{x}} \text { and } \\
\mathrm{H}_{2} \text { METCs, assuming nitrate-nitrite- } \mathrm{NO}_{\mathrm{x}} \text { and } \mathrm{H}-\mathrm{H}_{2} \text { mass balance closure of unity. }\end{array}$} \\
\hline
\end{tabular}

[CCIM Test Dec2010 Results 13Sept current .xlsx]wet CEMS 


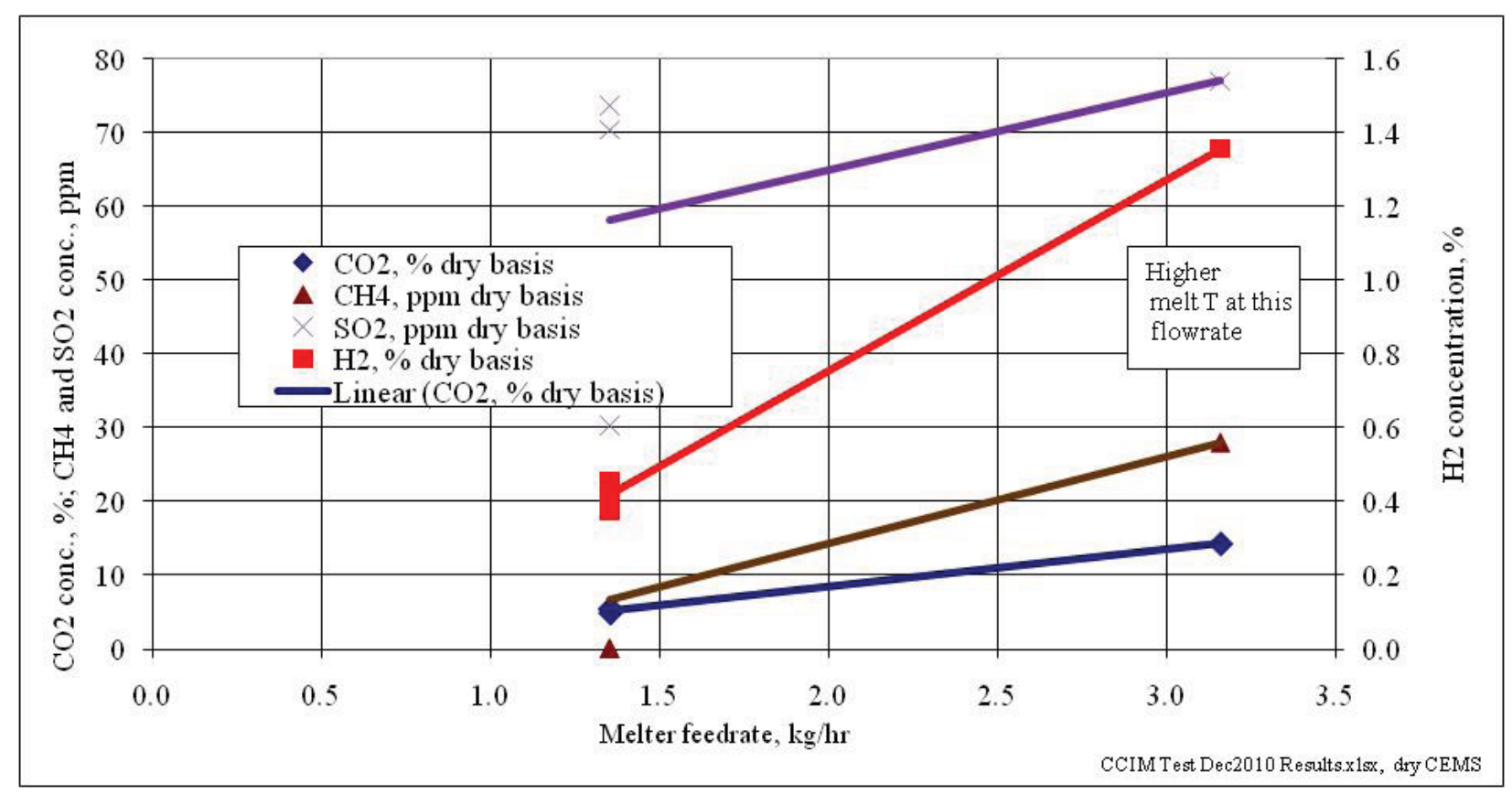

Figure 6-1. Dry-basis $\mathrm{CO} 2, \mathrm{CH} 4, \mathrm{SO} 2$, and $\mathrm{H} 2$ concentrations.

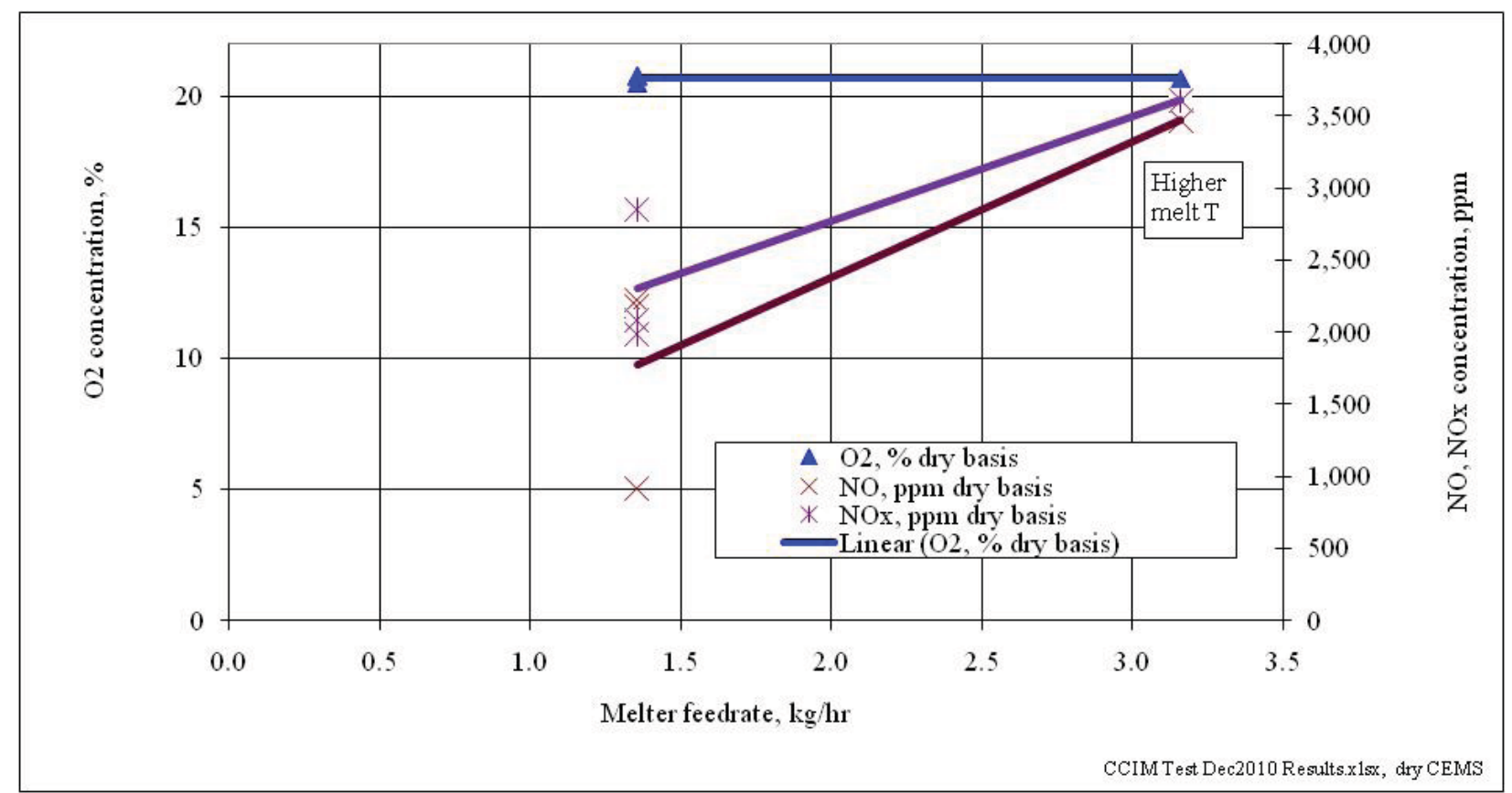

Figure 6-2. Dry-basis O2, NO, and NOx concentrations.

The wet-basis concentrations show that off-gas flammability was not a significant concern, because the $\mathrm{H}_{2}$ concentrations trended less than $0.5 \%$, and levels of other flammable gases $\left(\mathrm{CH}_{4}\right.$ and $\left.\mathrm{CO}\right)$ were in the low ppm range, under $10 \mathrm{ppm}$. The off-gas moisture content ranged between $50-70 \%$. Levels of all of the other gas species are diluted by the moisture in the offgas. In particular, the higher levels of $\mathrm{NO}_{\mathrm{x}}$ on a dry basis for the higher-temperature, lower-inleakage, higher-feedrate test condition are depressed to be more similar to the $\mathrm{NO}_{\mathrm{x}}$ levels for the lower-temperature, lower-feedrate test condition. This is because of the higher moisture content at almost $70 \%$ for the higher feedrate test condition. 


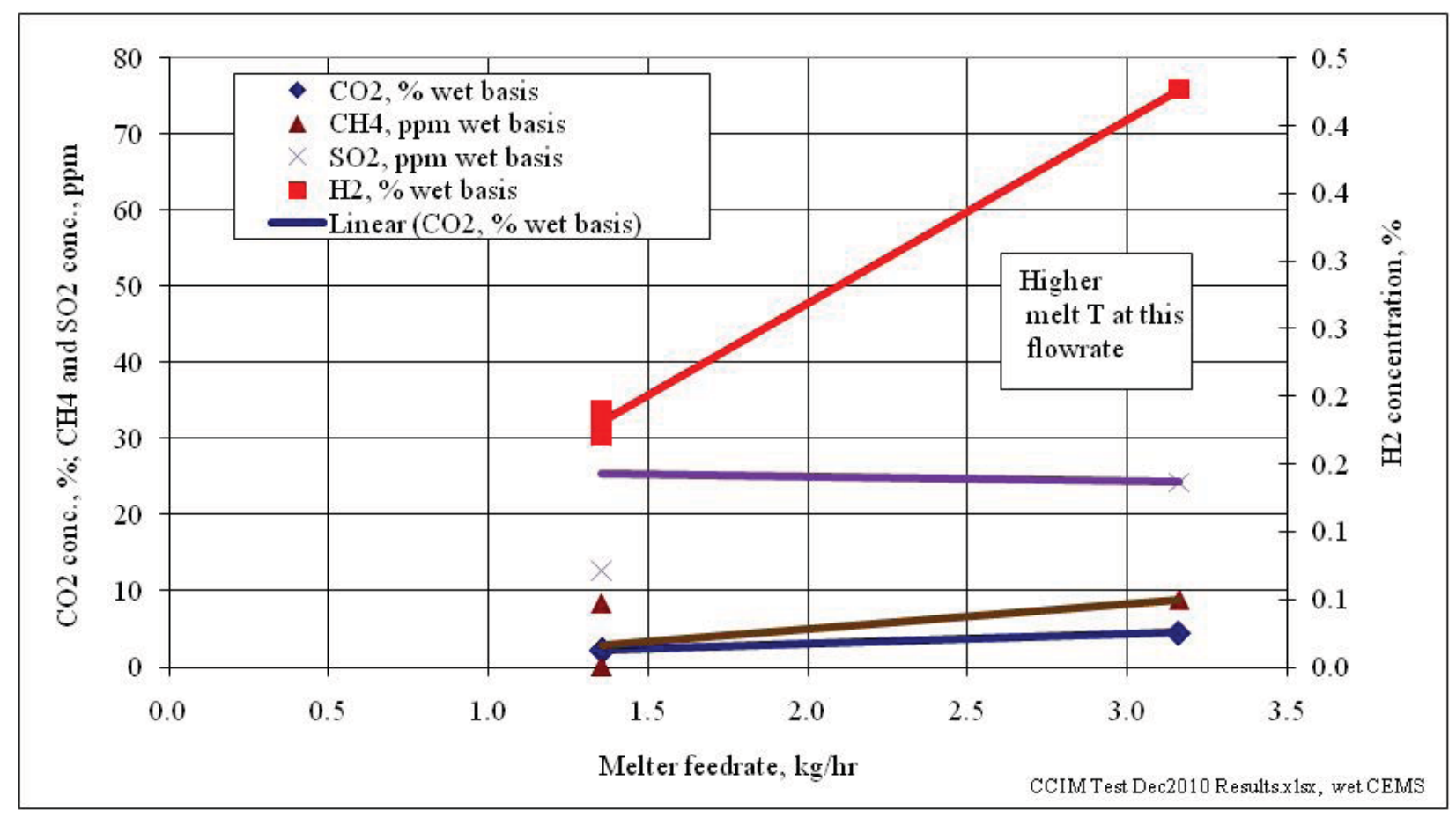

Figure 6-3. Wet-basis $\mathrm{CO} 2, \mathrm{CH} 4, \mathrm{SO} 2$, and $\mathrm{H} 2$ concentrations.

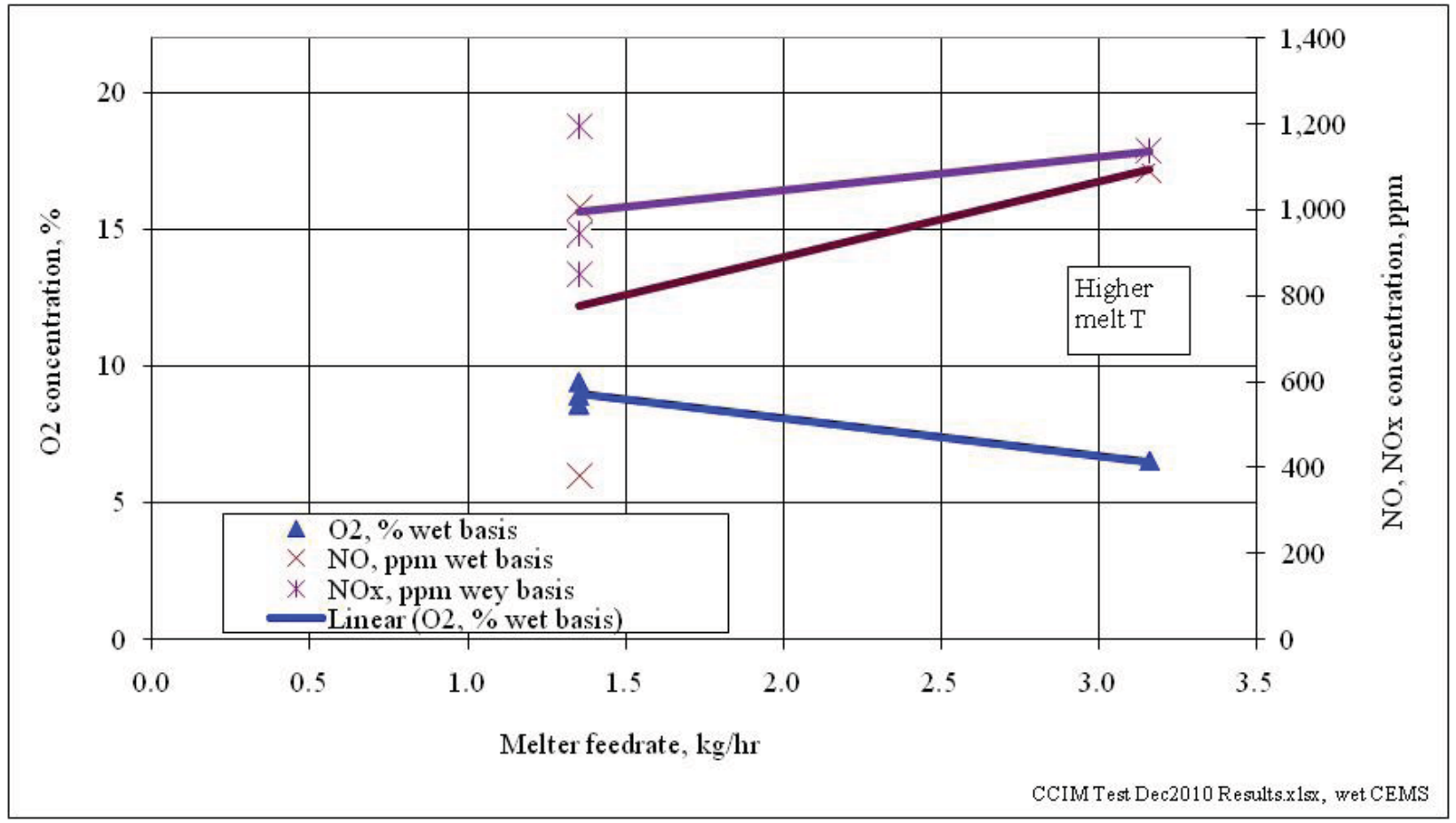

Figure 6-4. Wet-basis O2, NO, and NOx concentrations.

The flowrate of the off-gas that evolved and evaporated from the melter feed ranged between 0.5 and $0.9 \mathrm{wscfm}$ for the two different melter feedrates. The total melter off-gas, including air inleakage and the flowrate of the air bubbler, ranged between about 0.9 to $1 \mathrm{wscfm}$.

The air dilution factor in the off-gas from air inleakage and the bubbler ranged about $1.7 \mathrm{x}$ for the lower-temperature test conditions and about 1.1x for the higher-temperature test condition. The lower air inleakage for the higher-temperature test condition occurred because the melter vacuum (typically maintained at about -0.2 inches water) was allowed approach closer to zero, when the backpressure in the 
off-gas system increased due to moisture condensation in a downstream low point of the off-gas piping. This created a water seal through which the off-gas bubbled, causing a slight backpressure on the melter.

\section{2 $\mathrm{SO}_{4}$ Volatilization, $\mathrm{NO}_{\times}$Destruction, and $\mathrm{H}$ Oxidation}

The off-gas data shows that a small portion of $\mathrm{SO}_{4}$ in the melter feed volatilized to $\mathrm{SO}_{2}$ that was detectable in the off-gas $\mathrm{SO}_{2}$ analyzer. Wet-basis $\mathrm{SO}_{2}$ concentrations averaged about $25 \mathrm{ppm}$. This represented actually a very small amount, averaging about $1 \%$, of the total $\mathrm{S}$ in the feed. Other gaseous $\mathrm{S}$ species, such as $\mathrm{SO}_{3}$, and any particle-phase $\mathrm{S}$ species are not detected by the $\mathrm{SO}_{2}$ analyzer.

$\mathrm{NO}_{\mathrm{x}}$ destruction was calculated to be a surprisingly high $94 \%$ on average. The $\mathrm{NO}_{\mathrm{x}}$ destruction was determined by calculating the Maximum Theoretical Emission Concentration (MTEC) on a wet basis in the offgas, using the nitrate and nitrite concentrations in the melter feed, the melter feedrate, and the offgas flowrate. The NOx MTEC values ranged between about 16,000-21,000 ppm on a wet basis. The $\mathrm{NO}_{\mathrm{x}}$ destruction values were calculated using the measured $\mathrm{NO}_{\mathrm{x}}$ concentrations and the calculated $\mathrm{NO}_{\mathrm{x}}$ MTEC values. This level of $\mathrm{NO}_{\mathrm{x}}$ destruction is higher than determined in prior test programs, such as the Off-gas System Evaluation Test performed in the CCIM test system for the Advanced Remediation Technology Program (Soelberg 2009). $\mathrm{NO}_{\mathrm{x}}$ destruction in that test averaged about 33\%. If additional iron-phosphate melter testing is done, then $\mathrm{NO}_{\mathrm{x}}$ destruction should be re-evaluated at that time.

Mass balances were done to estimate the degree of oxidation of the $\mathrm{H}$ in the sugar reductant, like were done to estimate $\mathrm{NO}_{\mathrm{x}}$ destruction. The $\mathrm{H}_{2}$ MTECs were estimated to range between $0.7-0.9 \%$ on a wet basis. $\mathrm{H}$ oxidation was estimated to range between about $50-80 \%$ using the measured wet-basis $\mathrm{H}_{2}$ levels and the $\mathrm{H}_{2}$ MTECs.

\subsection{Melter Off-gas Particulate and Metals Emissions}

Table 6-3 shows the concentration and emission rate measurements for total PM and each metal that was analyzed in the melter off-gas samples. These results include analysis of both gas-phase and aerosolphase metals in the off-gas. The total PM concentration ranged between $29-89 \mathrm{mg} / \mathrm{wscf}$ (mg per wet standard cubic foot). The total PM emission rate ranged between 1.5-5 gm/hr. This PM emission rate corresponds to $0.24-0.5 \%$ of the glass production rate.

The metals analyzed in the feed and the glass were analyzed in the off-gas PM, except for Si. Si cannot be analyzed for in the off-gas samples because a glass-fiber filter that is $100 \% \mathrm{SiO}_{2}$ is used in the Method 5/29 sample train to capture solid-phase PM. This filter is designed and operated to capture $99.97 \%$ of particulate matter of 0.3 micron diameter. Any metal vapor, volatilized metals, or fine particulate that pass through this filter is scrubbed in acidified nitric acid/hydrogen peroxide impingers downstream of the filter. In this way, the Method 5/29 sample train is used measure off-gas PM and metals emissions, regardless of whether metals are solid-phase or gaseous.

A single analysis of the wet scrubber solution was performed. Prior to analysis the scrub solution was filtered, so the analysis shown in Table 6-4 represents only dissolved species in the scrub solution. The highest concentrations of dissolved solids in the scrub solution were, not surprisingly, for $\mathrm{NO}_{3}, \mathrm{SO}_{3}$, and $\mathrm{Na}_{2} \mathrm{O}$. Using the estimated scrubber solution volume and density, the mass of the elements dissolved in the scrub solution was determined. The total amount of the dissolved elements was only 1.326 grams, which is well under a fraction of a percent of the total input glass mass. The masses of all elements detected in the scrub solution are also all less than a fraction of a percent of the input masses of those elements. 
Table 6-3. Melter off-gas particulate and metals concentrations and emission rates.

\begin{tabular}{|c|c|c|c|c|c|c|}
\hline & \multirow[b]{2}{*}{ Units } & \multicolumn{4}{|c|}{ Off-gas sample train test number } & \multirow[b]{2}{*}{ Averages } \\
\hline & & 3 & 4 & 5 & 6 & \\
\hline Test condition & & 1 & 1 & 1 & 2 & -- \\
\hline Total PM concentration & $\mathrm{mg} /$ wscf & 59.8 & 32.9 & 29.4 & 88.8 & 53 \\
\hline Total PM concentration & $\mathrm{mg} / \mathrm{wncm}$ & 1,692 & 931 & 832 & 2,513 & 1,492 \\
\hline Total PM emission rate & $\mathrm{gm} / \mathrm{hr}$ & 3.12 & 1.76 & 1.52 & 5.0 & 2.9 \\
\hline Glass input rate & $\mathrm{kg} / \mathrm{hr}$ & 0.62 & 0.62 & 0.62 & 1.45 & 0.8 \\
\hline Total solids split to off-gas & $\%$ & 0.50 & 0.28 & 0.24 & 0.35 & 0.34 \\
\hline Metals concentrations & ug/wscf & & & & & \\
\hline Sulfur & & $28,596.82$ & $16,685.79$ & $6,749.60$ & $41,264.30$ & 23,324 \\
\hline Aluminum & & $1,167.60$ & 907.20 & 330.13 & 913.17 & 829.5 \\
\hline Bismuth & & 651.94 & 552.02 & 150.26 & 953.56 & 576.9 \\
\hline Boron & & 521.42 & 60.07 & 30.63 & 70.55 & 170.7 \\
\hline Calcium & & 847.42 & 284.99 & 269.29 & 182.29 & 396.0 \\
\hline Cesium & & 271.87 & 123.14 & 36.35 & 213.26 & 161.2 \\
\hline Chromium & & 253.89 & 122.66 & 38.64 & 327.09 & 185.6 \\
\hline Iron & & $2,061.20$ & $1,736.65$ & 417.17 & $3,697.25$ & $1,978.1$ \\
\hline Lanthanum & & 172.33 & 106.47 & 30.96 & 166.77 & 119.1 \\
\hline Phosphorus & & $2,252.64$ & $2,248.39$ & 623.93 & $3,331.05$ & $2,114.0$ \\
\hline Potassium & & 878.91 & 392.16 & 197.26 & 716.56 & 546.2 \\
\hline Rhenium & & $1,360.70$ & 630.24 & 177.93 & 679.25 & 712.0 \\
\hline Sodium & & $7,294.01$ & $5,425.08$ & $1,702.99$ & $11,656.78$ & 6,520 \\
\hline Zinc & & $1,221.09$ & 920.85 & 273.89 & $2,176.76$ & $1,148.1$ \\
\hline Zirconium & & 134.01 & 69.81 & 18.31 & 105.61 & 81.9 \\
\hline Iodide & & 5.86 & 1.68 & 1.39 & 0.86 & 2.45 \\
\hline Floride & & 69.88 & 6.77 & 2.31 & 6.24 & 21.3 \\
\hline Chloride & & 38.84 & 4.75 & 2.11 & 6.61 & 13.1 \\
\hline Totals & & 47,800 & 30,279 & $11,053.2$ & 66,468 & 38,900 \\
\hline Sum metals, $\%$ of total PM & $\%$ & $80 \%$ & $92 \%$ & $38 \%$ & $75 \%$ & $74 \%$ \\
\hline Metals emission rates & $\mathrm{mg} / \mathrm{hr}$ & & & & & \\
\hline Sulfur & & $1,494.97$ & 892.34 & 348.80 & $2,330.76$ & $1,266.72$ \\
\hline Aluminum & & 61.04 & 48.52 & 17.06 & 51.58 & 44.55 \\
\hline Bismuth & & 34.08 & 29.52 & 7.77 & 53.86 & 31.31 \\
\hline Boron & & 27.26 & 3.21 & 1.58 & 3.98 & 9.01 \\
\hline Calcium & & 44.30 & 15.24 & 13.92 & 10.30 & 20.94 \\
\hline Cesium & & 14.21 & 6.59 & 1.88 & 12.05 & 8.68 \\
\hline Chromium & & 13.27 & 6.56 & 2.00 & 18.48 & 10.08 \\
\hline Iron & & 107.75 & 92.87 & 21.56 & 208.83 & 107.76 \\
\hline Lanthanum & & 9.01 & 5.69 & 1.60 & 9.42 & 6.43 \\
\hline Phosphorus & & 117.76 & 120.24 & 32.24 & 188.15 & 114.60 \\
\hline Potassium & & 45.95 & 20.97 & 10.19 & 40.47 & 29.40 \\
\hline Rhenium & & 71.13 & 33.70 & 9.19 & 38.37 & 38.10 \\
\hline Sodium & & 381.31 & 290.13 & 88.00 & 658.42 & 354.47 \\
\hline Zinc & & 63.84 & 49.25 & 14.15 & 122.95 & 62.55 \\
\hline Zirconium & & 7.01 & 3.73 & 0.95 & 5.97 & 4.41 \\
\hline Iodide & & 0.31 & 0.09 & 0.07 & 0.05 & 0.13 \\
\hline Floride & & 3.65 & 0.36 & 0.12 & 0.35 & 1.12 \\
\hline Chloride & & 2.03 & 0.25 & 0.11 & 0.37 & 0.69 \\
\hline \begin{tabular}{|l|} 
Totals \\
\end{tabular} & & 2,499 & 1,619 & 571 & 3,754 & 2,111 \\
\hline \multicolumn{7}{|l|}{ Notes: } \\
\hline \multicolumn{7}{|c|}{ 1. Off-gas metals concentrations and emission rates from Test America } \\
\hline \multicolumn{7}{|c|}{ 2. Italic values are detection limit values for elements that were not detected. } \\
\hline $\begin{array}{l}\text { 3. The initial mass of the sta } \\
\text { are not included in these cal }\end{array}$ & glass, and & $\begin{array}{l}\text { ass of der } \\
\text { e calcula }\end{array}$ & ecovere & e melt & oard an & f-gas pipe, \\
\hline
\end{tabular}


Table 6-4. Analysis of the off-gas scrub solution following the test.

\begin{tabular}{|c|c|c|c|c|c|c|c|}
\hline $\begin{array}{l}\text { Sample } \\
\text { ID }\end{array}$ & \multicolumn{2}{|c|}{ CCIM-FEP-1030 } & \multirow[b]{2}{*}{ Element } & \multirow[b]{2}{*}{$\begin{array}{c}\text { mole } \\
\text { weight } \\
\end{array}$} & \multirow[b]{2}{*}{$\begin{array}{l}\text { Concen- } \\
\text { tration, wt } \%\end{array}$} & \multirow[b]{2}{*}{$\begin{array}{c}\text { Elemental } \\
\text { mass, } g\end{array}$} & \multirow[b]{2}{*}{$\begin{array}{c}\% \text { of input } \\
\text { mass }\end{array}$} \\
\hline Oxide & $\begin{array}{c}\text { mole } \\
\text { weight }\end{array}$ & $\begin{array}{l}\text { Concen- } \\
\text { tration, } \\
\mathrm{wt}^{0} \%\end{array}$ & & & & & \\
\hline $\mathrm{A} 12 \mathrm{O} 3$ & 101.96 & 0.019 & Al & 26.982 & 0.010 & 0.019 & $0.00051 \%$ \\
\hline $\mathrm{B} 2 \mathrm{O} 3$ & 69.62 & 0.0030 & B & 10.811 & 0.00092 & 0.0018 & $0.0029 \%$ \\
\hline Bi2O3 & 465.96 & 0.00018 & $\mathrm{Bi}$ & 208.98 & 0.00016 & 0.00031 & $0.000036 \%$ \\
\hline $\mathrm{C} 2 \mathrm{O} 4$ & 92 & DL & $\mathrm{C} 2 \mathrm{O} 4$ & 92 & DL & DL & DL \\
\hline $\mathrm{CaO}$ & 56.08 & 0.007 & $\mathrm{Ca}$ & 40.078 & 0.005 & 0.0090 & $0.0021 \%$ \\
\hline $\mathrm{Cl}$ & 35.45 & 0.012 & $\mathrm{Cl}$ & 35.453 & 0.012 & 0.024 & -- \\
\hline $\mathrm{Cr} 2 \mathrm{O} 3$ & 151.99 & 0.00097 & $\mathrm{Cr}$ & 51.996 & 0.00066 & 0.0013 & $0.00013 \%$ \\
\hline $\mathrm{Cs} 2 \mathrm{O}$ & 281.84 & 0.00094 & $\mathrm{Cs}$ & 132.92 & 0.00089 & 0.0017 & $0.0025 \%$ \\
\hline $\mathrm{F}$ & 19.00 & DL & $\mathrm{F}$ & 18.998 & $\mathrm{DL}$ & DL & DL \\
\hline $\mathrm{Fe} 2 \mathrm{O} 3$ & 159.69 & 0.050 & $\mathrm{Fe}$ & 55.845 & 0.035 & 0.067 & $0.0025 \%$ \\
\hline $\mathrm{I}$ & 128.90 & 0.0035 & $\mathrm{I}$ & 128.9 & 0.0035 & 0.0067 & $0.026 \%$ \\
\hline $\mathrm{K} 2 \mathrm{O}$ & 94.20 & 0.0049 & $\mathrm{~K}$ & 39.098 & 0.0041 & 0.0078 & $0.0017 \%$ \\
\hline $\mathrm{La} 2 \mathrm{O} 3$ & 325.82 & 0.00072 & $\mathrm{La}$ & 138.91 & 0.00061 & 0.0012 & $0.00039 \%$ \\
\hline $\mathrm{NO} 2$ & 46 & DL & $\mathrm{NO} 2$ & 46 & DL & DL & DL \\
\hline NO3 & 62 & 0.29 & NO3 & 62 & 0.29 & 0.56 & -- \\
\hline $\mathrm{Na} 2 \mathrm{O}$ & 61.98 & 0.074 & $\mathrm{Na}$ & 22.99 & 0.055 & 0.10 & $0.0011 \%$ \\
\hline $\mathrm{P} 2 \mathrm{O} 5$ & 143.95 & 0.0067 & $\mathrm{P}$ & 31.974 & 0.0030 & 0.0057 & $0.000063 \%$ \\
\hline $\mathrm{Re} 2 \mathrm{O} 7$ & 484.42 & 0.0028 & Re & 186.21 & 0.0022 & 0.0041 & $0.042 \%$ \\
\hline SO3 & 80.07 & 0.23 & S & 32.065 & 0.18 & 0.35 & $0.032 \%$ \\
\hline $\mathrm{SiO} 2$ & 60.09 & 0.013 & $\mathrm{Si}$ & 28.086 & 0.012 & 0.023 & $0.0015 \%$ \\
\hline $\mathrm{ZnO}$ & 81.38 & 0.026 & $\mathrm{Zn}$ & 65.38 & 0.041 & 0.079 & $0.0055 \%$ \\
\hline $\mathrm{ZrO} 2$ & 123.22 & 0.000026 & $\mathrm{Zr}$ & 91.224 & 0.000039 & 0.000074 & $0.000034 \%$ \\
\hline Totals & & 0.74 & & & 0.66 & 1.26 & $0.0039 \%$ \\
\hline \multicolumn{8}{|l|}{ Notes: } \\
\hline \multicolumn{8}{|c|}{$\begin{array}{l}\text { 1. The scrub solution sample was filtered prior to analysis, so any undissolved solids are } \\
\text { not included in the analysis. }\end{array}$} \\
\hline \multicolumn{6}{|c|}{ 2. The total volume of the post-test scrub solution was: } & \multicolumn{2}{|c|}{190 L. } \\
\hline \multicolumn{6}{|c|}{ 3. Assume a density that accounts for the dissolved solids: } & 1.007 & $\mathrm{~g} / \mathrm{ml}$. \\
\hline 4. $\mathrm{DL}=$ & Detection & limit. & & & & & \\
\hline
\end{tabular}

[CCIM Test Dec2010 Results 16Sept1.xlsx]Scrubber Solution (wt\%) 


\section{Product Glass Characterization}

While the melter feed was continuous during the test, glass draining was semi-continuous, performed for short durations of typically 5-10 minutes when the melt level was high enough. Figure 7-1 shows molten glass being drained through the bottom drain assembly during one of the nine glass drains of this test. The molten glass falls about 1-2 feet into either a stainless steel metal pan, a stainless steel sample cup, or a pan with water.

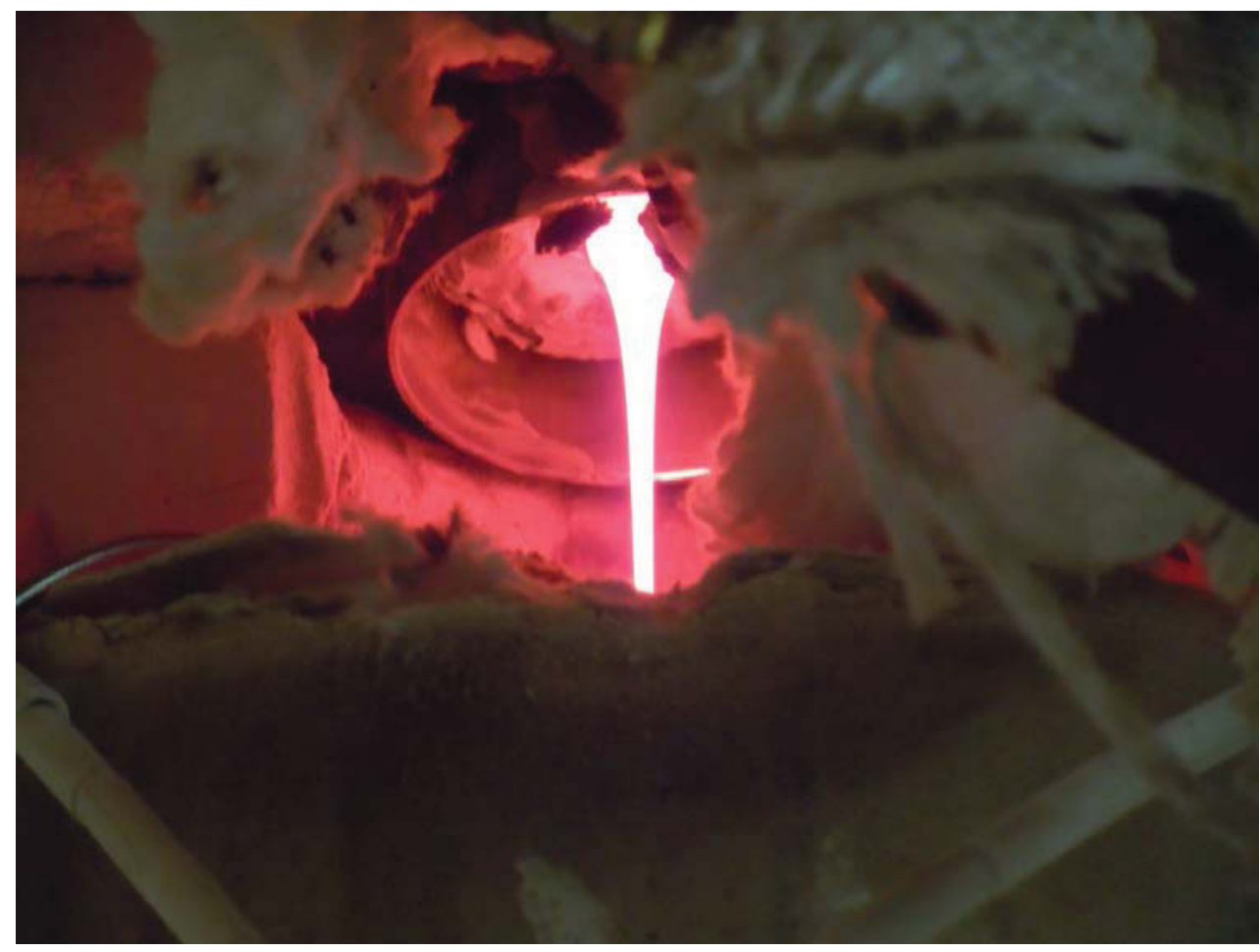

Figure 7-1. Molten glass draining from the melter through the bottom drain.

Figure 7-2 shows the three different types of glass samples that can be collected using the methods described above. The bulk of the drained glass, typically ranging between $1-5 \mathrm{~kg}$, forms a cooled "pancake" in the metal pan. Upon cooling, this glass is weighed and then archived or sampled for analysis. This mass of glass typically cools quickly, and is cool enough to handle within an hour. The stainless steel cup is used to collect discrete, even faster-cooled samples for sample analysis. This mass of glass, typically less than a few hundred grams, cools within 10 minutes for weighing and sample collection. Glass that is fritted into a pan containing cool water is generally limited to less than about 100 $\mathrm{g}$, but is fast-quenched within seconds and can be handled immediately after collection.

The glass had a nearly-black, obsidian-like look, and broke into sharp fragments when fast-cooled. The surfaces were shiny; the surfaces of broken fragments were more shiny than the surfaces of unbroken pancake pieces. These characteristics are similar to those observed for borosilicate glasses. 


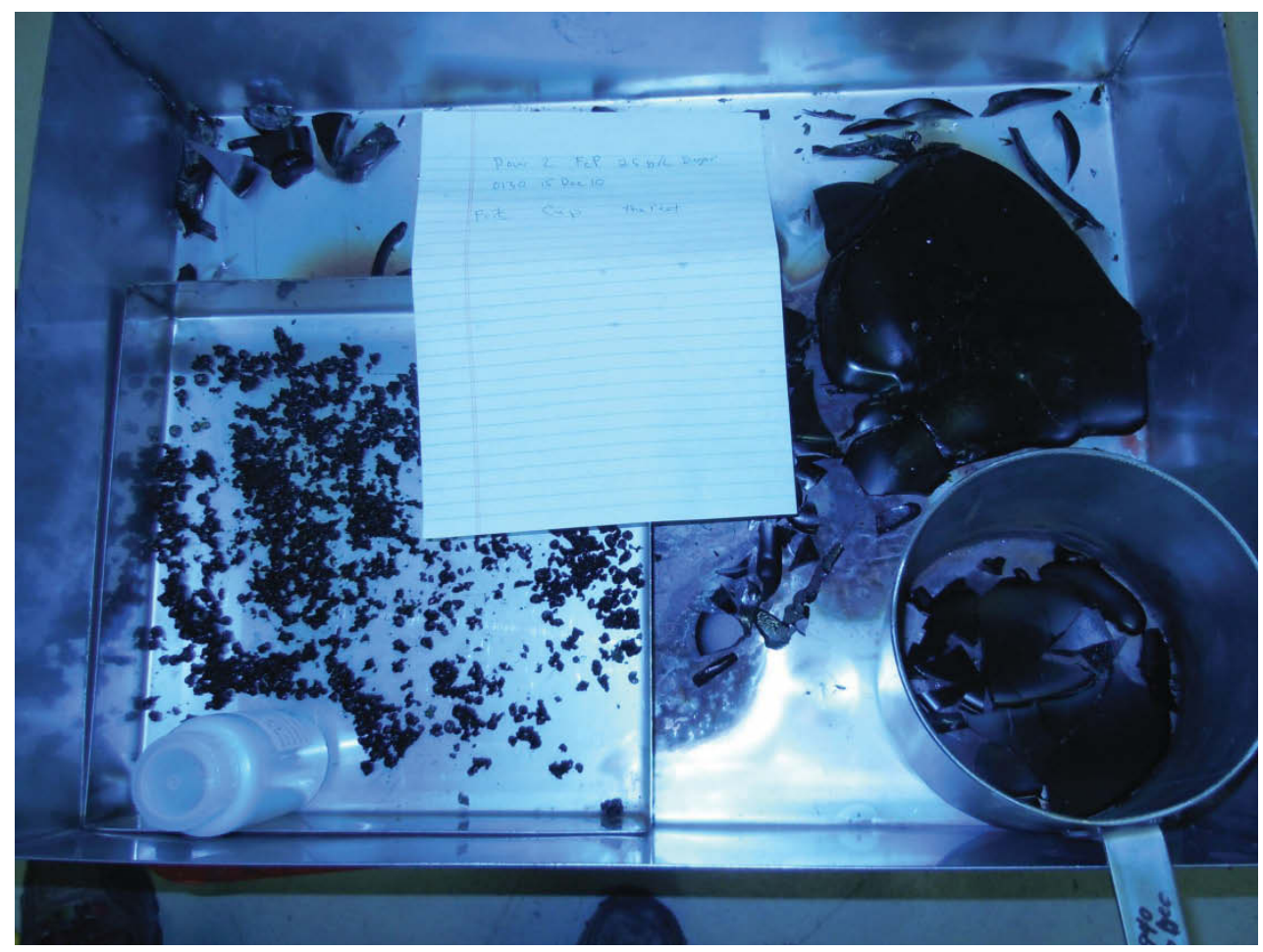

Figure 7-2. Examples of glass samples collected for archiving or analysis in a stainless steel pan, a smaller stainless steel sample cup, or fritted into water and then dried.

Glass samples were collected from the starter glass and the glass drains for analysis. Samples were analyzed by SRNL for density, elemental composition, iron reduction/oxidation ratio (REDOX, or $\mathrm{Fe}^{+2} / \mathrm{Fe}_{\text {total }}$ ), and PCT durability. Cs and Re were analyzed by inductively-coupled plasma mass spectrometry (ICP-MS) to provide the most sensitive practical detection limits for these spiked elements. ICP-atomic absorption spectrometry (ICP-AES) was used for the other elements. For the ICP-AES analysis, a peroxide fusion was done, followed by lithium metaborate digestions. For the ICP-MS analysis, a mixed acid digestion was used for $\mathrm{Cs}$, and an inverse aqua regia digestion was used for Re.

Product glass PCT analyses were done at SRNL on the as-received, relatively fast-cooled glass cup samples. PCT analyses were also done with portions of the glass samples that were re-melted in the laboratory and then slow-cooled following a controlled-centerline-cooling (CCC) history.

Product glass samples were also analyzed at PNNL for crystalline phases using x-ray diffraction (XRD) and for durability using the VHT. VHT analyses were done on both as-received samples and on portions of the samples that were re-melted and then slow-cooled via the CCC cooling history.

For corroboration, product glass samples were also sent to MS\&T for various analyses. These samples were analyzed at MO-SCI for elemental composition using X-ray fluorescence (XRF) and for durability using the VHT on as-received and CCC-treated glass samples.

\subsection{Product Glass Composition}

Table 7-1 shows the analytical results from the SRNL glass composition analyses, on an oxide basis. The total weight $\%$ values for the samples are near $100 \mathrm{wt} \%$, indicating that the analyses are representative of the actual composition. The measured concentrations of most oxides agree within $10 \%$ of the target values. The measured concentrations of $\mathrm{Cr}_{2} \mathrm{O}_{3}, \mathrm{~K}_{2} \mathrm{O}, \mathrm{La}_{2} \mathrm{O}_{3}$ averaged within $20 \%$ of their respective target values. The average measured $\mathrm{Re}_{2} \mathrm{O}_{7}$ concentration was $62.5 \%$ less than the target 
value, presumably due to rounding error and volatilization (more on this in the mass balance section). The average measured $\mathrm{SO}_{3}$ concentration was $24 \%$ less than the target value (more on this in the mass balance section).

Table 7-1. Oxide composition of the product glasses.

\begin{tabular}{|c|c|c|c|c|c|c|c|c|c|c|c|c|}
\hline \multirow[b]{3}{*}{ Oxide } & \multirow{3}{*}{\multicolumn{2}{|c|}{ Target }} & \multicolumn{9}{|c|}{ Sample glass drain composition, wt $\%$} & \multirow{3}{*}{$\begin{array}{c}\text { Average } \\
\% \text { diff. } \\
\text { from target } \\
\text { comp. }\end{array}$} \\
\hline & & & $1031 \mathrm{~A}$ & 1045 & 1053 & 1056B & $1058 \mathrm{~B}$ & 1069B & 1073B & $1074 \mathrm{~A}$ & \multirow{2}{*}{$\begin{array}{c}\text { Average } \\
\text { compo- } \\
\text { sition }\end{array}$} & \\
\hline & & & $\begin{array}{l}\text { starter } \\
\text { glass }\end{array}$ & cup 1 & cup 3 & cup 4 & cup 5 & cup 8 & cup 9 & $\begin{array}{c}\text { mined } \\
\text { contents }\end{array}$ & & \\
\hline $\mathrm{A} 12 \mathrm{O} 3$ & 13.21 & & 12.69 & 13.01 & 13.13 & 13.10 & 13.03 & 13.44 & 13.28 & 13.55 & 13.15 & $-0.4 \%$ \\
\hline B2O3 & 0.03 & $<$ & 0.10 & 0.10 & 0.10 & 0.10 & 0.10 & 0.10 & 0.10 & 0.10 & 0.10 & -- \\
\hline Bi2O3 & 1.77 & & 1.78 & 1.73 & 1.75 & 1.72 & 1.72 & 1.78 & 1.80 & 1.87 & 1.77 & $-0.1 \%$ \\
\hline $\mathrm{CaO}$ & 1.06 & & 1.11 & 1.10 & 1.07 & 1.08 & 1.09 & 1.10 & 1.11 & 1.11 & 1.10 & $3.4 \%$ \\
\hline $\mathrm{Cl}$ & 0.04 & & -- & -- & -- & -- & -- & -- & -- & -- & -- & -- \\
\hline $\mathrm{Cr} 2 \mathrm{O} 3$ & 2.70 & & 2.49 & 2.21 & 2.27 & 2.27 & 2.27 & 2.02 & 2.26 & 2.09 & 2.24 & $-17.2 \%$ \\
\hline $\mathrm{Cs} 2 \mathrm{O}$ & 0.13 & & 0.14 & 0.13 & 0.17 & 0.14 & 0.13 & 0.13 & 0.13 & 0.14 & 0.14 & $6.7 \%$ \\
\hline $\mathrm{F}$ & 0.16 & & -- & -- & -- & -- & -- & -- & -- & -- & -- & -- \\
\hline $\mathrm{Fe} 2 \mathrm{O} 3$ & 7.10 & & 7.41 & 7.21 & 7.18 & 7.23 & 7.09 & 7.01 & 7.00 & 7.12 & 7.16 & $0.8 \%$ \\
\hline I & 0.10 & $<$ & 0.10 & 0.10 & 0.10 & 0.10 & 0.10 & 0.10 & 0.10 & 0.10 & 0.10 & -- \\
\hline $\mathrm{K} 2 \mathrm{O}$ & 0.78 & & 0.84 & 0.90 & 0.89 & 0.94 & 0.93 & 0.93 & 0.93 & 0.98 & 0.92 & $17.6 \%$ \\
\hline $\mathrm{La} 2 \mathrm{O} 3$ & 0.71 & & 0.69 & 0.59 & 0.59 & 0.56 & 0.57 & 0.60 & 0.60 & 0.60 & 0.60 & $-15.5 \%$ \\
\hline $\mathrm{Na} 2 \mathrm{O}$ & 20.03 & & 19.37 & 19.64 & 19.78 & 19.91 & 19.91 & 19.71 & 20.18 & 20.12 & 19.83 & $-1.0 \%$ \\
\hline $\mathrm{P} 2 \mathrm{O} 5$ & 38.06 & & 38.13 & 38.47 & 39.27 & 38.82 & 38.59 & 38.93 & 38.82 & 39.50 & 38.82 & $2.0 \%$ \\
\hline $\mathrm{Re} 2 \mathrm{O} 7$ & 0.03 & & 0.02 & 0.01 & 0.01 & 0.01 & 0.01 & 0.01 & 0.01 & 0.01 & 0.01 & $-62.5 \%$ \\
\hline $\mathrm{SO} 3$ & 4.37 & & 3.53 & 3.32 & 3.51 & 3.52 & 3.51 & 3.07 & 2.98 & 3.12 & 3.32 & $-24.0 \%$ \\
\hline $\mathrm{SiO} 2$ & 5.58 & & 5.96 & 5.79 & 5.62 & 5.59 & 5.50 & 5.56 & 5.64 & 5.62 & 5.66 & $1.4 \%$ \\
\hline $\mathrm{ZnO}$ & 3.55 & & 3.58 & 3.43 & 3.47 & 3.43 & 3.32 & 3.37 & 3.37 & 3.35 & 3.42 & $-3.8 \%$ \\
\hline $\mathrm{ZrO} 2$ & 0.71 & & 0.75 & 0.65 & 0.65 & 0.62 & 0.60 & 0.63 & 0.65 & 0.65 & 0.65 & $-8.5 \%$ \\
\hline \begin{tabular}{|l|} 
Totals \\
\end{tabular} & 100.12 & & 98.69 & 98.39 & 99.56 & 99.14 & 98.47 & 98.49 & 98.96 & 100.03 & 98.97 & \\
\hline
\end{tabular}

$\mathrm{Cl}$ and $\mathrm{F}$ were not analyzed.

[CCIM Test Dec2010 Results 16Sept1.xlsx]SRNL glass results

The oxide compositions were normalized to elemental bases in Table 7-2, for use along with the elemental compositions of the input starting glass and melter feed in elemental mass balance calculations.

\subsection{Product Glass REDOX Ratios and Density}

Table 7-3 shows the product glass REDOX ratios and density measurements. The iron is mainly in the fully oxidized $\mathrm{Fe}^{+3}$ state, which is to be expected considering the use of the air bubbler during the test. Three of the glass samples had non-detectable levels of $\mathrm{Fe}^{+2}$. The average $\mathrm{Fe}^{+2} / \mathrm{Fe}_{\text {total }}$ ratio was 0.08 . The glass density was consistent out to three places at an average of $2.80 \mathrm{~g} / \mathrm{cc}$. 
Table 7-2. Elemental composition of the product glasses.

\begin{tabular}{|c|c|c|c|c|c|c|c|c|c|c|c|c|c|c|c|c|c|c|c|}
\hline & \multirow{2}{*}{\multicolumn{4}{|c|}{$\begin{array}{c}\text { Input stream } \\
\text { compositions, wt } \%\end{array}$}} & \multicolumn{15}{|c|}{ Output stream composition, wt $\%$} \\
\hline & & & & & \multicolumn{12}{|c|}{ Glass drains } & \multirow{2}{*}{$\begin{array}{c}\text { Final } \\
\text { mined-out } \\
\text { glass } \\
\end{array}$} & \multirow{2}{*}{\multicolumn{2}{|c|}{$\begin{array}{c}\text { Average } \\
\text { glass } \\
\text { product }\end{array}$}} \\
\hline & & $\begin{array}{l}\text { Starting } \\
\text { glass }\end{array}$ & & $\begin{array}{l}\text { Melter } \\
\text { feed }\end{array}$ & & 1 & & 3 & & 4 & & 5 & & 8 & & 9 & & & \\
\hline Sample number & & $1031 \mathrm{~A}$ & & 1044 & & 1045 & & 1053 & & $1056 \mathrm{~B}$ & & 1058B & & 1069B & & 1073B & 1074B & & --- \\
\hline \multicolumn{20}{|l|}{ Cations, wt \% } \\
\hline $\mathrm{Al}$ & & 6.72 & & 2.80 & & 6.89 & & 6.95 & & 6.93 & & 6.90 & & 7.11 & & 7.03 & 7.17 & & 6.96 \\
\hline B & $<$ & 0.03 & $<$ & 0.06 & $<$ & 0.03 & $<$ & 0.03 & $<$ & 0.03 & $<$ & 0.03 & $<$ & 0.03 & $<$ & 0.03 & 0.03 & $<$ & 0.03 \\
\hline $\mathrm{Bi}$ & & 1.60 & & 0.62 & & 1.55 & & 1.57 & & 1.54 & & 1.54 & & 1.60 & & 1.61 & 1.68 & & 1.59 \\
\hline $\mathrm{Ca}$ & & 0.79 & & 0.31 & & 0.79 & & 0.76 & & 0.77 & & 0.78 & & 0.79 & & 0.79 & 0.79 & & 0.78 \\
\hline $\mathrm{Cl}$ & & -- & $<$ & 0.01 & & -- & & -- & & -- & & -- & & -- & & -- & -- & & -- \\
\hline $\mathrm{Cr}$ & & 1.70 & & 0.73 & & 1.51 & & 1.55 & & 1.55 & & 1.55 & & 1.38 & & 1.55 & 1.43 & & 1.53 \\
\hline Cs & & 0.13 & & -- & & 0.12 & & 0.16 & & 0.13 & & 0.12 & & 0.12 & & 0.12 & 0.13 & & 0.13 \\
\hline $\mathrm{F}$ & & -- & $<$ & 0.01 & & -- & & -- & & -- & & -- & & -- & & -- & -- & & -- \\
\hline $\mathrm{Fe}$ & & 5.18 & & 1.95 & & 5.04 & & 5.02 & & 5.06 & & 4.96 & & 4.90 & & 4.90 & 4.98 & & 5.01 \\
\hline I & $<$ & 0.10 & & -- & $<$ & 0.10 & $<$ & 0.10 & $<$ & 0.10 & $<$ & 0.10 & $<$ & 0.10 & $<$ & 0.10 & 0.10 & $<$ & 0.10 \\
\hline K & & 0.70 & & 0.38 & & 0.75 & & 0.74 & & 0.78 & & 0.77 & & 0.77 & & 0.77 & 0.81 & & 0.76 \\
\hline $\mathrm{La}$ & & 0.59 & & 0.22 & & 0.50 & & 0.50 & & 0.48 & & 0.49 & & 0.51 & & 0.51 & 0.51 & & 0.51 \\
\hline $\mathrm{Na}$ & & 14.37 & & 7.81 & & 14.57 & & 14.67 & & 14.77 & & 14.77 & & 14.62 & & 14.97 & 14.93 & & 14.71 \\
\hline $\mathrm{P}$ & & 16.94 & & 6.78 & & 17.09 & & 17.45 & & 17.25 & & 17.14 & & 17.29 & & 17.25 & 17.55 & & 17.24 \\
\hline $\mathrm{Re}$ & & 0.02 & & -- & & 0.01 & & 0.01 & & 0.01 & & 0.01 & & 0.01 & & 0.01 & 0.01 & & 0.01 \\
\hline $\mathrm{S}$ & & 1.41 & & 0.92 & & 1.33 & & 1.41 & & 1.41 & & 1.41 & & 1.23 & & 1.19 & 1.25 & & 1.33 \\
\hline $\mathrm{Si}$ & & 2.79 & & 1.13 & & 2.71 & & 2.63 & & 2.61 & & 2.57 & & 2.60 & & 2.64 & 2.63 & & 2.65 \\
\hline $\mathrm{Zn}$ & & 2.88 & & 1.01 & & 2.76 & & 2.79 & & 2.76 & & 2.67 & & 2.71 & & 2.71 & 2.69 & & 2.74 \\
\hline $\mathrm{Zr}$ & & 0.56 & & 0.13 & & 0.48 & & 0.48 & & 0.46 & & 0.44 & & 0.47 & & 0.48 & 0.48 & & 0.48 \\
\hline Total wt $\%$ & & 56.50 & & 24.87 & & 56.22 & & 56.82 & & 56.64 & & 56.25 & & 56.24 & & 56.66 & 57.17 & & 56.56 \\
\hline Anions, wt \% & & & & & & & & & & [CCIN & M T & est Dec201 & & Results $16 \mathrm{~S}$ & 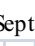 & xlsx]com & np. of glass san & p & les element \\
\hline Chloride & & -- & & 0.010 & & & & & & & & & & & & & & & \\
\hline Oxalate & & -- & & 0.168 & & & & & & & & & & & & & & & \\
\hline Sulfate & & -- & & 2.845 & & & & & & & & & & & & & & & \\
\hline Phosphate & & -- & & -- & & & & & & & & & & & & & & & \\
\hline
\end{tabular}

Table 7-3. Product glass REDOX ratios and density.

\begin{tabular}{|c|c|c|c|c|c|c|c|c|c|c|c|c|}
\hline \multirow[b]{3}{*}{ Oxide } & \multirow[b]{3}{*}{$\begin{array}{c}\text { EA } \\
\text { glass }\end{array}$} & \multicolumn{11}{|c|}{ Sample } \\
\hline & & \multirow{2}{*}{$\begin{array}{c}1031 \mathrm{~A} \\
\text { starter } \\
\text { glass }\end{array}$} & \multicolumn{2}{|r|}{1045} & 1053 & \multicolumn{2}{|c|}{$1056 \mathrm{~B}$} & $1058 \mathrm{~B}$ & 1069B & $1073 \mathrm{~B}$ & $1074 \mathrm{~A}$ & \multirow[b]{2}{*}{ Averages } \\
\hline & & & \multicolumn{2}{|c|}{ cup 1} & cup 3 & \multicolumn{2}{|c|}{ cup 4} & cup 5 & \multirow[t]{2}{*}{ cup 8} & cup 9 & $\begin{array}{c}\text { mined } \\
\text { contents }\end{array}$ & \\
\hline \multicolumn{2}{|c|}{ Iron Redox ratios } & & & & & & & & & & & \\
\hline $\mathrm{Fe}^{+2}$ & 0.07 & 0.02 & $<$ & 0.01 & 0.01 & $<$ & 0.01 & 0.01 & 0.02 & 0.02 & 0.02 & 0.02 \\
\hline $\mathrm{Fe}^{+3}$ & 0.28 & 0.21 & & 0.27 & 0.28 & & 0.23 & 0.25 & 0.23 & 0.2 & 0.22 & 0.24 \\
\hline $\mathrm{Fe}_{\text {total }}$ & 0.35 & 0.22 & & 0.27 & 0.29 & & 0.23 & 0.25 & 0.26 & 0.22 & 0.24 & 0.25 \\
\hline $\mathrm{Fe}^{+2} / \mathrm{Fe}^{+3}$ & 0.23 & 0.08 & \multicolumn{2}{|c|}{ All Fe ${ }^{+3}$} & 0.05 & & $1 \mathrm{Fe}^{+3}$ & All Fe ${ }^{+3}$ & 0.10 & 0.1 & 0.1 & 0.09 \\
\hline $\mathrm{Fe}^{+2} / \mathrm{Fe}_{\text {total }}$ & 0.19 & 0.07 & \multicolumn{2}{|c|}{ All Fe ${ }^{+3}$} & 0.05 & & $1 \mathrm{Fe}^{+3}$ & All Fe ${ }^{+3}$ & 0.09 & 0.09 & 0.09 & 0.08 \\
\hline \multicolumn{2}{|c|}{ Density (g/cc) } & 2.8522 & & .7960 & 2.7860 & & .7986 & 2.7906 & 2.7826 & 2.7863 & 2.7922 & 2.7980 \\
\hline
\end{tabular}




\subsection{Product Glass Durability}

Table 7-4 summarizes the PCT results for the product glasses. The normalized release rates for Na and Si are within the DOE limit for LAW. The normalized release rate for B exceeds the DOE limit; but the concentration of $\mathrm{B}$ is very low in this product glass because $\mathrm{B}$ is present in only trace amounts in the waste simulant, and is not a component of the glass forming chemicals; so the B normalized mass release rate is not a good indicator of durability for this glass.

Table 7-4. PCT results for the product glasses.

\begin{tabular}{|c|c|c|c|c|c|c|c|c|c|c|c|c|c|c|c|c|c|c|}
\hline \multirow[b]{3}{*}{ Oxide } & \multicolumn{17}{|c|}{ Normalized mass release, $\mathrm{g} / \mathrm{L}$} & \multirow[b]{3}{*}{$\begin{array}{c}\text { Within } \\
\text { limit? }\end{array}$} \\
\hline & \multirow{2}{*}{\multicolumn{2}{|c|}{$\begin{array}{c}1031 \mathrm{~A} \\
\text { starter } \\
\text { glass }\end{array}$}} & \multicolumn{2}{|r|}{1045} & \multicolumn{2}{|c|}{1053} & \multicolumn{2}{|c|}{ 1056B } & \multicolumn{2}{|c|}{$1058 \mathrm{~B}$} & \multicolumn{2}{|c|}{ 1069B } & \multicolumn{2}{|c|}{ 1073B } & \multicolumn{2}{|c|}{$1074 \mathrm{~A}$} & \multirow[b]{2}{*}{$\begin{array}{l}\text { DOE limit } \\
\text { for LAW }\end{array}$} & \\
\hline & & & \multicolumn{2}{|c|}{ cup 1} & \multicolumn{2}{|c|}{ cup 3} & \multicolumn{2}{|c|}{ cup 4} & \multicolumn{2}{|c|}{ cup 5} & \multicolumn{2}{|c|}{$\operatorname{cup} 8$} & \multicolumn{2}{|c|}{ cup 9} & \multicolumn{2}{|c|}{$\begin{array}{c}\text { mined } \\
\text { contents }\end{array}$} & & \\
\hline \multicolumn{19}{|c|}{ As received (fast-cooled) results } \\
\hline Al & & 0.61 & & 0.58 & & 0.55 & & 0.56 & & 0.58 & & 0.55 & & 0.56 & & 0.73 & -- & - \\
\hline B & & 10.70 & & 7.58 & & 6.71 & & 9.21 & & 5.07 & & 5.78 & & 6.91 & & 7.61 & 4 & Note 1 \\
\hline $\mathrm{Cr}$ & $<$ & DL & $<$ & DL & $<$ & DL & $<$ & DL & $<$ & DL & $<$ & DL & $<$ & DL & $<$ & DL & -- & -- \\
\hline $\mathrm{Fe}$ & & 0.00 & & 0.01 & & 0.01 & & 0.02 & & 0.02 & & 0.00 & $<1$ & DL & & 0.01 & -- & -- \\
\hline $\mathrm{Na}$ & & 1.34 & & 1.64 & & 1.68 & & 1.64 & & 1.68 & & 1.65 & & 1.70 & & 1.45 & 4 & $\mathrm{Y}$ \\
\hline $\mathrm{P}$ & & 0.60 & & 0.79 & & 0.84 & & 0.77 & & 0.80 & & 0.82 & & 0.86 & & 0.66 & -- & -- \\
\hline $\mathrm{S}$ & $<$ & DL & $<$ & DL & & 1.02 & & 1.18 & & 1.15 & $<$ & DL & $<$ & DL & $<$ & DL & -- & -- \\
\hline $\mathrm{Si}$ & & 0.91 & & 0.68 & & 0.64 & & 0.69 & & 0.68 & & 0.59 & & 0.61 & & 0.92 & 4 & $\mathrm{Y}$ \\
\hline \multicolumn{19}{|c|}{ CCC results } \\
\hline Al & & 0.77 & & 1.09 & & 0.75 & & 0.74 & & 0.70 & & 0.81 & & 0.73 & & 0.84 & -- & - \\
\hline B & & 6.67 & & 8.10 & & 6.73 & & 5.88 & & 8.88 & & 7.38 & & 6.45 & & 6.66 & 4 & Note 1 \\
\hline $\mathrm{Cr}$ & $<$ & DL & $<$ & DL & $<$ & DL & $<$ & DL & $<$ & DL & $<$ & DL & $<$ & DL & $<$ & DL & -- & -- \\
\hline $\mathrm{Fe}$ & $<$ & DL & $<$ & DL & $<$ & DL & $<$ & DL & $<$ & DL & $<$ & DL & & 0.00 & $<$ & DL & -- & -- \\
\hline $\mathrm{Na}$ & & 1.51 & & 1.57 & & 1.50 & & 1.49 & & 1.49 & & 1.65 & & 1.47 & & 1.70 & 4 & $\mathrm{Y}$ \\
\hline $\mathrm{P}$ & & 0.60 & & 0.65 & & 0.59 & & 0.59 & & 0.56 & & 0.66 & & 0.61 & & 0.69 & -- & -- \\
\hline S & & 1.05 & & 1.53 & & 1.20 & & 1.34 & & 1.52 & & 1.47 & & 1.18 & & 1.47 & -- & -- \\
\hline $\mathrm{Si}$ & & 1.09 & & 1.06 & & 1.01 & & 1.03 & & 0.98 & & 0.98 & & 0.95 & & 1.02 & 4 & $\mathrm{Y}$ \\
\hline
\end{tabular}

\begin{tabular}{|l|r|r|r|r|r|r|r|r|r|r|}
\hline$\%$ difference, CCC results compared to as-received results & & & \\
\hline $\mathrm{Al}$ & $26 \%$ & $88 \%$ & $36 \%$ & $32 \%$ & $21 \%$ & $47 \%$ & $30 \%$ & $15 \%$ \\
$\mathrm{~B}$ & $-38 \%$ & $7 \%$ & $0 \%$ & $-36 \%$ & $75 \%$ & $28 \%$ & $-7 \%$ & $-12 \%$ \\
$\mathrm{Cr}$ & -- & -- & -- & -- & -- & - & -- & -- \\
$\mathrm{Fe}$ & -- & -- & -- & - & -- & - & -- & -- \\
$\mathrm{Na}$ & $13 \%$ & $-4 \%$ & $-11 \%$ & $-9 \%$ & $-11 \%$ & $0 \%$ & $-14 \%$ & $17 \%$ \\
$\mathrm{P}$ & $0 \%$ & $-18 \%$ & $-30 \%$ & $-23 \%$ & $-30 \%$ & $-20 \%$ & $-29 \%$ & $5 \%$ \\
$\mathrm{~S}$ & -- & -- & $18 \%$ & $14 \%$ & $32 \%$ & -- & -- & -- \\
$\mathrm{Si}$ & $20 \%$ & $56 \%$ & $58 \%$ & $49 \%$ & $44 \%$ & $66 \%$ & $56 \%$ & $11 \%$ \\
\hline
\end{tabular}

Note 1: The concentration of B is very low in this product glass because B is present in only trace amounts in the waste simulant, and is not a component of the glass forming chemicals; so the B normalized mass release rate is not a good indicator of durability for this glass.

[CCIM T est Dec2010 Results 16Sept1.xlsx]SRNL glass results

Table 7-5 shows the VHT results from MO-SCI Corporation. While the CCC VHT corrosion rate for the CCC samples was higher than for the as-received samples, the corrosion rates for both the as-received and the CCC samples were less than the DOE limit for LAW. 
Table 7-5. VHT corrosion rates for product glass samples.

\begin{tabular}{|l|c|c|c|}
\hline \multirow{2}{*}{ MS26AZ102F-2 } & \multicolumn{3}{|c|}{ VHT Corrosion Rate $\left(\mathrm{g} / \mathrm{m}^{2} /\right.$ day) } \\
\cline { 2 - 4 } CCIM Glass & As-received & CCC & $\begin{array}{c}\text { DOE Limit } \\
\text { for LAW }\end{array}$ \\
\hline CCIM-121510-1650 Cup 5 & 10.1 & 37.1 & \\
CCIM-121610-0830 Cup 9 & 15.0 & $\begin{array}{c}\text { Not enough for } \\
\text { CCC }\end{array}$ & 50 \\
CCIM-121910-1222 Final contents & 15.6 & 22.6 & \\
\hline
\end{tabular}

[CCIM Test Dec2010 Results 13Sept current .xlsx]MO-SCI glass results

\subsection{Product Glass Crystallinity Results}

XRD analyses were performed at PNNL on as-received product glass samples. The XRD patterns for these samples are shown in Figures 7-3 through 7-11. The results show that the following crystalline compounds were detected, in small amounts of crystalline phases in the glass:

- Larger relative amounts: $\mathrm{CaF}_{2}$

- Lesser relative amounts: $\mathrm{Cr}_{2} \mathrm{O}_{3}$, chromium iron oxide, nosean, sodium phosphate, sodium iron oxide, calcium phosphate, and sodalite.

Two of the cup samples, that were fast-cooled but not fast-quenched by fritting, had more crystalline phases. This was especially true for the drain 4 sample. 


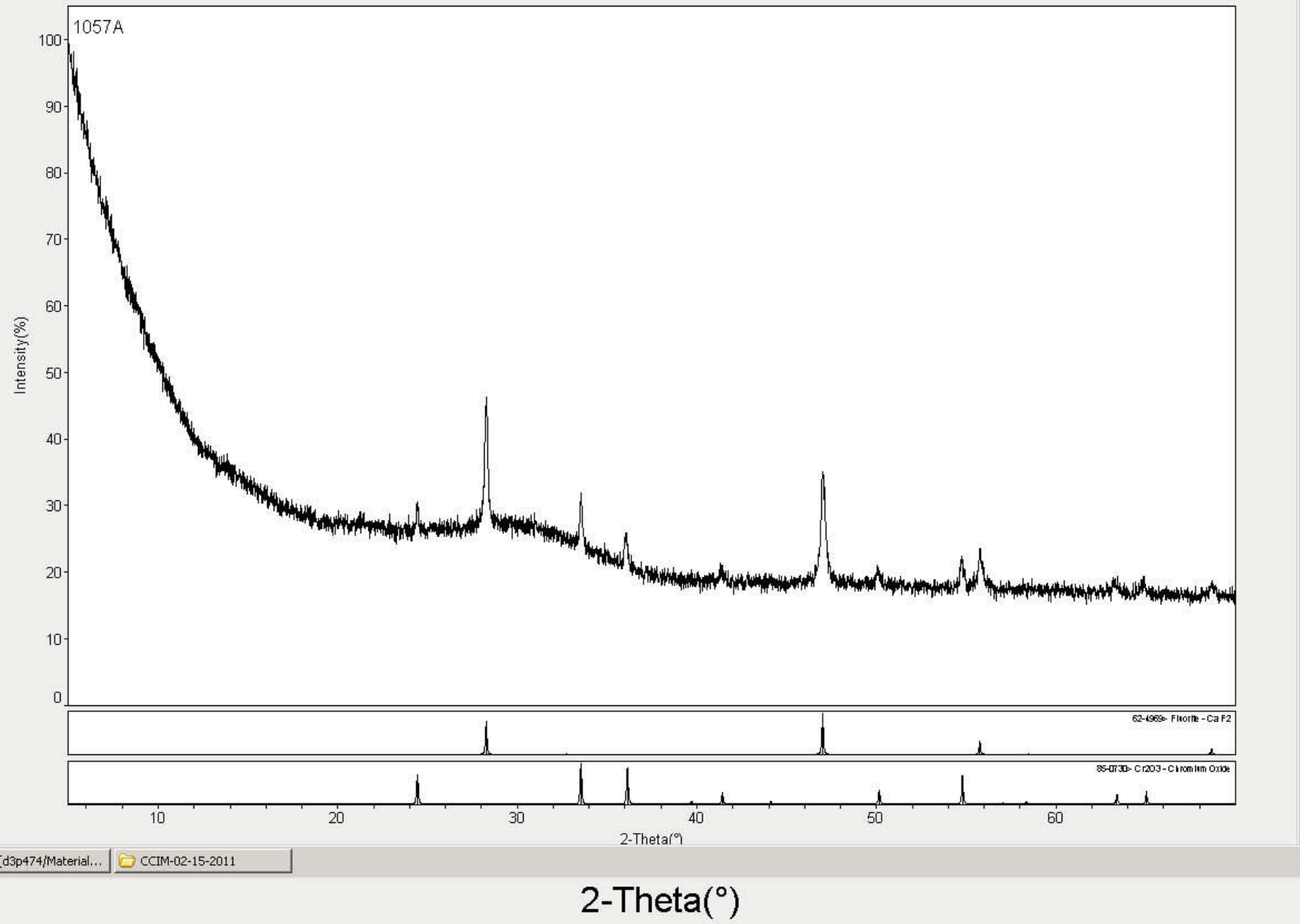

Figure 7-3. XRD scan for sample 1057A, drain 3 frit sample (fast-quenched glass). 


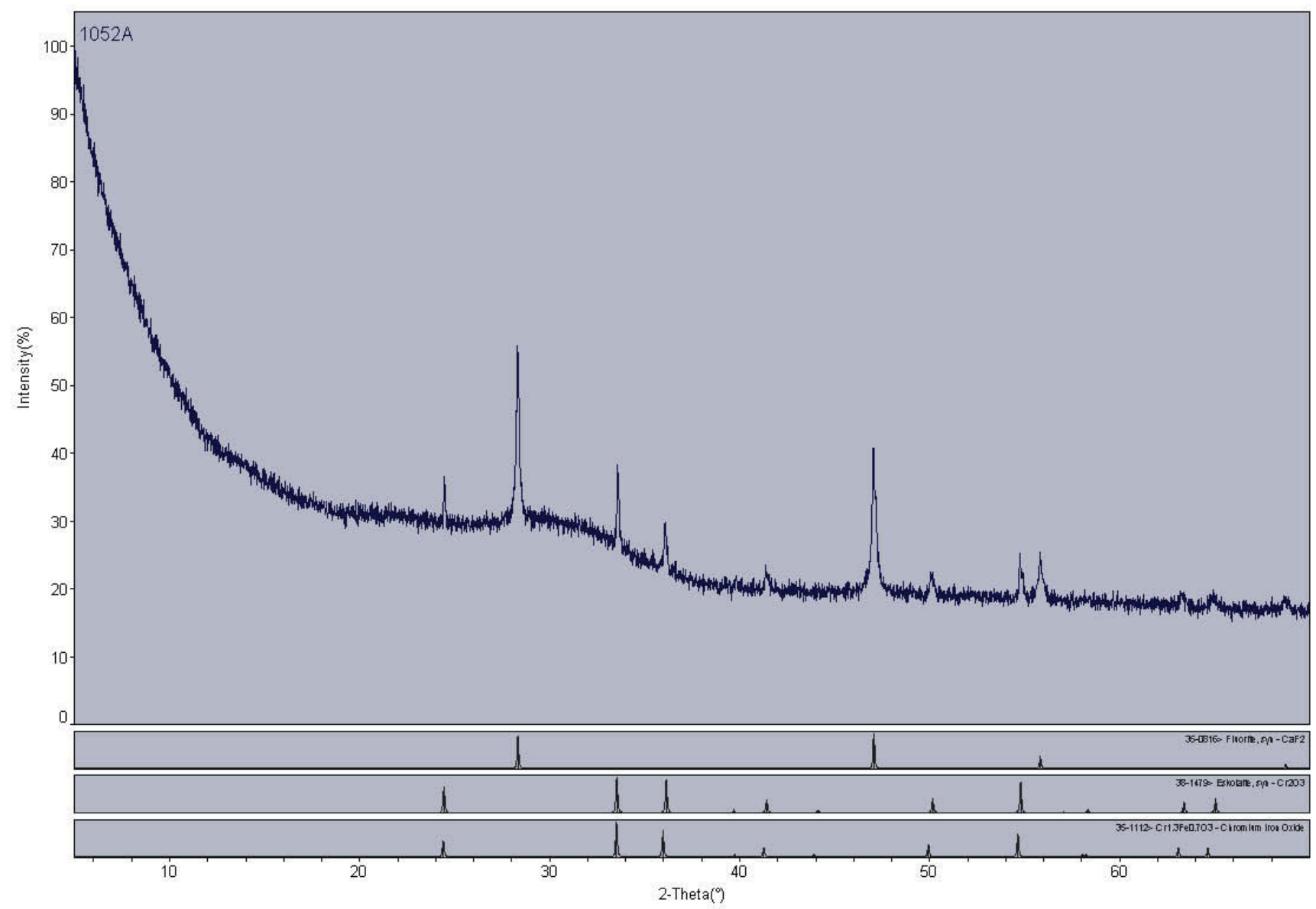

Figure 7-4. XRD scan for sample 1052A, drain 4 fritted sample (fast-quenched glass). 


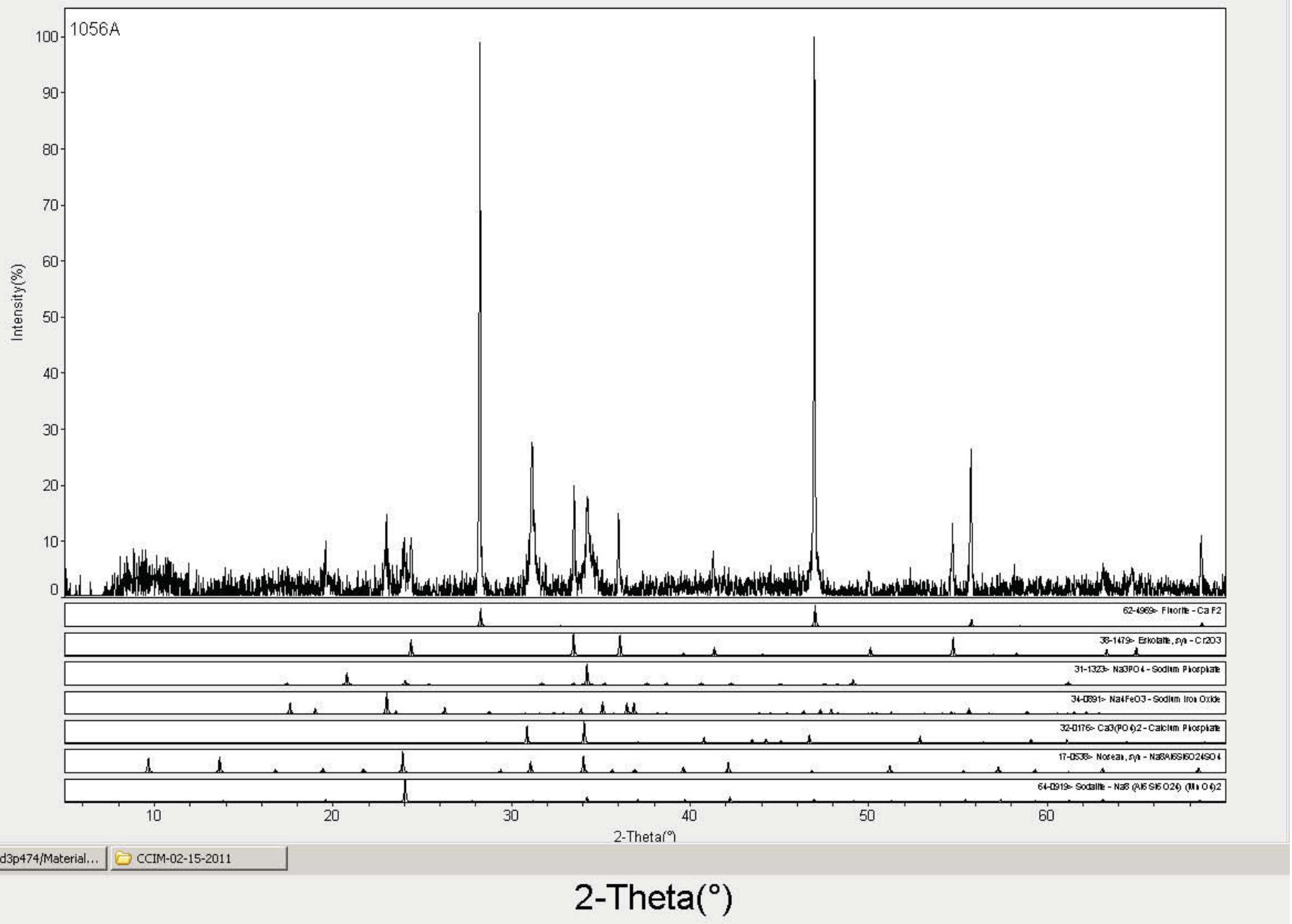

Figure 7-5. XRD scan for sample 1056A, drain 4 cup sample (fast-cooled but not quenched glass). 


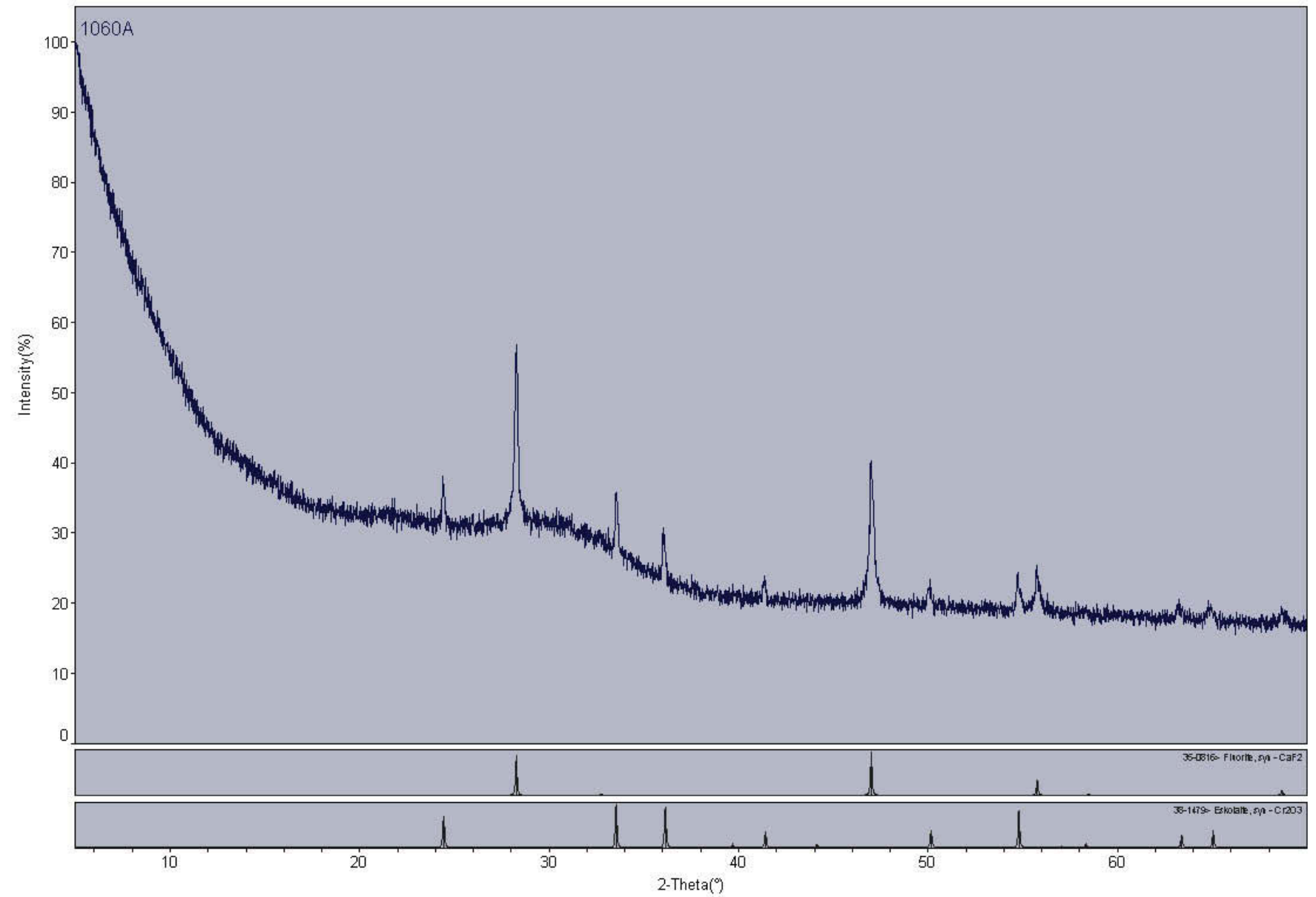

Figure 7-6. XRD scan for sample 1060A, drain 5 fritted sample (fast-quenched glass) 


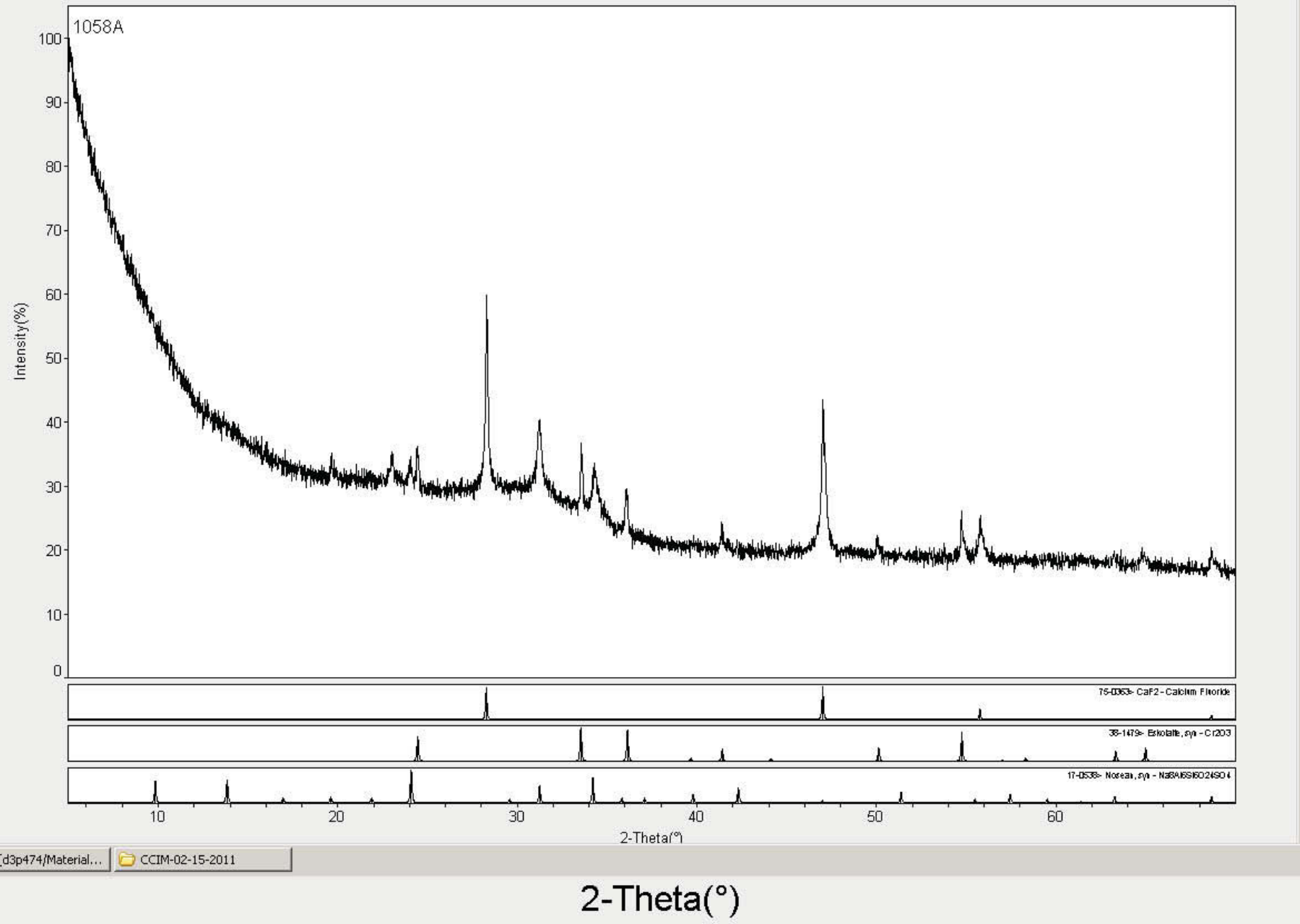

Figure 7-7. XRD scan for sample 1058A, drain 5 cup sample (fast-cooled but not quenched glass). 


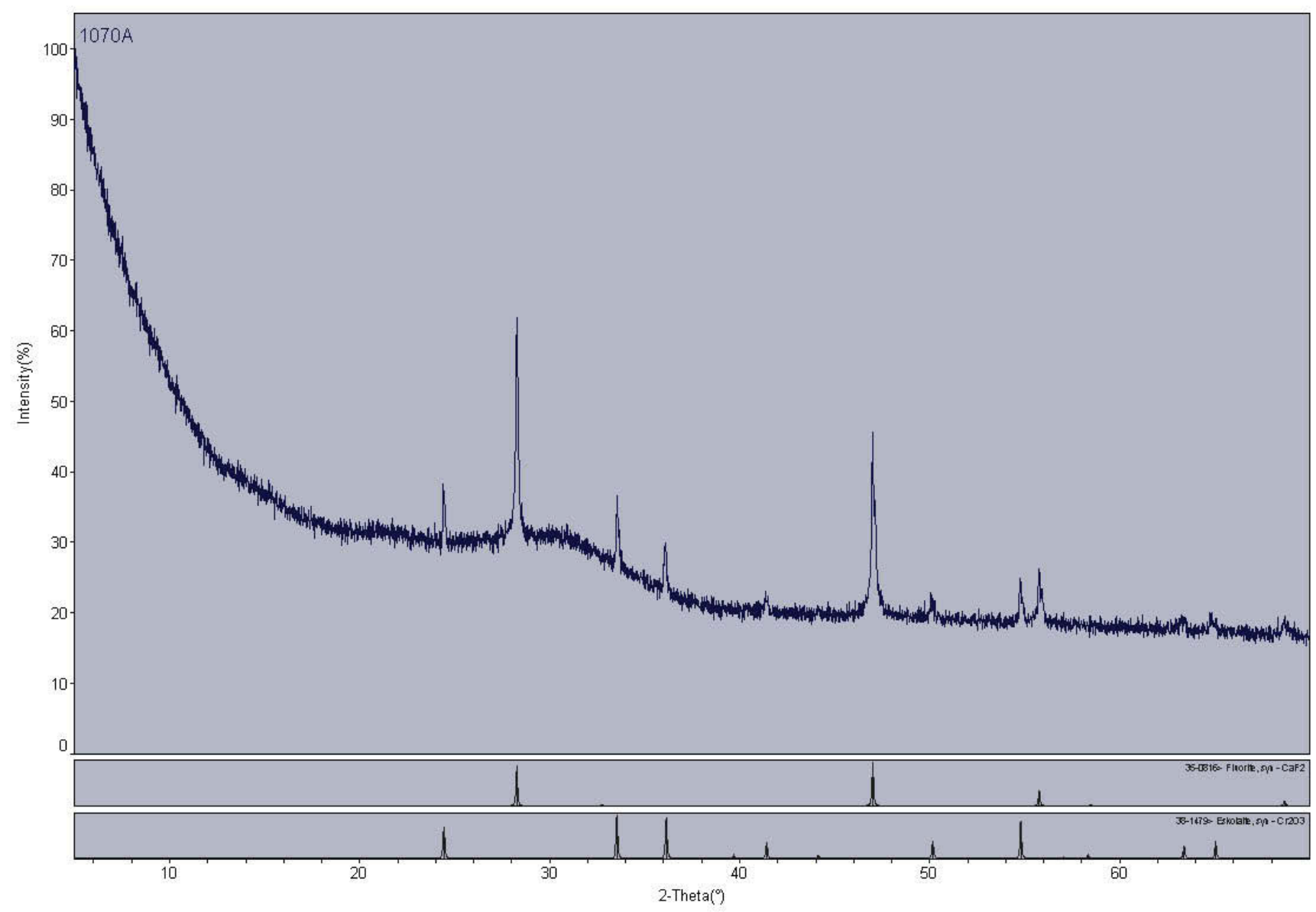

Figure 7-8. XRD scan for sample 1070A, drain 8 fritted sample (fast-quenched glass). 


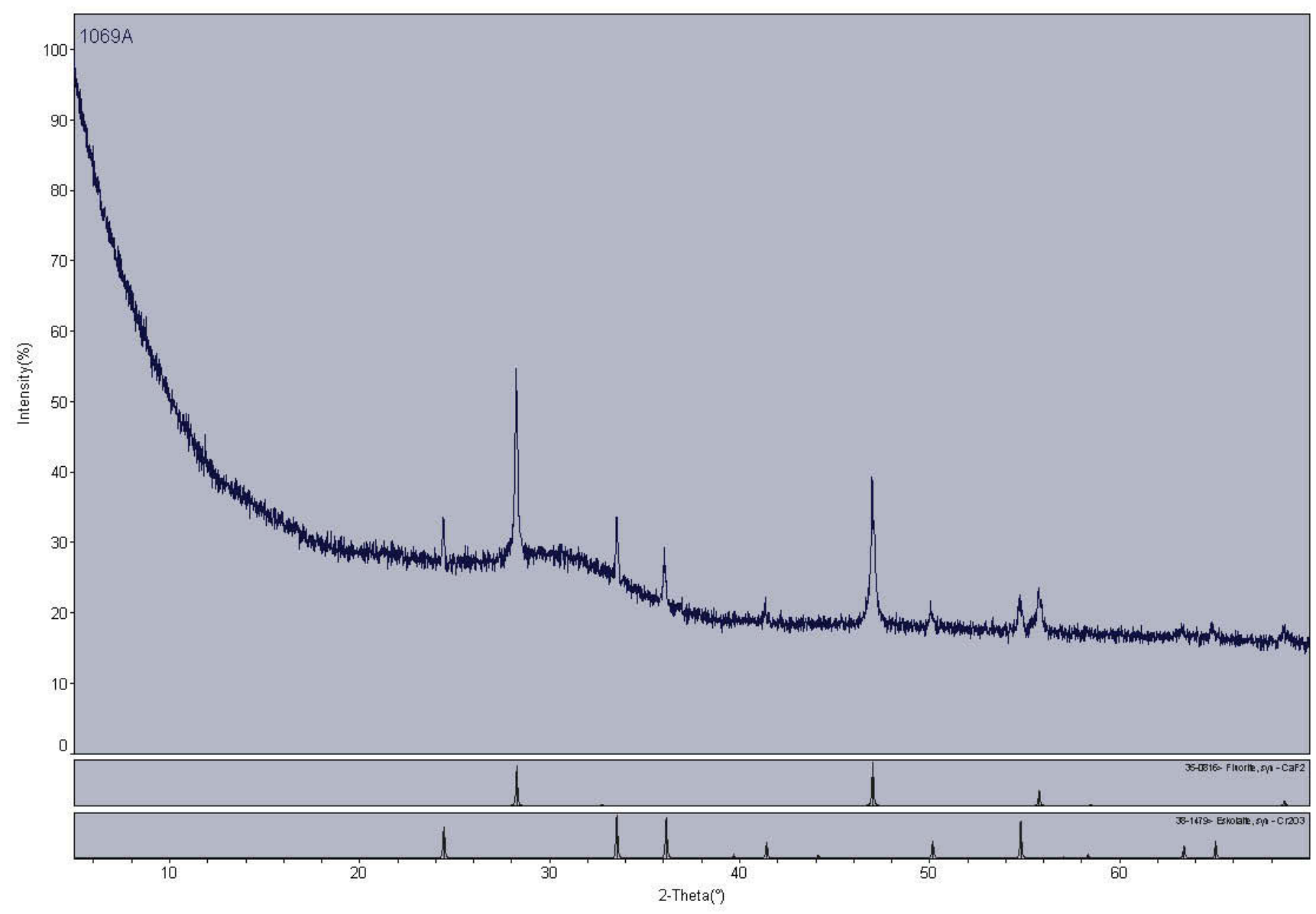

Figure 7-9. XRD scan for sample 1069A, drain 8 cup sample (fast-cooled but not quenched glass). 


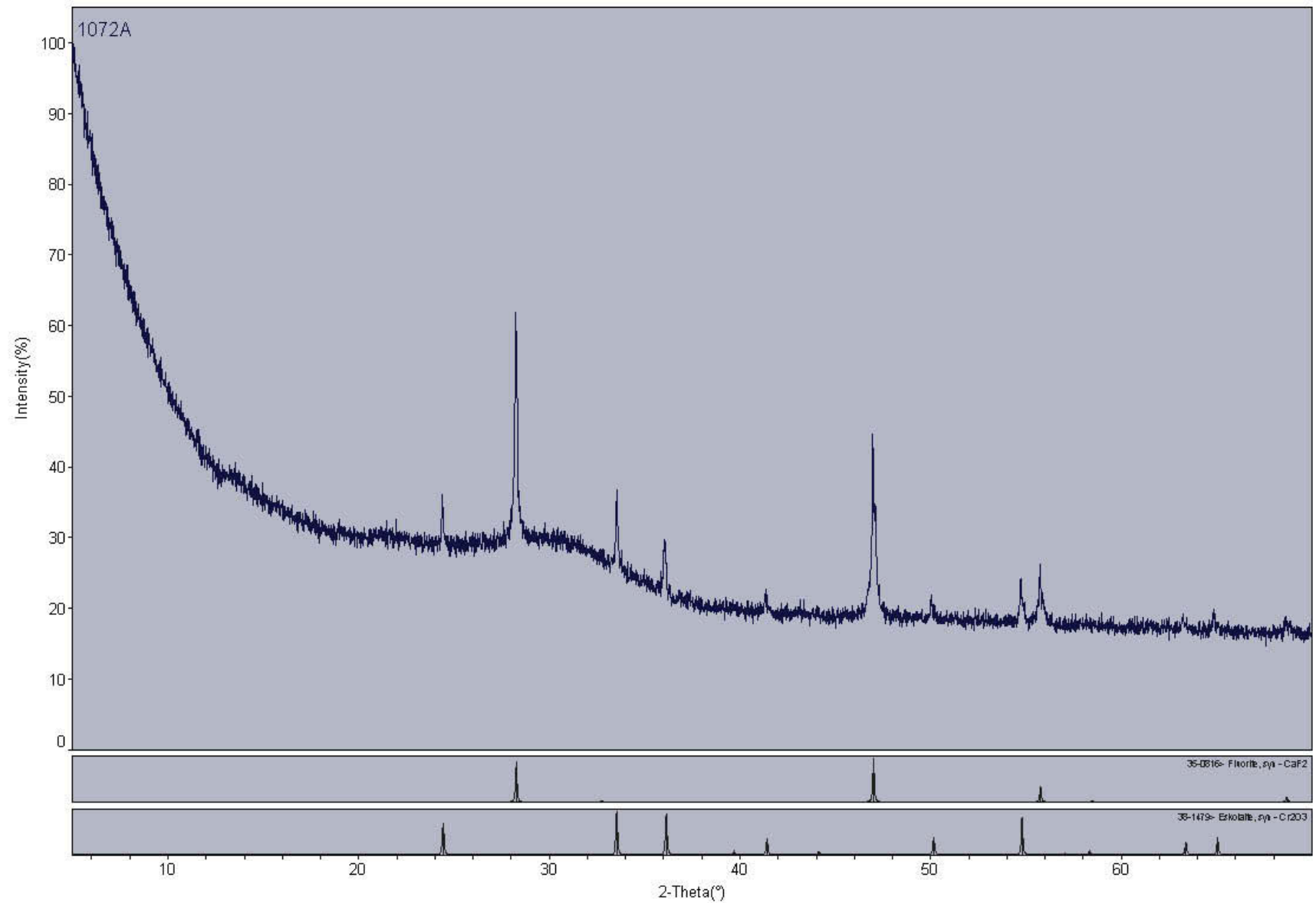

Figure 7-10. XRD scan for sample 1072A, drain 9 fritted sample (fast-quenched glass). 


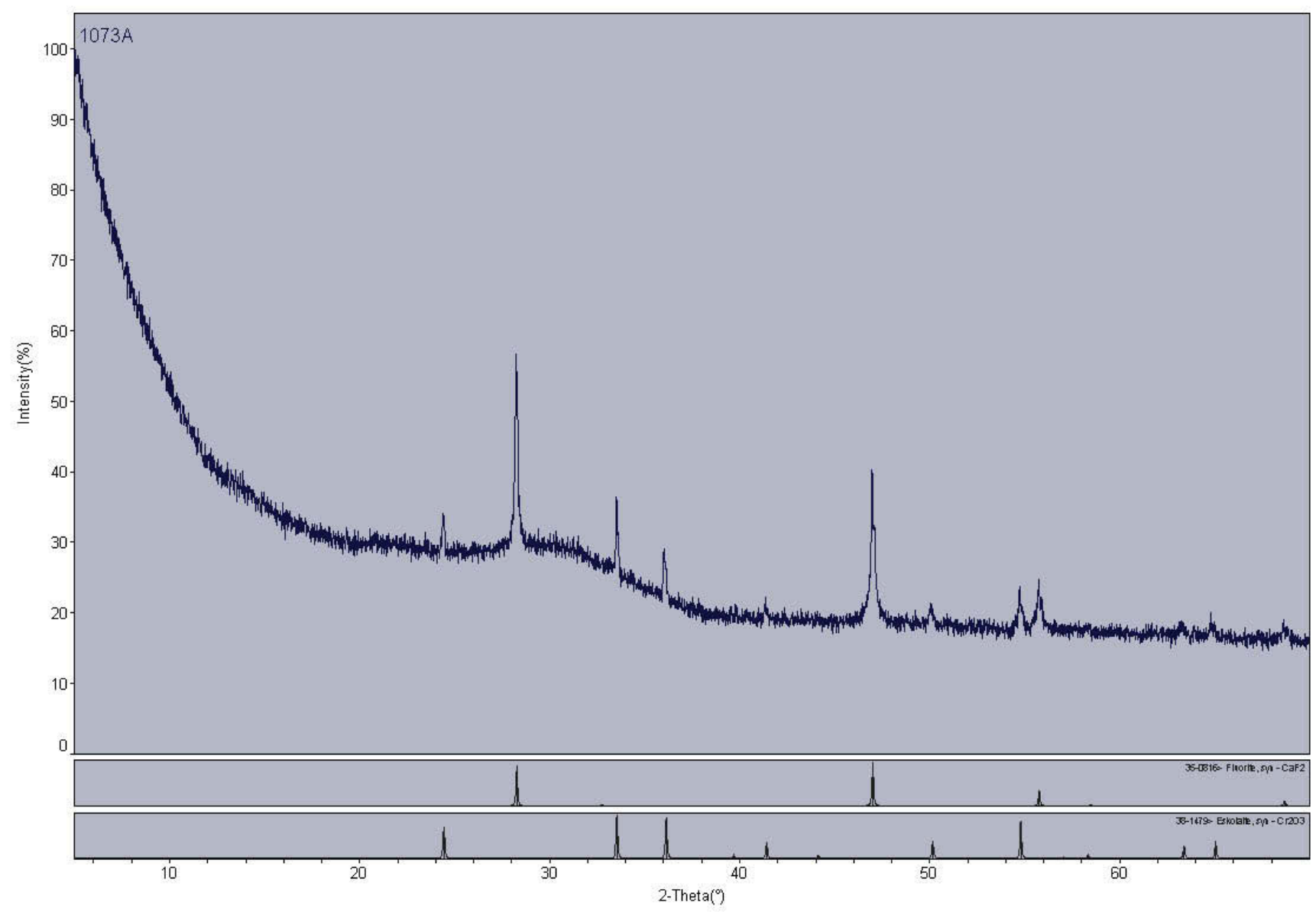

Figure 7-11. XRD scan for sample 1073A, drain 9 cup sample (fast-cooled but not quenched glass). 


\section{Mass Balance and Partitioning Results}

Mass balances were performed using composition analyses, process rates, and masses of the input and output streams. The mass balances were determined using the compositions and masses of the simulant feed, the glass product drained from the melter during operation and removed from the crucible after shutdown, and the results of the off-gas PM and metals measurements.

While more volatile metals are more prone to volatilize from the melter at the elevated melter temperatures, all metals in the feed will evolve from the melter in dust entrained from the cold cap and in fume volatilized and physically ejected (through bubbling and entrainment in gas that passes through the cold cap and the melt surface). Physical and thermodynamic mechanisms that result in evolution of feed material into the off-gas that would otherwise be incorporated into the glass product include (a) volatilization at elevated melt temperatures, with or without subsequent condensation into "fume" particles, (b) physical entrainment in the melter off-gas of dust particles formed in the cold cap as the feed dries, and (c) physical ejection of molten glass aerosols through bubbling of gas in the melt or other turbulence.

Table 8-1 shows the total and elemental mass balances for the test. The composition of glass from drains 2, 6, and 7 were not analyzed, so the composition of the glass from these drains was estimated by averaging the compositions of the preceding and anteceding drains. The elemental masses of each drain were calculated using the compositions and mass of each drain.

The mass balances show that generally good mass balance closure was achieved. Figure 8-1 shows that most of the elements in the feed had mass balance closure (output mass divided by input mass) of 0.8 to 1.2 , a reasonable range considering experimental error. The total mass balance of the glass is even better, at 1.03. Elements that had mass balance closure outside of the 0.8-1.2 range were Re, S, and Zr. The concentrations of $\mathrm{Re}$ and $\mathrm{Zr}$ were relatively small, so experimental errors may have been relatively large compared to the same errors for elements present in larger amounts. The sulfur mass balance closure, at about 0.76 , was just outside of the 0.8 to 1.2 range. The low $\mathrm{S}$ mass balance closure may have been due in part to the ability of S to form various other species that were not detected in the offgas analyses.

Elemental partitioning is shown in Figure 8-2. The partitioning values reported here were calculated by dividing the mass of each element measured in the off-gas PM by the total output mass of that element measured in the off-gas PM and the glass product. This method eliminates potential error in the partitioning calculations that can occur from non-unity mass balance closure of the input and output streams - but it depends on the quality of the product glass and off-gas PM measurements. The alternative methods of partitioning calculations include (a) dividing the elemental mass measured in the off-gas PM by the input mass of that element, and (b) dividing difference of the mass of the element measured in the product glass and the input feed, by the mass of the element in the input feed.

The different partitioning calculations can result in somewhat different values, depending on the degree of mass balance closure. The partitioning of Cs to the offgas PM based on the output masses is shown in Table 8-1 and Figure 8-2 to be 3.9\%. Because the Cs mass balance closure (1.16) is greater than one, the method of calculating Cs partitioning based on the glass and the melter feed cannot be used; the method of calculating the Cs partitioning using the off-gas Cs and input feed Cs measurements results in a relatively close Cs partitioning value of $4.6 \%$. 
Table 8-1. Input and output total and elemental mass balances compositions for the test (part 1).

\begin{tabular}{|c|c|c|c|c|}
\hline & \multicolumn{4}{|c|}{ Input streams } \\
\hline & $\begin{array}{l}\text { Starting } \\
\text { glass }\end{array}$ & & Melter feed & $\begin{array}{c}\text { Total } \\
\text { input } \\
\text { streams }\end{array}$ \\
\hline Sample number & $1031 \mathrm{~A}$ & & 1044 & -- \\
\hline Total input feed, $\mathrm{kg}$ & -- & & 93.43 & -- \\
\hline Glass, $\mathrm{kg}$ & 16.5 & & 41.44 & 57.93 \\
\hline $\mathrm{Al}$ & 1.1 & & 2.6 & 3.7 \\
\hline B & 0.0051 & $<$ & 0.056 & 0.061 \\
\hline $\mathrm{Bi}$ & 0.26 & & 0.58 & 0.85 \\
\hline $\mathrm{Ca}$ & 0.131 & & 0.29 & 0.42 \\
\hline $\mathrm{Cl}$ & -- & $<$ & 0.0093 & -- \\
\hline $\mathrm{Cr}$ & 0.28 & & 0.68 & 0.96 \\
\hline Cs & 0.022 & & 0.045 & 0.067 \\
\hline $\mathrm{F}$ & -- & $<$ & 0.0093 & -- \\
\hline $\mathrm{Fe}$ & 0.85 & & 1.82 & 2.7 \\
\hline $\mathrm{I}$ & 0.0165 & & 0.010 & 0.03 \\
\hline K & 0.115 & & 0.35 & 0.47 \\
\hline $\mathrm{La}$ & 0.097 & & 0.205 & 0.30 \\
\hline $\mathrm{Na}$ & 2.4 & & 7.29 & 9.7 \\
\hline $\mathrm{P}$ & 2.8 & & 6.33 & 9.1 \\
\hline $\mathrm{Re}$ & 0.0025 & & 0.0074 & 0.0099 \\
\hline S & 0.23 & & 0.86 & 1.09 \\
\hline $\mathrm{Si}$ & 0.46 & & 1.06 & 1.52 \\
\hline $\mathrm{Zn}$ & 0.47 & & 0.95 & 1.42 \\
\hline $\mathrm{Zr}$ & 0.09 & & 0.123 & 0.215 \\
\hline Totals & 9.3 & & 23.3 & 32.6 \\
\hline
\end{tabular}

With a mass balance closure less than one (0.76) the calculated S partitioning to the off-gas based on the $\mathrm{S}$ measured in the off-gas solids and the product glass is $10 \%$. Alternatively, an $\mathrm{S}$ partitioning value of $32 \%$ results from using the $\mathrm{S}$ measurements in the product glass and the input feed.

Figure 8-2 illustrates which elements are more volatile - those which partition to the off-gas at a higher rate than the total elemental partitioning of 1.01. These elements are Cs, Re, and S. The calculations indicate that about $36 \%$ of the Re partitioned to the off-gas. Very little of the P $(0.07 \%)$ partitioned to the off-gas. 
Table 8-1. Input and output total and elemental mass balances compositions for the test (continued).

\begin{tabular}{|c|c|c|c|c|c|c|c|c|c|c|c|c|c|c|c|}
\hline & \multicolumn{13}{|c|}{ Output streams } & \multirow{3}{*}{\begin{tabular}{|c|} 
Mass \\
balance \\
closure, \\
out $/$ in \\
\end{tabular}} & \multirow{3}{*}{$\begin{array}{c}\text { Partition } \\
\text { to off- } \\
\text { gas PM, } \\
\%\end{array}$} \\
\hline & \multicolumn{9}{|c|}{ Glass drains } & \multirow{2}{*}{$\begin{array}{c}\text { Final } \\
\text { mined out } \\
\text { glass }\end{array}$} & \multirow{2}{*}{$\begin{array}{l}\text { Total } \\
\text { glass }\end{array}$} & \multirow{2}{*}{$\begin{array}{c}\text { Off-gas } \\
\text { PM }\end{array}$} & \multirow{2}{*}{\begin{tabular}{|c|} 
Total \\
output \\
streams \\
\end{tabular}} & & \\
\hline & 1 & 2 & 3 & 4 & 5 & 6 & 7 & 8 & 9 & & & & & & \\
\hline Sample number & 1045 & -- & 1053 & $1056 \mathrm{~B}$ & $1058 \mathrm{~B}$ & -- & -- & 1069B & $1073 \mathrm{~B}$ & $1074 \mathrm{~A}$ & -- & -- & -- & -- & - \\
\hline Total input feed, $\mathrm{kg}$ & -- & -- & -- & -- & -- & -- & -- & -- & -- & -- & -- & -- & - & -- & - \\
\hline Glass, $\mathrm{kg}$ & 3.12 & 2.583 & 1.34 & 1.73 & 4.31 & 4.82 & 5.455 & 2.61 & 4.87 & 28.38 & 59.20 & 0.185 & 59.38 & 1.03 & $0.31 \%$ \\
\hline $\mathrm{Al}$ & 0.21 & 0.092 & 0.09 & 0.12 & 0.30 & 0.34 & 0.38 & 0.19 & 0.34 & 2.0 & 4.1 & 0.0029 & 4.1 & 1.10 & $0.07 \%$ \\
\hline B & $<0.0010$ & $<0.00041$ & $<\quad 0.0004$ & $<0.00054$ & $<0.0013$ & 0.0015 & $<0.0017$ & 0.0008 & $<0.0015$ & 0.009 & 0.018 & 0.00059 & 0.019 & -- & - \\
\hline $\mathrm{Bi}$ & 0.048 & 0.021 & 0.021 & 0.027 & 0.066 & 0.076 & 0.086 & 0.042 & 0.079 & 0.48 & 0.94 & 0.0020 & 0.94 & 1.11 & $0.22 \%$ \\
\hline $\mathrm{Ca}$ & 0.0245 & 0.0104 & 0.0102 & 0.0133 & 0.034 & 0.038 & 0.043 & 0.0205 & 0.039 & 0.225 & 0.46 & 0.0014 & 0.46 & 1.09 & $0.30 \%$ \\
\hline $\mathrm{Cl}$ & -- & -- & -- & -- & -- & -- & -- & -- & -- & -- & -- & 0.000045 & -- & -- & -- \\
\hline $\mathrm{Cr}$ & 0.047 & 0.020 & 0.021 & 0.027 & 0.067 & 0.071 & 0.080 & 0.036 & 0.075 & 0.41 & 0.85 & 0.00065 & 0.85 & 0.89 & $0.08 \%$ \\
\hline Cs & 0.0038 & 0.0019 & 0.0021 & 0.0023 & 0.0053 & 0.0059 & 0.0067 & 0.0032 & 0.0060 & 0.037 & 0.075 & 0.0031 & 0.078 & 1.16 & $3.93 \%$ \\
\hline $\mathrm{F}$ & -- & -- & -- & -- & -- & -- & -- & -- & -- & -- & -- & 0.000073 & -- & -- & -- \\
\hline $\mathrm{Fe}$ & 0.16 & 0.067 & 0.067 & 0.087 & 0.21 & 0.24 & 0.27 & 0.128 & 0.24 & 1.4 & 2.88 & 0.0070 & 2.9 & 1.08 & $0.24 \%$ \\
\hline I & $<0.0031$ & 0.00134 & $<0.00134$ & $<0.00173$ & $<0.0043$ & 0.0048 & 0.0055 & 0.00261 & 0.0049 & 0.0284 & 0.06 & 0.000008 & 0.058 & -- & - \\
\hline K & 0.023 & 0.0099 & 0.0099 & 0.013 & 0.033 & 0.037 & 0.042 & 0.020 & 0.038 & 0.23 & 0.46 & 0.0019 & 0.46 & 0.98 & $0.42 \%$ \\
\hline $\mathrm{La}$ & 0.016 & 0.0067 & 0.0067 & 0.008 & 0.021 & 0.024 & 0.027 & 0.0133 & 0.025 & 0.145 & 0.29 & 0.00042 & 0.29 & 0.97 & $0.14 \%$ \\
\hline $\mathrm{Na}$ & 0.45 & 0.20 & 0.20 & 0.26 & 0.64 & 0.71 & 0.80 & 0.38 & 0.73 & 4.2 & 8.59 & 0.023 & 8.6 & 0.89 & $0.27 \%$ \\
\hline $\mathrm{P}$ & 0.53 & 0.23 & 0.23 & 0.30 & 0.74 & 0.83 & 0.94 & 0.45 & 0.84 & 5.0 & 10.07 & 0.0074 & 10.1 & 1.10 & $0.07 \%$ \\
\hline $\mathrm{Re}$ & 0.00024 & 0.000103 & 0.000103 & 0.000133 & 0.00033 & 0.00037 & 0.00042 & 0.00020 & 0.00037 & 0.0022 & 0.00 & 0.0025 & 0.0069 & 0.70 & $35.7 \%$ \\
\hline$S$ & 0.041 & 0.018 & 0.019 & 0.024 & 0.061 & 0.064 & 0.072 & 0.032 & 0.058 & 0.35 & 0.74 & 0.08 & 0.83 & 0.76 & $10.0 \%$ \\
\hline $\mathrm{Si}$ & 0.084 & 0.036 & 0.035 & 0.045 & 0.111 & 0.125 & 0.141 & 0.068 & 0.128 & 0.75 & 1.52 & -- & 1.52 & 1.00 & - \\
\hline $\mathrm{Zn}$ & 0.086 & 0.037 & 0.037 & 0.048 & 0.115 & 0.130 & 0.147 & 0.071 & 0.132 & 0.76 & 1.56 & 0.004 & 1.57 & 1.10 & $0.26 \%$ \\
\hline $\mathrm{Zr}$ & 0.0150 & 0.0064 & 0.0064 & 0.0079 & 0.0191 & 0.0219 & 0.0248 & 0.0121 & 0.0234 & 0.137 & 0.27 & 0.0003 & 0.27 & 1.28 & $0.10 \%$ \\
\hline Totals & 1.8 & 0.75 & 0.76 & 0.98 & 2.4 & 2.7 & 3.1 & 1.5 & 2.8 & 16.2 & 32.9 & 0.14 & 33.0 & 1.01 & $0.42 \%$ \\
\hline \multicolumn{16}{|l|}{ Notes: } \\
\hline \multicolumn{16}{|c|}{ 1. Chloride, fluoride, sulfate, and phosphate were not measured in the off-gas. $\mathrm{Cl}$ and $\mathrm{F}$ were not measured in the product glass, so no mass balance was done for $\mathrm{Cl}$ and $\mathrm{F}$. } \\
\hline \multicolumn{16}{|c|}{ 2. Italicized values are calculated values for species not analyzed by the lab. } \\
\hline \multicolumn{16}{|c|}{ 3. "<" values, when summed with other "<" values, or when summed with actual values greater than $10 \mathrm{x}$ the "<" values, are normalized to zero for mass balance calculations. } \\
\hline \multicolumn{16}{|c|}{ 4. Greyed values are for glass drains not analyzed; they are determined by taking a linear average of the preceeding and anteceding values. } \\
\hline \multicolumn{16}{|c|}{ 5. Si cannot be measured in the off-gas, because a glass fiber filter is used to collect the off-gas particulate sample, that is $100 \% \mathrm{SiO}_{2}$, which invalidates the $\mathrm{Si}$ analysis. } \\
\hline 6. Nitrite, nitrate, an & formate we & ere all not dete & ected in the gl & lass products & , and so are & assumed to $\mathrm{p}$ & partition to th & he off-gas (c & or be destroy & yed). & & & & & \\
\hline
\end{tabular}

[CCIM Test Dec2010 Results 16Sept1.xlsx]mass bal 


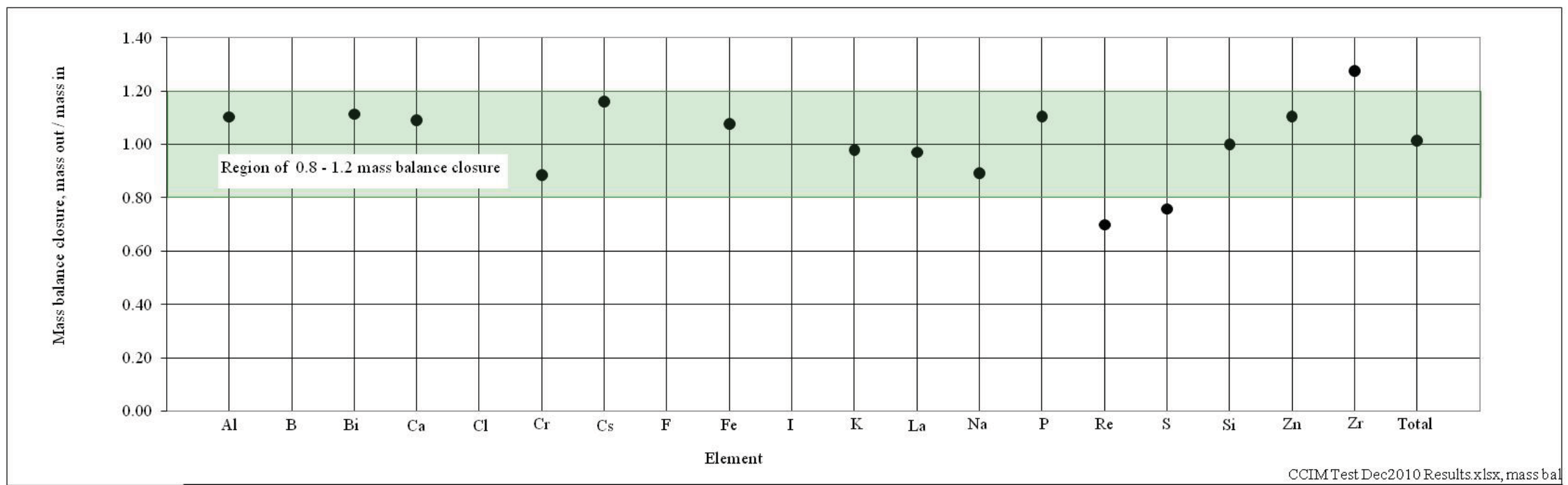

Figure 8-1. Elemental mass balance closure for the test.

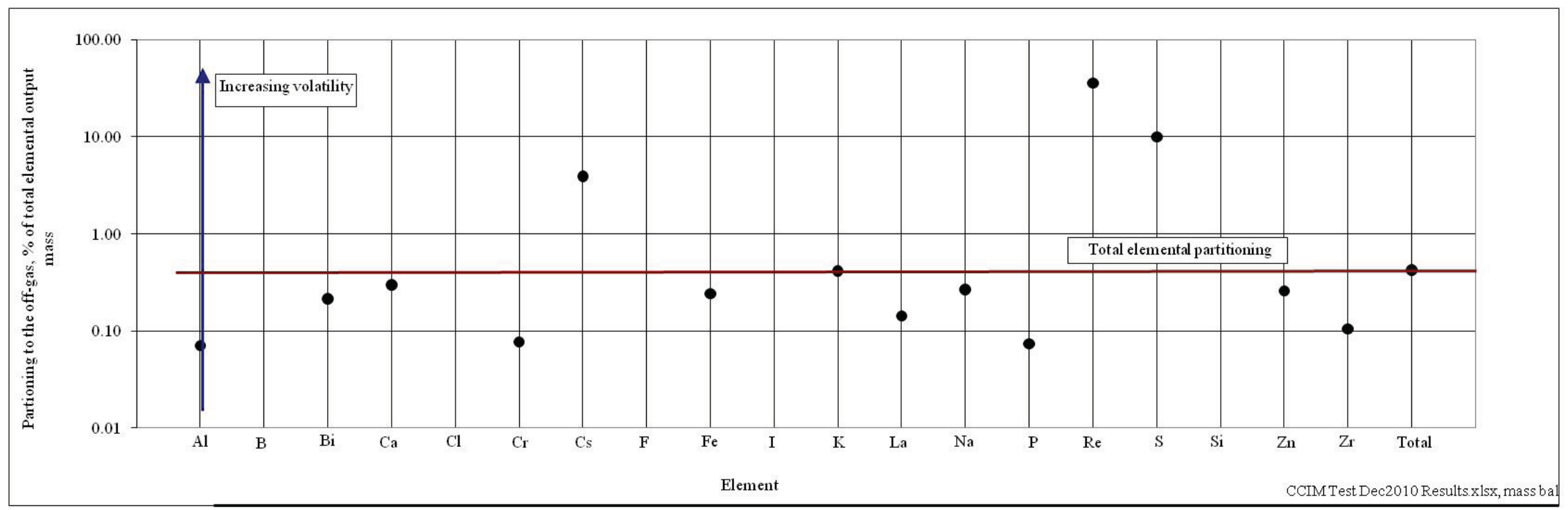

Figure 8-2. Elemental partitioning to off-gas particulate matter for the test. 


\section{CONCLUSIONS}

This CCIM test program shows how work performed by a multi-laboratory, international, and multidisciplinary team can accomplish challenging tasks. This test has indeed shown conditions under which an iron-phosphate glass formulation of a challenging high-S and high-Na Hanford LAW stream can be vitrified in a CCIM. The melting process can be performed at relatively moderate vitrification temperatures below $1,100^{\circ} \mathrm{C}$.

At a waste loading of $26 \%$ waste oxides in the glass, the iron-phosphate glass retained $\mathrm{S}$ at much higher levels in the glass compared to a borosilicate glass waste form, resulting in a potential 4-8 times increase in processing rate for this type of waste stream. The partitioning of feed constituents including glass-forming elements (including $\mathrm{Na}, \mathrm{S}, \mathrm{Fe}$, and $\mathrm{P}$ ), and the partitioning of radionuclide surrogates (Cs and $\mathrm{Re}$ ) are consistent with the moderate melter operating temperature.

The iron-phosphate glass durability meets applicable limits based on PCT and VHT analyses, both for as-received (fast-cooled) glass and for glass re-heated and slowly cooled.

Future iron-phosphate studies might include these possible activities:

- Longer-duration testing in a larger-diameter crucible to demonstrate higher potential feedrates by using freeboard heating, or a larger-diameter crucible with less bridging that occurs in a smallerdiameter crucible

- Additional off-gas analyses to assess such features as in-melter $\mathrm{NO}_{\mathrm{x}}$ destruction and $\mathrm{S}$ speciation

- Potential further increases in waste loading

- Additional S partitioning analyses to better narrow the $10-32 \%$ range of $\mathrm{S}$ partitioning to the offgas observed this test

- Investigation of melt temperature and control methods including more corrosion-resistant thermocouples and models that relate melt temperature to induction power conditions

- Other challenging waste streams.

\section{REFERENCES}

Day 2011

Girold 2008

Hansen 2010a

Hansen 2010b

NAS 2009
Day, Delbert, Richard Brow, Chandra Ray, and Cheol-Woon Kim, "Formulation of Iron Phosphate Glasses with Simulated Hanford LAW for Joule Heated and Cold Crucible Induction Melters (Phosphate Glass Development and Demonstration)," Missouri University of Science and Technology, and MO-SCI Corporation, 30 June 2011.

Girold, C. et al, "Proposed Configuration and Operating Conditions for the INL Demonstration," CEA memo to the ART CCIM Phase II-A participants, 10 September.

Hansen, Erich, personal communication "7M AZ-102 Salt Solution Simulant.pdf” emailed October 18, 2010.

Hansen, Erich, personal communication "Subject: Summary of the Oct. 21 WP4.1.3 telecon, and a few action items" emailed October 26, 2010.

National Academy of Sciences, "Advice on the Department of Energy's Cleanup Technology Roadmap: Gaps and Bridges," ISBN: 0-309-13232-0, Committee on 
Development and Implementation of a Cleanup Technology Roadmap; National Research Council, 2009.

Soelberg 2009 Soelberg, Nick, Jay Roach, Mike Ancho, and John Richardson, "ART CCIM Phase II-A Off-Gas System Evaluation Report,” INL-EXT-09-15711, April 2009.

Soelberg $2010 \quad$ Soelberg, Nick, et al, "Next Generation Bench-Scale Cold Crucible Induction Melter Task Plan," DOE Doc. No. WP-4.1.3-2010-001, INL-EXT2010-18683, July 2010 . 